\title{
The Impact of Refugees on Employment and Wages in Jordan ${ }^{1}$
}

\author{
Belal Fallah, ${ }^{2}$ Caroline Krafft, ${ }^{3}$ and Jackline Wahba $^{4}$
}

\begin{abstract}
Starting in 2011, the Syrian conflict caused a large influx of refugees into Jordan. In 2015, there were an estimated 1.3 million Syrians in a country with just 6.6 million Jordanians. This paper investigates the impact of the Syrian refugee influx on the Jordanian labor market. Panel data from 2010 and 2016 combined with information on where the refugee influx was concentrated allow us to identify the impact of refugees on Jordanians' labor market outcomes. Overall, we find that Jordanians living in areas with a high concentration of refugees have had no worse labor market outcomes than Jordanians with less exposure to the refugee influx.
\end{abstract}

Keywords: Refugees; Labor Markets; Employment; Unemployment; Wages; Jordan

JEL Codes: J21, J31, F22, O15

\footnotetext{
${ }^{1}$ Research supported by the British Academy through the Economic Research Forum (ERF). The authors appreciate the helpful comments of discussant Susan Razzaz and participants in the December 2017 ERF "The Impact of Syrian Refugees Influx on Neighboring Countries" workshop, as well as participants in the University of Minnesota, Department of Applied Economics Development Seminar. The authors would like to thank Caitlyn Keo and Abu Siddique for research assistance.

${ }^{2}$ College of Administrative Sciences and Informatics, Palestine Polytechnic University, Hebron, Palestine. Email: bfallah2000@yahoo.com

${ }^{3}$ Corresponding Author. Department of Economics and Political Science, St. Catherine University, 2004 Randolph Avenue, St. Paul, MN 55105, USA. Email: cgkrafft@stkate.edu

4 Department of Economics, University of Southampton, Southampton, SO171BJ, UK. Email: j.wahba@soton.ac.uk
} 


\section{Introduction}

During the past decade, the number of people forcibly displaced has risen to unprecedented levels. From 2007 to 2017, the number of displaced people rose from 43 million to 69 million (UNHCR 2018a). The highest growth took place between 2012-2015, due primarily to the Syrian conflict. More than half of the Syrian population has been displaced internally or across borders. Over 6.3 million Syrians have fled Syria since 2011, many seeking safety in neighboring countries and beyond (UNHCR 2018a). This humanitarian crisis has generated public sympathy as well as concern about the implications of such a massive flow of people.

Neighboring, developing countries host the vast majority (85\%) of the world's refugees, including from the Syrian conflict (UNHCR 2018a). Jordan, which shares a border with Syria, has experienced a substantial influx of Syrians, with 1.3 million Syrians living in Jordan as of the 2015 Population Census (Department of Statistics (Jordan) 2015a). ${ }^{5}$ Compared to a total population of 6.6 million Jordanians in 2015 (Department of Statistics (Jordan) 2015a), the Syrian influx represents a major increase in Jordan's population. The impact of such a massive influx of people on members of the host community, in particular on their labor market outcomes, is a subject of great importance and debate. This paper empirically investigates the impact of the Syrian refugee influx on labor market outcomes in Jordan.

There is a large literature on the impacts of immigration on the labor market, mostly focusing on voluntary and typically economic immigration. ${ }^{6}$ See, for example, Peri (2016) for a

\footnotetext{
${ }^{5}$ As of March 2018, there were 659,000 Syrians in Jordan registered as refugees with the United Nations High Commissioner for Refugees (UNHCR) (UNHCR 2018c). Not all Syrians within Jordan are necessarily registered as refugees. However, since the vast majority of Syrians in Jordan are either registered as refugees or fled Syria due to conflict or violence (Krafft et al. 2018), we refer to Syrians in Jordan synonymously as refugees (broadly defined).

${ }^{6}$ See e.g. Kerr and Kerr (2011) and Dustmann et al. (2016).
} 
review of the evolution of theory and evidence. However, the literature on the impact of refugees on host labor markets is small but growing. For instance, one of the most studied cases is the effect of the 1980 Mariel boatlift from Cuba to Miami. Card's (1990) seminal paper studied the impact of this influx on natives' employment and wages and found no adverse effects. Several subsequent papers, for example Clemens and Hunt (2017) and Peri and Yasenov (2017), have revisited those findings and in some cases, such as Borjas and Monras (2017), come to different conclusions. Overall, the results from this literature suggest no or small negative impacts on natives.

A few papers have examined the impact of refugees on labor markets in host countries from the developing world. Maystadt and Verwimp (2014) found Rwandan and Burundian refugee inflows had a slightly negative impact on the employment outcomes of Tanzanian agricultural workers, while Ruiz and Vargas-Silva (2016) showed that native Tanzanians adjusted to the refugee flows by changing economic activities in the long run. Alix-Garcia et al. (2018) show that natives living near refugee camps benefit from new employment opportunities and favorable price changes. However, these studies examine the long-term effects (decades after the inflow) as opposed to our focus here, which is on shorter-term effects. There may be a period of substantial adjustment in the labor market in the wake of a refugee influx.

For the case of Syrian refugees, there is a very recent literature looking at the impact of Syrian refugees in Turkey. Tumen (2016) examined the impact of Syrian refugee inflows in Turkey and found small but statistically significant informal employment losses among natives in Turkey. He focused on the first two years of the refugee inflows, an era in which both the decision to migrate and the location choice within Turkey can be assumed to be exogenous. Bagir (2017) analyzed the initial (primary) migration to Turkey’s borders, and (secondary) migration from the borders to the inner region of Turkey separately. He found statistically significant negative 
employment and wage effects on low-skilled and less experienced Turkish natives in the primary migration. The secondary migration did not show a statistically significant negative employment effect, however, it did generate significantly lower wages, particularly for low-skilled and less experienced informal Turkish workers. Ceritoglu et al. (2017) also found negative impacts of Syrian refugee inflows on Turkish natives’ labor market outcomes: increasing unemployment and reducing labor force participation, informal employment and job finding rates among natives. Similarly, Del Carpio and Wagner (2015) found large-scale displacement of natives by refugees in the informal sector in Turkey.

In contrast, Cengiz and Tekguc (2017) argue that immigrants might bring capital and purchasing power to local economies and shift labor demand to offset any negative labor supply effects. Estimating a difference-in-difference model for Turkey, Cengiz and Tekguc (2017) as well as Akgündüz, van den Berg, and Hassink (2015) found no sizable negative impact of Syrian migrants on the native workforce. While their methods were similar to Ceritoglu et al. (2017), their results did not show that informal employment declined after 2012. In addition to looking at employment effects, Cengiz and Tekguc (2017) look at wage effects. They find that there is a sharp decline in wages in the early years of the refugee influx for low-skilled, predominantly informal workers, yet it appears their wages quickly recovered. Finally, looking at residential construction and the establishment of new companies, findings confirm that migrants cause a positive demand shock that partially or totally offsets the labor supply shock.

There is little evidence on refugee impacts in Jordan. All the evidence to date is effectively descriptive, looking at patterns of employment over time (Cookle 2017; Fakih and Ibrahim 2015; Stave and Hillesund 2015). The Jordanian case is particularly interesting for several reasons. Until 2016, Syrians were not (officially) allowed to work (Razzaz 2017). Hence, similar to Turkey, if 
they did work, they did so in the informal sector. The Jordan Compact between the European Union (EU) and Jordan in 2016 included humanitarian aid and macro financial assistance as well as trade concessions by the EU. One of the concessions of the Jordanian government in return for this assistance was allowing Syrian refugees in Jordan formal access to the labor market (European Commission 2016). Hence, since 2016, Syrian refugees were allowed work permits in certain sectors, such as agriculture, construction, food, and manufacturing (Razzaz 2017). These sectors disproportionately employed migrant labor (and relatively few Jordanians) even prior to the conflict. Although there is a cap of 200,000 on the number of permits offered, only 87,141 had been taken up by the end of 2017 (Ministry of Labour Syrian Refugee Unit 2018).

The main contribution of this paper is providing empirical evidence on the short-term effects of large inflows of refugees on the natives' labor market outcomes in a developing country context. The paper additionally sheds light on the effects of allowing —at least in a limited wayrefugees to work legally, and how complementing legal work opportunities for refugees with aid and trade opportunities may yield offsetting effects for natives’ labor market outcomes.

Economic theory would suggest that a large influx of refugees would yield a labor supply shock in Jordan. First, refugees would displace natives (particularly initially in the informal sector), and this should lower employment and wages in the informal sector. Second, this might lead to complex effects on formal employment and wages depending on the complementarity between the two sectors and access of refugees, once they have work permits. A caveat to this theoretical prediction is that the deal with the European Union that led to Jordan offering work permits also included additional aid and trade concessions (European Commission 2016). These aspects of the deal could generate additional labor demand among Jordanians, as could the general effort to provide aid to refugees, as additional Jordanians work to provide services for refugees. The net 
effect of these labor supply and demand effects is, theoretically, ambiguous. Any potential impact of the Syrian influx will depend not only on the mechanisms of aid, additional labor demand in services, and work permits, but also on the composition of the Syrian refugees in Jordan, and the other laborers (especially migrants) with whom they might compete.

Therefore, in this paper we empirically examine the impact of Syrian refugee inflows on Jordanians' labor market outcomes. We make use of nationally-representative panel data to capture labor market outcomes before (2010) and after (2016) the Syrian influx. We study both the intensive and extensive margins of work as well as employment characteristics. Specifically, we examine employment, unemployment, hours of work, and wages, as well as sector, formality, economic activity, and occupation of employment. In additional models, we split our results along dimensions that may shape labor substitutability, such as sex, age, and education level. We rely on the variation in the share of Syrians by locality to identify the impact of exposure to refugees. We additionally, in some models, control for geographical fixed effects or individual fixed effects. We find there have not been negative effects on employment outcomes, but there have been slight shifts in the type of work Jordanians undertake. This finding has important implications for other countries hosting refugees and considering whether to allow refugees to (legally) participate in the labor market.

The remainder of the paper is organized as follows. Section 2 describes the data used in the analysis. Section 3 introduces the empirical methodology. Section 4 presents the main results followed by the sensitivity analysis in section 5 . Section 6 discusses our results and concludes. 


\section{Data}

\subsection{Jordan Labor Market Panel Survey}

The Jordan Labor Market Panel Survey (JLMPS) provides a unique opportunity to assess the impact of the refugee influx on Jordan's labor market. The initial wave of the JLMPS was fielded in 2010 (primarily January-March), prior to the regional upheaval and Syrian conflict. ${ }^{7}$ The data were nationally representative (after weighting to account for sample stratification along geographic lines). A second wave of the JLMPS was fielded starting in December 2016 (the bulk of data collection finished by April 2017). Both waves of the JLMPS were a collaboration between the Economic Research Forum (ERF) and the Jordanian Department of Statistics (DOS), which was responsible for sampling and fieldwork.

The JLMPS 2016 tracked households from 2010, including individuals who split to form new households. The 2016 wave also added a refresher sample that over-sampled neighborhoods which were identified in the November 2015 population census as having a high proportion of non-Jordanian households. Approximately 3,000 households were added with the refresher sample, which stratified on governorate and urban/rural/(official) camps ${ }^{8}$ as well as high vs. low proportion of households that were non-Jordanian. The 2016 sample weights, based on the 2015 census population, take into account the initial wave sampling strategy, the refresher sampling strategy, and account for attrition between the 2010 and 2016 waves on both the household and split household levels. ${ }^{9}$

\footnotetext{
${ }^{7}$ See Assaad (2014) for more information on the JLMPS 2010. Data are publicly available from ERF Open Access Micro Data Initiative (OAMDI 2018a; b) at: http://www.erfdataportal.com/. 8 The official camps were Za'atari and Azraq.

${ }^{9}$ See Krafft \& Assaad (2018) for details on the data including sample design, attrition modeling, sample weights, and validation of the sample against other data sources. The appropriate weights are used throughout our descriptive and multivariate results.
} 
The panel structure of the JLMPS provides an enormous advantage in being able to observe the impact of the refugee influx that occurred between waves. The JLMPS 2016 also includes a substantial amount of retrospective data, including a re-designed labor market history that improves on previous LMPSs in methods for collecting spells of non-participation and especially unemployment. ${ }^{10}$ Assaad, Krafft, and Yassin (2018), using the Egypt Labor Market Panel Survey and exploiting multiple waves of panel and retrospective data, assessed consistency and measurement error and proposed improvements (which were implemented in JLMPS 2016). The labor market history data collect statuses starting from school exit or first job, whichever is first. They capture, in sequence:

(1) The date of school exit

(2) Any non-employment between school exit and first job (distinguishing between unemployment and out of the labor force).

(3) First job start date and characteristics.

(4) Respondents are then asked if they have left that job, and if so, when and whether they had a period of non-employment (again distinguishing unemployment and out of labor force).

(5) They are then asked if they had a subsequent job, and if so, the start dates and characteristics.

Steps (4) and (5) repeat until all statuses are captured. The sequencing of statuses from initial forwards (rather than current, previous, and pre-previous) as well as the specific addition of detection questions for non-employment (rather than just considering that as a status) were

\footnotetext{
10 The labor market history is asked of those who ever worked; we gather retrospective data on unemployment for those who never worked from the unemployment module, which includes the start date of unemployment.
} 
innovations to improve data quality in response to challenges identified by Assaad, Krafft, and Yassin (2018). We primarily exploit the 2010 to 2016 panel and 2016 retrospective data ${ }^{11}$ to examine a variety of labor market outcomes. We present the results from the repeated crosssections as a sensitivity analysis in Appendix D.

\subsection{Analysis sample}

Our analyses distinguish between two groups. First and foremost, in this paper we are interested in how Jordanians' labor market outcomes were affected by the influx of Syrian refugees. We therefore focus most of our analyses on Jordanians ${ }^{12}$ aged $15-64 .{ }^{13}$ In order to understand the potential impact of Syrian refugees on Jordan's labor market, we, secondarily, descriptively examine the labor market outcomes of Syrian refugees aged 15-64.

Labor markets in Jordan are highly segmented by sex and Jordanians' female labor force participation is near the lowest in the world (17\%) (Assaad, Krafft, and Keo 2018). Very few Syrian women in Jordan participate in the labor force (4\%). Since the women who do participate in Jordan tend to be the most educated and are unlikely to be competing with Syrians, we therefore split all our results by sex and present only the results for men in the body of the paper. The results for women are presented in an Appendix C. In additional sensitivity analyses, we also split the

\footnotetext{
${ }^{11}$ We restrict our analyses of the retrospective data to the period 2004-2017, centered around the year 2010, which is the reference year for all our analyses.

12 The 2010 respondents were almost all Jordanian (92.5\% of individuals, weighted. Individuals of Palestinian origin who have Jordanian nationality are included in this group). There were a substantial share of “Other Arab” respondents (5.0\%), i.e. Palestinians, a small group of Egyptian respondents (2.0\%) and few “Other” respondents (0.1\%). Just $0.5 \%$ of respondents were Syrian in 2010. In 2016, the share of respondents who were Jordanian was $69.4 \%$, followed by $13.3 \%$ Syrian, $8.6 \%$ Other Arab, 6.7\% Egyptian, and 2.1\% Other.

${ }^{13}$ In analyses that use retrospective data, we restrict individuals to be 15-64 in the retrospective year in question. In the retrospective data we also exclude years spent outside of Jordan itself.
} 
sample based on education level (basic or less vs. secondary and higher), since the less-educated may be disproportionately affected. We further split the sample by sector, public versus private, as there may be offsetting or sector-specific effects. These analyses are presented in Appendices $\mathrm{E}$ and $\mathrm{F}$. In appendices $\mathrm{H}$ and I we examine specifically labor market entrants, who may be disproportionately affected by recent developments.

\subsection{Labor market outcome variables}

We examine a number of labor market outcomes. First, we focus on labor market status, classifying individuals as employed, unemployed, or out of the labor force (not shown). In identifying the border between unemployment and non-participation, we require individuals to have been actively searching for work during unemployment (within the past four weeks in the contemporaneous data sources, within the period of non-employment for retrospective data). Work is defined in terms of market work in the past three months; those who do subsistence work only are considered not working.

We then examine a number of outcomes among the employed, ${ }^{14}$ including whether individuals have formal work (with a contract or social insurance) or informal work (neither a contract nor social insurance). We also look at whether workers are in an "open sector," that is, a sector open to Syrians with work permits (agriculture, manufacturing, construction, food service, or domestic/cleaning work (Kelberer 2017)). While Jordanians may be facing competition in the open sector, they may also be receiving more opportunities in other sectors, particularly the public sector. For instance, additional provision of services and international funds may increase public

\footnotetext{
${ }^{14}$ We undertook sensitivity analysis as to whether analyzing these outcomes unconditional on employment, rather than among the employed, changed our results; it did not lead to substantive changes (results available from authors on request).
} 
sector employment, which is open exclusively to Jordanians, while displacement may occur in the private sector. We therefore examine the probability of employment in the private sector among the employed (the complement necessarily being public sector work). ${ }^{15}$ To specifically examine whether aid is likely to be creating jobs in human services, we examine the probability of being employed in the education or health care field among the employed. Further, we examine occupations, specifically an outcome of being in a managerial or professional occupation among the employed, in case there is occupational upgrading occurring. For all workers, we examine hours per week, and for wage workers, we examine both hourly wages and monthly wages.

\subsection{Identifying variation in the Syrian refugee influx}

To assess the impact of the refugee influx, we identify off of variation in where Syrian refugees settled. Syrians could enter Jordan from Syria up through mid-2013 through two official border crossings along Jordan's northern border as well as nearby informal crossings (Francis 2015). In mid-2013 official crossings were closed due security concerns. Informal crossings were subsequently closed as well. Most refugees (87\%) are living in host communities (not camps), although those in host communities may have initially passed through camps (Krafft et al. 2018). The two main camps in Syria are located near the border; Za’atari was established in mid-2012 10 kilometers from the border, near the town of Mafraq, on desert land owned by the Jordanian air force (Ledwith 2014; Reuters 2012). Azraq was subsequently opened in mid-2014 further inland, on a site that housed displaced Iraqis and Kuwaitis during the Gulf War (Oddone 2014). Importantly for identification purposes, neither site was chosen for access to labor market

\footnotetext{
${ }^{15}$ We include work in the small international and NGO sectors with public sector work to capture the effect of aid on these two sectors together, as compared to the private sector.
} 
opportunities. Syrians in host communities also are not equally distributed throughout the country. Refugees are predominantly concentrated in the North of Jordan (in governorates along the border with Syria) and in the capital, Amman.

The refugee influx has thus differentially affected geographic areas within Jordan. We use data from the 2015 census on the number of Syrian households in a particular locality as a measure of the refugee influx. Specifically, we use the percentage of households that are Syrian. We rely on the locality of residence in 2010 throughout our analyses, ${ }^{16}$ using the retrospective residential mobility data to identify 2010 residence even for observations from the 2016 wave. We use 2010 residence throughout in order to avoid estimation problems that might result from Jordanians potentially relocating due to labor market or housing market pressures from the Syrian refugee influx. ${ }^{17}$

Localities are the fourth level of geographic disaggregation (Jordan is divided into governorates, which contain districts, which contain sub-districts, which contain localities). There are 958 localities in Jordan, although we typically cover only around half the localities within Jordan in the JLMPS depending on the data and outcome used. Taking individuals as the unit of analysis, the median individual lives in a locality of 148,398 persons (that is, 50\% of individuals live in localities with more than 148,398 persons and 50\% of individuals live in localities with fewer people). Again analyzing individuals, the $25^{\text {th }}$ percentile individual lives in a locality of size 19,608 and the $75^{\text {th }}$ percentile individual lives a locality of size 258,829 . Although it is highly debatable what a "local" labor market is, localities are a plausible size for a local labor market that would be, potentially, affected by a refugee influx. We investigate the question of what is a local

\footnotetext{
${ }^{16}$ Individuals who were not in Jordan in 2010 are thus dropped.

${ }^{17}$ Few Jordanians changed localities between 2010 and 2016; of the 18,669 individuals covered by the retrospective 2016 data, only 475 report a different locality in 2016 than 2010 .
} 
labor market further in examining, for those working outside the home, the percentage working in their locality of residence, which is $40 \%$. Thus, while many workers may cross locality borders, locality level shocks will definitely affect a substantial share of workers.

Although we have locality level data in the 2016 wave, and thus can use the 2010 locality data based on the 2016 residential mobility for our panel and retrospective analyses, there is not locality level data when using the repeated cross sections (Appendix D), that is when including the 2010 wave. Therefore, we use sub-district level data on the percentage of households that are Syrian, the next geographic level up, with the repeated cross-section. There are 89 sub-districts in Jordan, 88 of which are in the JLMPS. On the sub-district level, 51\% of workers who work outside their home are working in their sub-district of residence. We also undertake sensitivity analyses around different levels of geographic aggregation in Appendix K.

We use the number of Syrian households, rather than individuals, to account for the density of working age men who might enter the labor market. ${ }^{18}$ The refugee population is very young; 48\% of the Syrian refugees in Jordan are young children (aged 0-14) (Krafft et al. 2018). The young age of the refugee population is important to keep in mind in light of potential labor market effects of the influx; young refugees are much more likely to be requiring services, such as education, and receiving aid, than competing in the labor market. Refugee households are predominantly nuclear, as 95\% of household members are either the head, spouse, or offspring of the head (Krafft et al. 2018). Thus, households are an ideal proxy for working age men, more so than number of individuals. Unfortunately, we cannot examine directly the share of working-age

\footnotetext{
${ }^{18}$ We tested the sensitivity of our main results to using the percentage of individuals Syrian instead of households and the results were not substantively different.
} 
individuals in the census because the census data are only available to us already geographically aggregated, not as individual microdata.

\subsection{Control variables}

Our models control for a number of important demographic differences among Jordanians. We consider demographic differences because they may affect labor market outcomes over time, be correlated with the refugee influx, or because certain demographic groups may be particularly affected by the refugee influx. Our models account for respondents' age and age squared. Seven levels of education are controlled for: (1) illiterate (reference) (2) read \& write (3) basic (ten years) (4) secondary (two additional years) (5) post-secondary (two additional years beyond secondary) (6) university (four additional years beyond secondary) and (7) post-graduate. These same education categories are included for mother's and father’s education, although we aggregate postgraduate studies with university for parents. Since many labor market outcomes are predicated on socio-economic status, parents' background is a critical control. This information is available even when the respondent's parents are not in the household. As another proxy for socio-economic background, we control for father's employment status when the respondent was aged 15 as: (1) waged employee (2) employer (3) self-employed (4) unpaid worker (5) non-employed or (6) don’t know. In some specifications we also control for geographic or individual fixed effects (in which case some invariant controls drop out of the models).

\section{Methods}

Our main models of the impact of the refugee influx on Jordanians’ labor market outcomes are linear difference-in-difference models. Denote outcomes as $Y_{i t}$, where $i$ identifies an individual and $t$ denotes time. Further, denote with $l$ a particular locality, so that $S_{l}$ is the control for the share 
(percentage points) of households that were Syrian in the locality from the census in 2015. We estimate:

$$
Y_{i t l}=\beta_{0}+\alpha_{j} X_{i t j}+\gamma S_{l}+\delta_{t} t+\theta_{t} t * S_{l}+\varepsilon_{i t l}
$$

$\gamma$ can be used to measure selection or endogenous placement of Syrians, whether they migrated to where employment conditions were better prior to the influx. $\delta_{t}$ can be used to assess overall time trends (specifically, trends for localities with no Syrians). $t$ is operationalized sometimes as a single control for 2016 (in the panel and repeated cross section models) and sometimes as a vector of years (in the retrospective models). The year 2010 is always the reference year regardless of the specification. The covariate that measures the impact of the influx is the $\theta_{t}$ term on the interaction of share Syrian and time. In the retrospective models, $\theta_{t}$ can also be used to assess the parallel trends assumption by comparing whether $\theta_{t}$ was different over time prior to the influx. We test the parallel trends assumption with a joint test of the pre-2010 (2004-2009) $\theta_{t}$ interaction coefficients. In the panel models and some of the retrospective models we also add individual fixed effects, $\eta_{i}$, to the specification above. Most of the specifications also include a number, $j$, of control variables, $X_{i t j}$, as discussed above.

\section{Results}

Results are presented first, in brief, in terms of descriptive statistics on the population and labor force outcomes of Jordanians and Syrian refugees. We then present the multivariate models using the retrospective data (where we can test parallel trends), and panel data. These are followed, in the next section, by the various robustness checks. 


\subsection{Descriptive Statistics on the Population of Jordanians and Syrians in Jordan}

There has been a substantial influx of nearly 1.3 million Syrians into Jordan between 2010 and 2016. Although the Syrian population as a whole could create labor demand, the main labor supply impact will be from the working-age population. We estimate that from 2010 to 2016, the number of working-age Syrians rose from 19,000 to 644,000 . The Syrian working age population was about $16 \%$ the size of the Jordanian population in 2016, a substantial demographic shift. However, not all working-age adults engage in the labor market. While there were 1.6 million Jordanians in the labor force as of 2016 there were only 143,000 Syrians in the labor force in 2016. The Syrian labor force in 2016 is equivalent to about 9\% of the Jordanian labor force.

The Syrian refugee influx differentially affected different areas within Jordan. Figure 1 presents the sub-district level variation in the refugee influx. Specifically, it shows the percentage of households that are Syrian as well as the number of households (based on the 2015 Census). Our key covariate is the percentage of households that are Syrian, a relative measure, which could vary either due to differences in the number of Syrian households or differences in total population in an area. Both the number of Syrians and the percentage of households that are Syrian vary across sub-districts, ranging from a minimum of $0.5 \%$ or 6 households to a maximum of $82 \%$ or 29,905 households. The labor supply shocks were stronger near the Syrian border and Amman, but did vary substantially across sub-districts even in areas of overall concentration (and even more so across localities). For example, in Amman governorate the sub-district level share of households Syrian varied from a low of $0.6 \%$ to a high of $18 \%$. 
Figure 1. Number and percentage of households that are Syrian, by sub-district
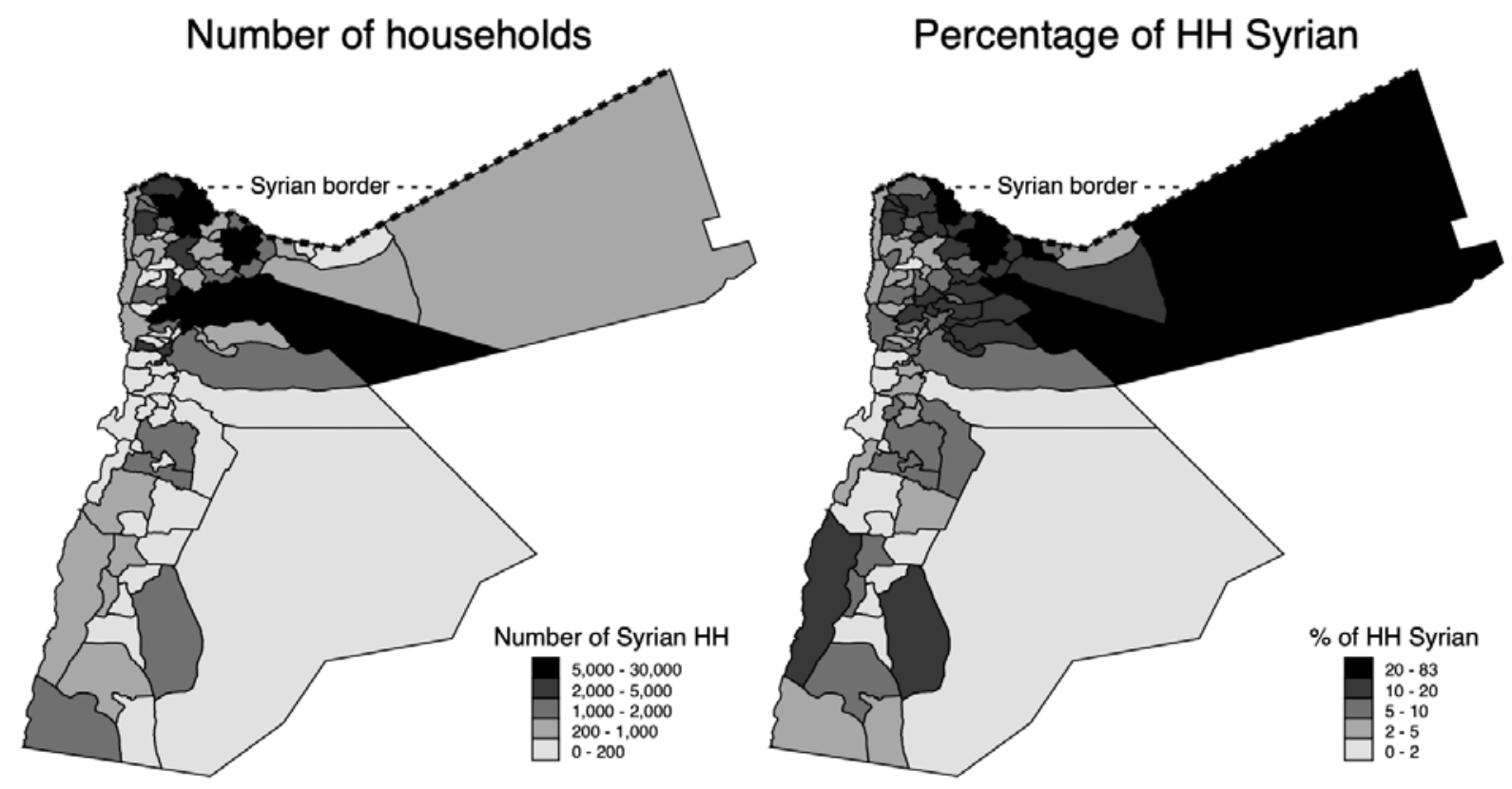

Source: Authors’ calculation based on Census 2015

Focusing on the locality working-age Jordanians lived in as of 2010 (our main covariate and sample), a sizeable proportion of individuals experienced relatively low levels of local labor supply shocks; the $10^{\text {th }}$ percentile is $2.5 \%$ Syrian and the $25^{\text {th }}$ percentile $5.6 \%$. The mean was $10.1 \%$ Syrian and the median $9.6 \%$. On the high end, the $75^{\text {th }}$ percentile was $12.5 \%$ Syrian and the $90^{\text {th }}$ percentile $21.6 \%$. This variation in the local labor market shock is our key source of identification. 
The year of arrival of refugees determines the timing of potential impacts on the labor market. The JLMPS shows that very few Syrians (aged 15-5919) in Jordan in 2016 arrived in 2011 or earlier (8\%). The influx began in 2012 (27\%), peaked in 2013 (48\%) and decreased thereafter (8\% in 2014, 7\% in 2015, and 3\% in 2016/17). ${ }^{20}$ Thus, labor market impacts are likely to have started in 2012 or 2013, although effects may have been delayed by the time it took for demand for goods and services to generate additional labor demand, or for work permits and displacement to occur.

The JLMPS data allow us to directly assess when the Syrians who did work in Jordan started working. Work permits and aid and trade concessions were part of the Jordan Compact, signed February 4, 2016 (International Rescue Committee 2017). Regulations for obtaining work permits were relaxed starting in March of 2016 and work permit fees were waived starting in April of 2016 (Dunmore 2016). Thus, by the time the JLMPS was fielding in December 2016-April 2017, the work permit system had been operational for almost a year. Although work permits started in 2016, Syrians reported starting work before then, presumably informally. Around a fifth of Syrians in Jordan who had ever worked since arriving in Jordan started working in each of 2012 (23\%), 2013 (22\%), and 2014 (21\%). There was a slight decrease of starts, to 12\%, in 2015, after arrivals had tapered off, but an uptick to 17\% in 2016/17, when work permits became available. Although work permits allowed Syrians to work legally in Jordan, the majority were still working without a permit. We estimate 47,000 Syrians aged $15-59^{21}$ worked with work permits. ${ }^{22}$ In contrast,

\footnotetext{
${ }^{19}$ Analyses of certain Syrian refugee outcomes are restricted to ages 15-59 as that was the universe for the in-migration section of the questionnaire.

${ }^{20}$ The arrival timing observed in the JLMPS is consistent with UNHCR registration data as well (UNHCR 2018c).

${ }^{21}$ The age group for which we have data in the JLMPS.

${ }^{22}$ This statistic is consistent with official reports of 37,000 permits issued from January 1, 2016 to January 1, 2017, the latter date in the midst of when JLMPS 2016 was in the field.
} 
approximately 62,000 reported working without a permit. Thus, although some Syrians are potentially competing for legal employment, most are not working legally, which limits the jobs for which they might compete. Syrians are also in somewhat different types of work than Jordanians. They are not holding the public sector jobs that employ $42 \%$ of working Jordanians. Few working Jordanians (17\%) are in the sort of informal or irregular wage work the working Syrians hold (82\%). Syrians may be competing somewhat more with non-Jordanians (primarily economic immigrants). ${ }^{23}$

\subsection{Time trends in Jordanians' labor market outcomes}

As an initial, descriptive assessment of how host community labor markets have shifted since the refugee influx, Figure 2 presents Jordanians' employment rates by sex for 2004-2017 and Figure 3 does likewise for the unemployment rate. Data are presented from the JLMPS 2016 retrospective labor market history as well as contemporaneous annual measures from the Jordanian Employment and Unemployment Survey (EUS). These figures serve two purposes: first, they demonstrate descriptively how the Jordanian labor market has been faring and second, they allow us to assess the consistency of JLMPS retrospective data with contemporaneous EUS data. ${ }^{24}$ EUS employment rates tend to be slightly higher than JLMPS retrospective rates, ${ }^{25}$ although they converge towards the survey year. Unemployment rates are higher in the JLMPS, particularly for women, although these also converge somewhat. The two data sources show relatively similar

\footnotetext{
${ }^{23}$ For an investigation of Syrians' impact on the labor market outcomes of other immigrants in Jordan, see Malaeb \& Wahba (2018).

${ }^{24}$ For comparisons of the consistency of JLMPS 2010 and 2016 contemporaneous data with EUS statistics see Assaad \& Krafft (2018) and Krafft \& Assaad (2018). Contemporaneous statistics are generally close.

${ }^{25}$ Measurement error is a concern with retrospective data and has been investigated with other LMPSs (Assaad, Krafft, and Yassin 2018), leading to improvements in the design of the labor market history for JLMPS 2016.
} 
(fairly static) labor market trends. Labor markets are generally rigid in Jordan (Amer 2018; Assaad and Krafft 2016; Yassine 2013). However, there is substantial variation in the panel and retrospective data to identify off of. For example, using the retrospective sample, we see that among those who reported being unemployed in 2010, 49\% reported being employed in 2016. Among those employed in 2010 in the retrospective data, as of 2016, 88\% reported still being employed, $9 \%$ were out of the labor force, and $3 \%$ were unemployed.

Figure 2. Jordanians' employment rates (percentage of the population) by sex, ages 15-64, 2004-2017

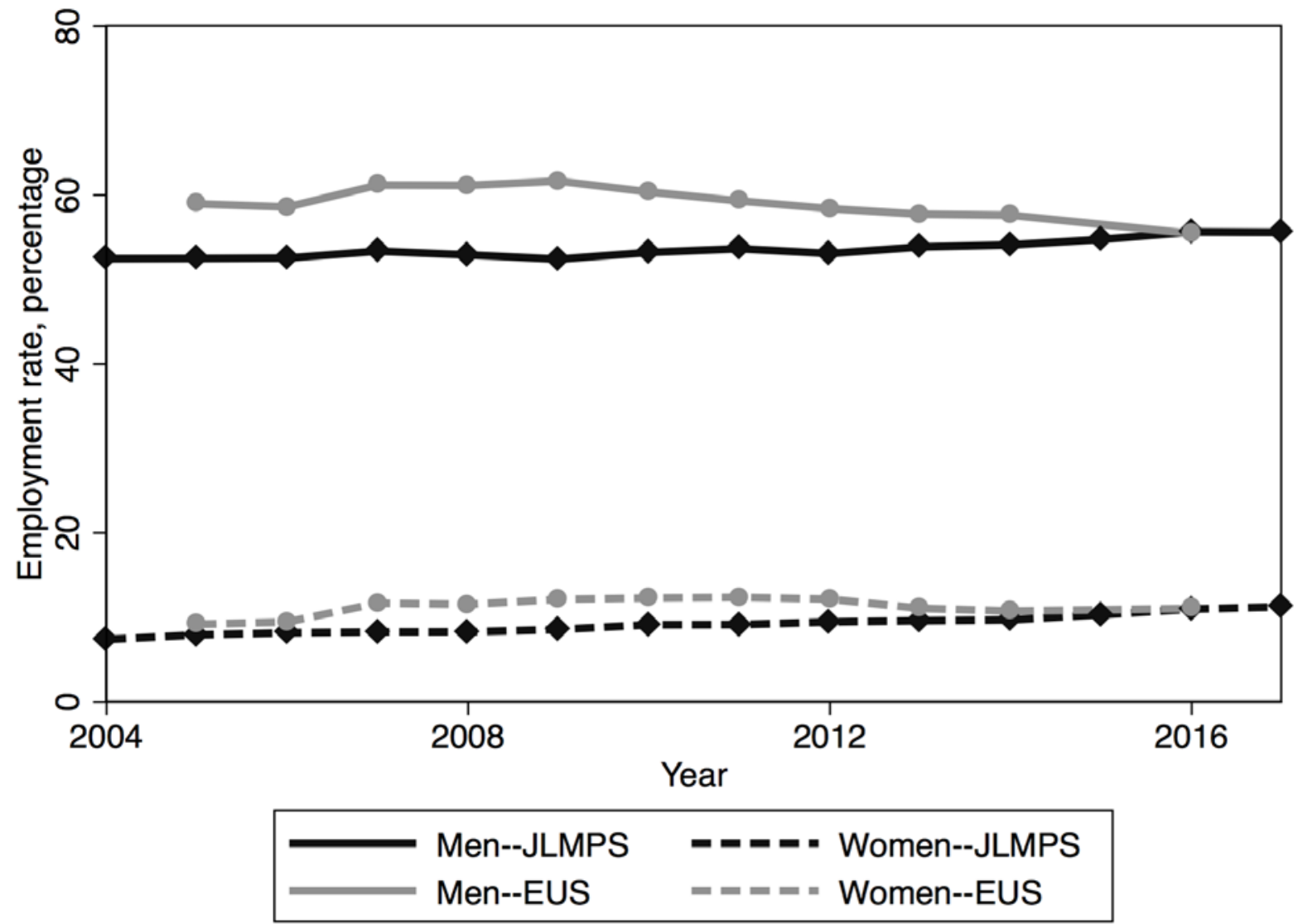

Source: Authors' calculations based on JLMPS 2016 retrospective data and EUS contemporaneous data.

Note: No EUS data in 2004 or 2015 due to Census years 
Figure 3. Jordanians' unemployment rates (percentage of labor force) by sex, ages 15-64, 2004-2017

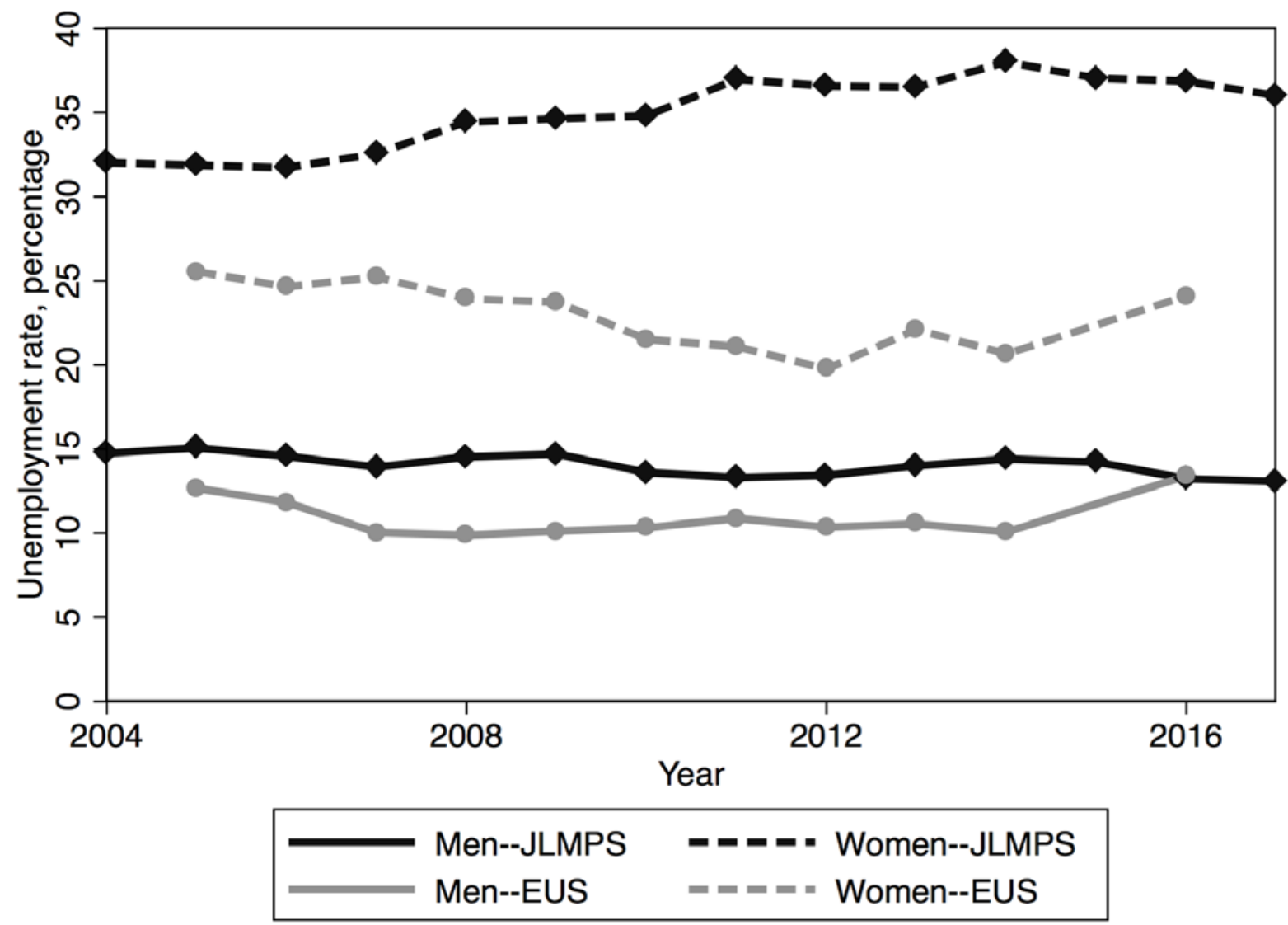

Source: Authors' calculations based on JLMPS 2016 retrospective data and EUS contemporaneous data.

Note: No EUS data in 2004 or 2015 due to Census years

Notably, there is not a substantial or structural shift related to the start of the refugee influx with either data source. Employment had been flat (JLMPS) or declining (EUS) prior to the refugee influx for Jordanian men. Unemployment has likewise fluctuated without any very clear trend. Whether looking at employment or unemployment, regardless of data source, there are not structural changes. Such changes could, however, be localized or masked by shifting demographics and other trends. As a further descriptive exploration of changes, using the JLMPS data from 2010 and 2016 in Appendix A we explore changes over time in our various labor market outcomes for Jordanians. Among employed Jordanians, jobs became slightly more formal, shifted into the public 
sector, were increasingly in health and human services, and decreasingly in competitive activities. These results are suggestive of shifts in services potentially related to the refugee influx, in particular additional labor demand that may be related to aid and services for refugees.

We investigate the potential for localized changes in Figure 4, which uses 2004 and 2015 Jordanian Census data and reports, on the governorate level, the unemployment rate of Jordanians 15+ in 2004 in 2015 (Department of Statistics (Jordan) 2015b, 2004), the percentage change in the unemployment rate, and the 2015 percentage of the population Syrian. The narrative in Jordan and even in descriptive research is that worsening labor market outcomes for Jordanians are (at least partly) a result of the Syrian influx (Francis 2015; International Rescue Committee 2017; Stave and Hillesund 2015). The results of the figure, however, show that, between 2004 and 2015, unemployment decreased the most in the areas that had the most Syrians. This pattern has been corroborated comparing 2010 and 2016 (Assaad, Krafft, and Keo 2018) and noted by other authors as well (Ajluni and Kawar 2014). The contradiction between the popular wisdom in Jordan and even the most basic descriptive results can be explained in part by difficulties in distinguishing the negative effect of the Syrian conflict and deteriorating macroeconomic conditions associated with the conflict from the Syrian refugees. The common narrative suffers from omitted variable bias. In order to properly identify the labor market impacts of refugees, we now turn to our multivariate models. 
Figure 4. Unemployment rates in 2004 and 2015 (percentages), percentage change in unemployment rate from 2004 to 2015, and 2015 percentage of households Syrian, by governorate

2015 Unemp. rate Jordanians 15+

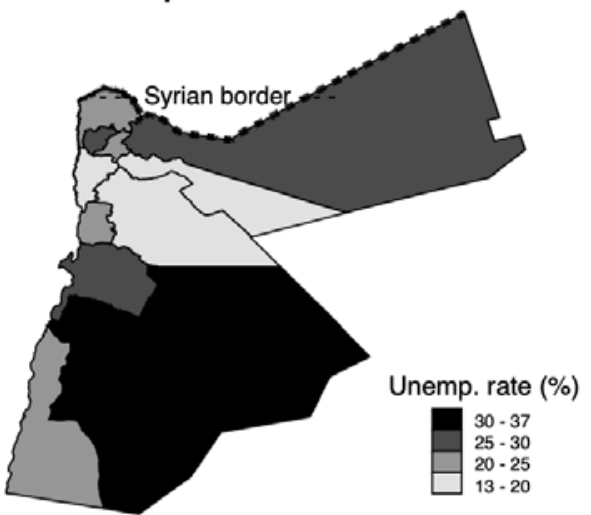

2004 Unemp. rate Jordanians 15+

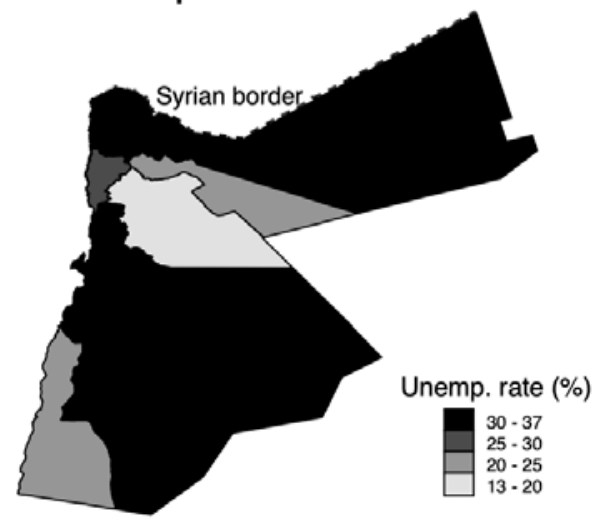

2015 Percentage of HH Syrian

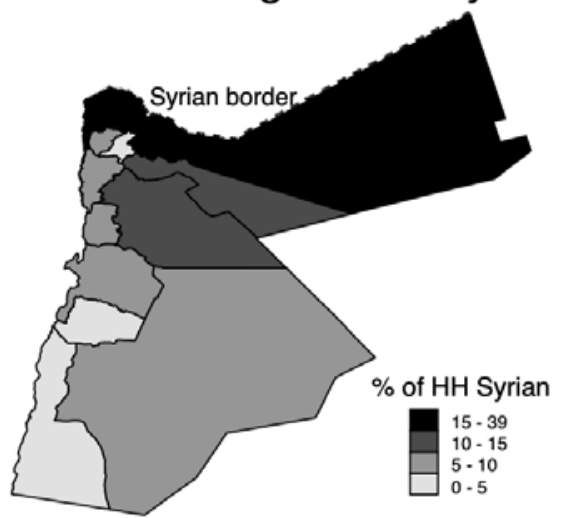

$\%$ change in unemp. rate 2004 to 2015

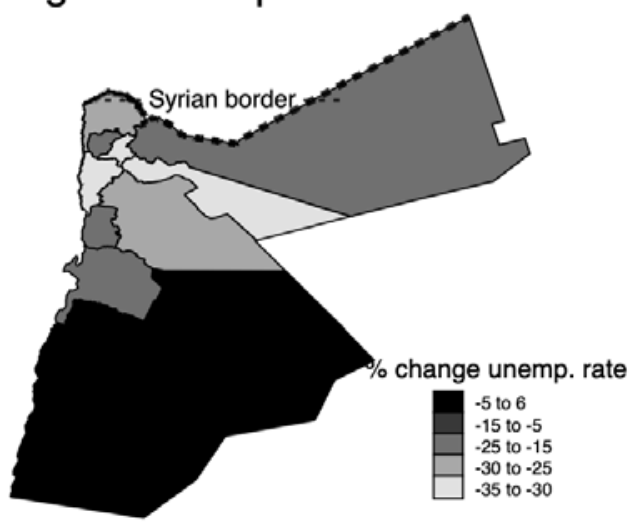

Source: Authors’ calculations based on 2004 and 2015 Census

\subsection{Retrospective models}

In this section we discuss the difference-in difference estimates using the retrospective data. For each outcome, we present the results with various specifications: the first model includes only the difference-in-difference estimates, locality share of refugees, and year dummies. The second specification controls for individual observed characteristics, while the third adds locality fixed effects to the individual controls. The fourth (our preferred specification) uses individual fixed effects. 
Table 1 presents the results on employment and unemployment for men. Since the omitted year is 2010, the coefficient on percentage of households that are Syrian tests for endogenous placement of Syrians relative to 2010, that is, whether Syrians may be in localities where there were differential labor market outcomes preceding the influx. The year coefficients show time trends overall (effectively for a locality with no Syrians), while the interactions between the year and percentage of households Syrian prior to 2010 test for parallel trends and those after 2010 show the impact of Syrians. ${ }^{26}$ Note that the percentage of households Syrian has a (potential) range from $0-100$, so the coefficients for this main effect and interaction show the labor market impact for a one percentage point increase in the share of households that are Syrian in the locality.

\footnotetext{
${ }^{26}$ In Appendix B we test the sensitivity of results to pooling the data instead of estimating single year effects.
} 
Table 1. Labor market status (linear probability model), men, retrospective data, 2004-2017

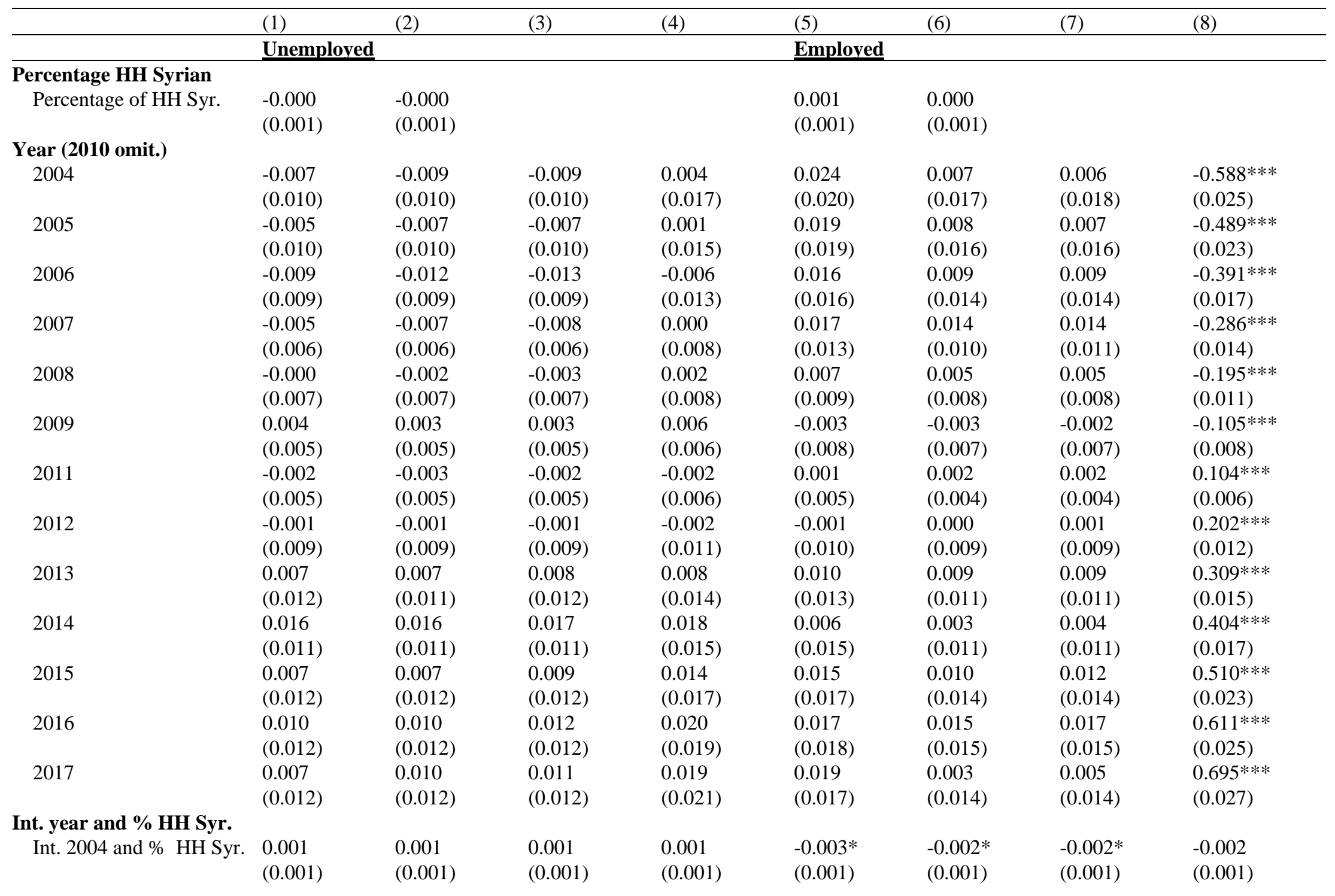




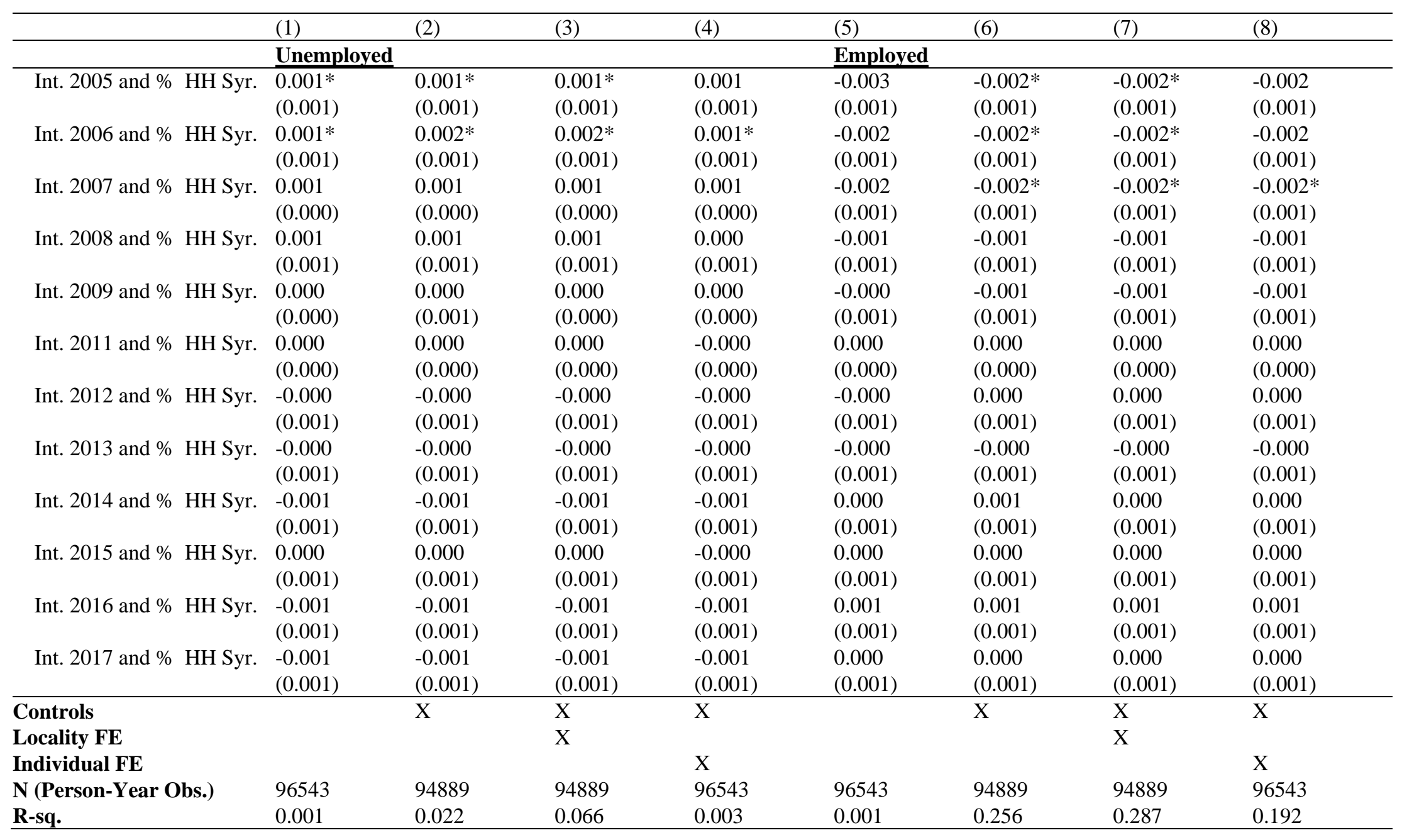

Source: Authors' calculations based on JLMPS 2016

Notes: ${ }^{*} \mathrm{p}<0.05 ;{ }^{* *} \mathrm{p}<0.01 ;{ }^{* * *} \mathrm{p}<0.001$

Controls include education level, mother's education level, father's education level, father's employment status, age, and age squared Standard errors (in parentheses) clustered at the 2010 locality level 
The results for the parsimonious model show that the difference-in-difference estimates capturing the impact of refugees (the coefficient on the interaction) on being out of the labor force are all small, mixed in sign over time, and insignificant for all the years following the influx of the Syrian refugees. This conclusion does not change even when controlling for individual characteristics, locality fixed effects, or individual fixed effects.

The main advantage of using the retrospective data is that it can test the parallel trend assumption for the years preceding the refugee shock. We undertake a joint test of the 2004-2009 interactions as a test of parallel trends. The joint test is insignificant for every outcome except formality. Thus, with one exception, there are parallel trends. For men, formality was higher but falling prior to the influx in areas that received a larger share of Syrians. Assuming this trend were to continue, it would bias our results such that we would expect significantly lower formality postinflux in areas that had a larger influx.

Next, we focus on outcomes among the employed and explore the extent to which the refugee shock has affected employment characteristics. Competition with native workers is expected to be strongest in the informal sector. To test this hypothesis, we first estimate a model for being employed in the formal sector. The results for men are reported in Table 2 and show no significant effect (despite the potential non-parallel trend biasing towards a negative effect should the trend continue). Nor is there a change in being in a managerial or professional occupation. 
Table 2. Job formality and occupation (linear probability model), employed men, retrospective data, 2004-2017

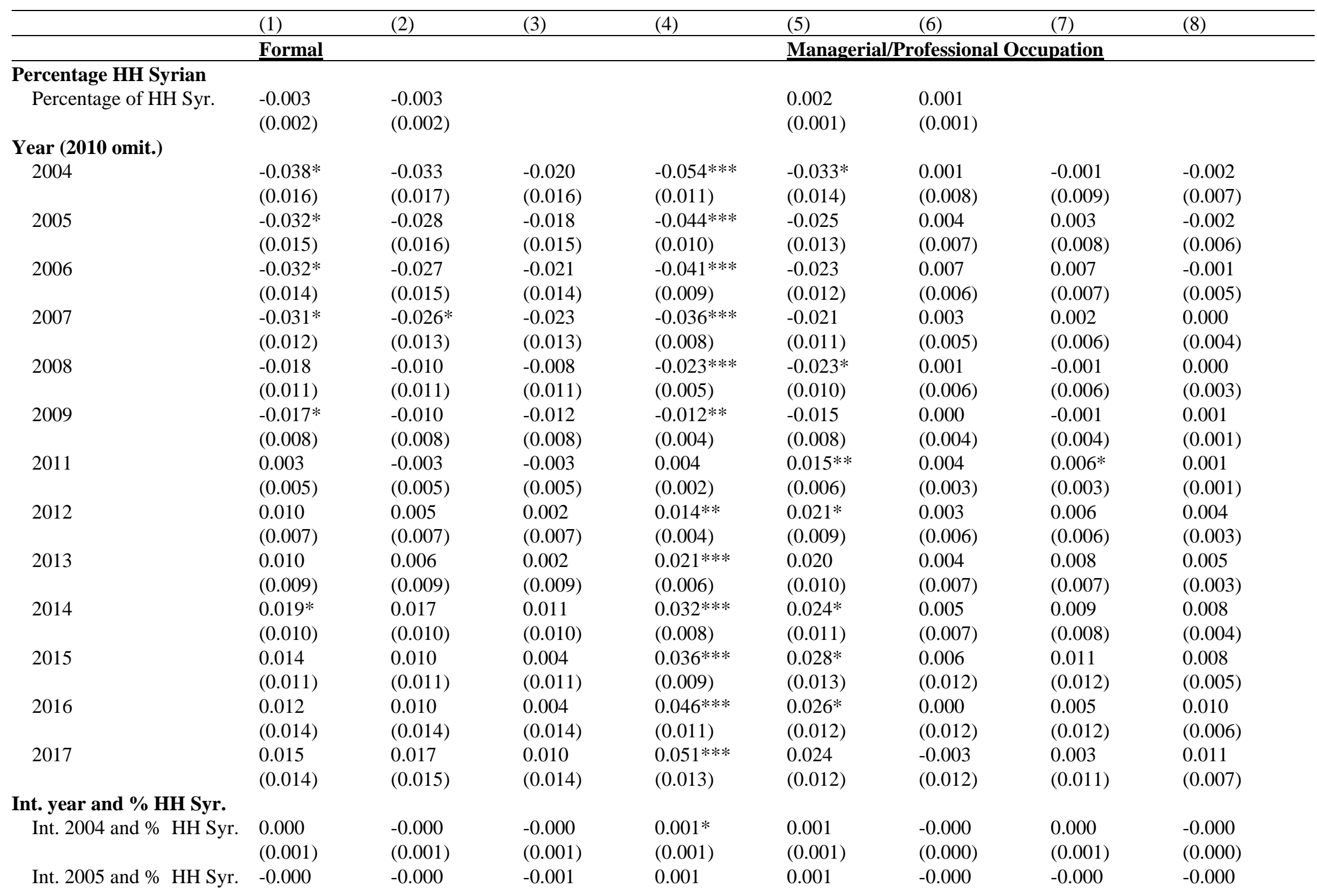




\begin{tabular}{|c|c|c|c|c|c|c|c|c|}
\hline & $(1)$ & $(2)$ & (3) & (4) & $(5)$ & (6) & $(7)$ & $(8)$ \\
\hline & \multicolumn{4}{|l|}{ Formal } & \multicolumn{4}{|c|}{ Managerial/Professional Occupation } \\
\hline \multirow{3}{*}{ Int. 2006 and \% HH Syr. } & $\overline{(0.001)}$ & $(0.001)$ & $(0.001)$ & $(0.001)$ & $(0.001)$ & $(0.000)$ & $(0.001)$ & $(0.000)$ \\
\hline & 0.000 & 0.000 & 0.000 & $0.001^{* *}$ & 0.000 & -0.001 & -0.000 & -0.000 \\
\hline & $(0.001)$ & $(0.001)$ & $(0.001)$ & $(0.001)$ & $(0.001)$ & $(0.000)$ & $(0.000)$ & $(0.000)$ \\
\hline \multirow[t]{2}{*}{ Int. 2007 and \% HH Syr. } & 0.001 & 0.001 & 0.001 & 0.001 & 0.001 & 0.000 & 0.000 & -0.000 \\
\hline & $(0.001)$ & $(0.001)$ & $(0.001)$ & $(0.001)$ & $(0.001)$ & $(0.000)$ & $(0.000)$ & $(0.000)$ \\
\hline \multirow[t]{2}{*}{ Int. 2008 and \% HH Syr. } & 0.001 & 0.000 & 0.000 & $0.001 *$ & 0.001 & 0.000 & 0.000 & -0.000 \\
\hline & $(0.001)$ & $(0.001)$ & $(0.001)$ & $(0.000)$ & $(0.001)$ & $(0.000)$ & $(0.000)$ & $(0.000)$ \\
\hline \multirow[t]{2}{*}{ Int. 2009 and \% HH Syr. } & 0.001 & 0.001 & 0.001 & 0.000 & 0.001 & -0.000 & 0.000 & -0.000 \\
\hline & $(0.001)$ & $(0.001)$ & $(0.001)$ & $(0.000)$ & $(0.001)$ & $(0.000)$ & $(0.000)$ & $(0.000)$ \\
\hline \multirow[t]{2}{*}{ Int. 2011 and \% HH Syr. } & -0.000 & 0.000 & 0.000 & -0.000 & -0.000 & -0.000 & -0.000 & 0.000 \\
\hline & $(0.000)$ & $(0.000)$ & $(0.000)$ & $(0.000)$ & $(0.000)$ & $(0.000)$ & $(0.000)$ & $(0.000)$ \\
\hline \multirow[t]{2}{*}{ Int. 2012 and \% HH Syr. } & -0.000 & 0.000 & 0.000 & -0.000 & -0.001 & -0.000 & -0.000 & -0.000 \\
\hline & $(0.001)$ & $(0.001)$ & $(0.001)$ & $(0.000)$ & $(0.001)$ & $(0.000)$ & $(0.000)$ & $(0.000)$ \\
\hline \multirow[t]{2}{*}{ Int. 2013 and \% HH Syr. } & -0.000 & 0.000 & 0.000 & -0.000 & -0.001 & 0.000 & -0.000 & -0.000 \\
\hline & $(0.001)$ & $(0.001)$ & $(0.001)$ & $(0.000)$ & $(0.001)$ & $(0.000)$ & $(0.000)$ & $(0.000)$ \\
\hline \multirow[t]{2}{*}{ Int. 2014 and \% HH Syr. } & -0.000 & -0.000 & 0.000 & -0.000 & -0.001 & 0.000 & -0.000 & -0.000 \\
\hline & $(0.001)$ & $(0.001)$ & $(0.001)$ & $(0.000)$ & $(0.001)$ & $(0.000)$ & $(0.000)$ & $(0.000)$ \\
\hline \multirow[t]{2}{*}{ Int. 2015 and \% HH Syr. } & -0.000 & 0.000 & 0.000 & -0.000 & -0.001 & -0.000 & -0.001 & -0.000 \\
\hline & $(0.001)$ & $(0.001)$ & $(0.001)$ & $(0.000)$ & $(0.001)$ & $(0.001)$ & $(0.001)$ & $(0.000)$ \\
\hline \multirow[t]{2}{*}{ Int. 2016 and \% HH Syr. } & 0.000 & 0.001 & 0.001 & -0.000 & -0.001 & -0.000 & -0.000 & -0.000 \\
\hline & $(0.001)$ & $(0.001)$ & $(0.001)$ & $(0.000)$ & $(0.001)$ & $(0.001)$ & $(0.001)$ & $(0.000)$ \\
\hline \multirow[t]{2}{*}{ Int. 2017 and \% HH Syr. } & -0.000 & 0.000 & 0.001 & -0.000 & -0.001 & -0.000 & -0.000 & -0.000 \\
\hline & $(0.001)$ & $(0.001)$ & $(0.001)$ & $(0.000)$ & $(0.001)$ & $(0.001)$ & $(0.001)$ & $(0.000)$ \\
\hline Controls & & $\mathrm{X}$ & $\mathrm{X}$ & $\mathrm{X}$ & & $\mathrm{X}$ & $\mathrm{X}$ & $\mathrm{X}$ \\
\hline Locality FE & & & $\mathrm{X}$ & & & & $X$ & \\
\hline Individual FE & & & & $\mathrm{X}$ & & & & $\mathrm{X}$ \\
\hline N (Person-Year Obs.) & 51123 & 50449 & 50449 & 51123 & 50732 & 50065 & 50065 & 50732 \\
\hline R-sq. & 0.002 & 0.099 & 0.209 & 0.006 & 0.003 & 0.555 & 0.588 & 0.001 \\
\hline
\end{tabular}

Source: Authors’ calculations based on JLMPS 2016

Notes: ${ }^{*} \mathrm{p}<0.05 ;{ }^{* *} \mathrm{p}<0.01 ;{ }^{* * *} \mathrm{p}<0.001$

Controls include education level, mother's education level, father's education level, father's employment status, age, and age squared Standard errors (in parentheses) clustered at the locality level 
We then examine whether the refugee shock affected the type of economic activity or sector (Table 3). Specifically, we estimate the probability of being employed in the open sector, where refugees can get work permits, the health and human services sector, where aid flows and human service needs might be creating jobs, as well as the private sector, where refugees could potentially (legally) compete. The results show no effect on the open sector or health and human services sector in our preferred specification. In our preferred specification there was a significant and, counter-intuitively, positive effect of local refugees on the probability of private sector employment in 2012 and 2013, which disappears in later years. It may be that the influx of refugees initially provided private sector employment opportunities, for example, in retail trades, which then diminished as refugees settled or were offset by subsequent increases in the public sector to deliver services. 
Table 3. Job sector (linear probability model), employed men, retrospective data, 2004-2017

\begin{tabular}{|c|c|c|c|c|c|c|c|c|c|c|c|c|}
\hline & $(1)$ & $(2)$ & $(3)$ & (4) & (5) & $(6)$ & $(7)$ & $(8)$ & (9) & $(10)$ & $(11)$ & $(12)$ \\
\hline & \multicolumn{4}{|c|}{ Open Sector } & \multicolumn{4}{|c|}{ Health and Human Services } & \multicolumn{4}{|c|}{ Private Sector } \\
\hline \multicolumn{13}{|l|}{ Percentage HH Syrian } \\
\hline Percentage of HH Syr. & $\begin{array}{l}-0.001 \\
(0.002)\end{array}$ & $\begin{array}{l}-0.000 \\
(0.002)\end{array}$ & & & $\begin{array}{l}0.002 \\
(0.001)\end{array}$ & $\begin{array}{l}0.001 \\
(0.001)\end{array}$ & & & $\begin{array}{l}0.000 \\
(0.003)\end{array}$ & $\begin{array}{l}0.000 \\
(0.002)\end{array}$ & & \\
\hline \multicolumn{13}{|l|}{ Year (2010 omit.) } \\
\hline 2004 & $\begin{array}{l}0.010 \\
(0.011)\end{array}$ & $\begin{array}{l}0.007 \\
(0.011)\end{array}$ & $\begin{array}{l}0.008 \\
(0.010)\end{array}$ & $\begin{array}{l}0.026 * \\
(0.010)\end{array}$ & $\begin{array}{l}-0.003 \\
(0.009)\end{array}$ & $\begin{array}{l}0.008 \\
(0.009)\end{array}$ & $\begin{array}{l}0.016 \\
(0.010)\end{array}$ & $\begin{array}{l}-0.001 \\
(0.007)\end{array}$ & $\begin{array}{l}-0.017 \\
(0.016)\end{array}$ & $\begin{array}{l}-0.004 \\
(0.015)\end{array}$ & $\begin{array}{l}-0.019 \\
(0.015)\end{array}$ & $\begin{array}{l}0.022 * \\
(0.010)\end{array}$ \\
\hline 2005 & $\begin{array}{l}0.007 \\
(0.011)\end{array}$ & $\begin{array}{l}0.005 \\
(0.011)\end{array}$ & $\begin{array}{l}0.007 \\
(0.009)\end{array}$ & $\begin{array}{l}0.018 \\
(0.010)\end{array}$ & $\begin{array}{l}-0.003 \\
(0.009)\end{array}$ & $\begin{array}{l}0.006 \\
(0.008)\end{array}$ & $\begin{array}{l}0.013 \\
(0.009)\end{array}$ & $\begin{array}{l}-0.002 \\
(0.006)\end{array}$ & $\begin{array}{l}-0.012 \\
(0.015)\end{array}$ & $\begin{array}{l}-0.002 \\
(0.013)\end{array}$ & $\begin{array}{l}-0.014 \\
(0.014)\end{array}$ & $\begin{array}{l}0.020 * \\
(0.009)\end{array}$ \\
\hline 2006 & $\begin{array}{l}0.006 \\
(0.010)\end{array}$ & $\begin{array}{l}0.003 \\
(0.010)\end{array}$ & $\begin{array}{l}0.008 \\
(0.010)\end{array}$ & $\begin{array}{l}0.015 \\
(0.008)\end{array}$ & $\begin{array}{l}-0.005 \\
(0.008)\end{array}$ & $\begin{array}{l}0.003 \\
(0.007)\end{array}$ & $\begin{array}{l}0.009 \\
(0.009)\end{array}$ & $\begin{array}{l}-0.000 \\
(0.006)\end{array}$ & $\begin{array}{l}-0.012 \\
(0.014)\end{array}$ & $\begin{array}{l}-0.003 \\
(0.013)\end{array}$ & $\begin{array}{l}-0.007 \\
(0.011)\end{array}$ & $\begin{array}{l}0.017^{*} \\
(0.008)\end{array}$ \\
\hline 2007 & $\begin{array}{l}0.010 \\
(0.009)\end{array}$ & $\begin{array}{l}0.007 \\
(0.009)\end{array}$ & $\begin{array}{l}0.011 \\
(0.009)\end{array}$ & $\begin{array}{l}0.010 \\
(0.005)\end{array}$ & $\begin{array}{l}-0.011 \\
(0.007)\end{array}$ & $\begin{array}{l}-0.004 \\
(0.006)\end{array}$ & $\begin{array}{l}0.000 \\
(0.007)\end{array}$ & $\begin{array}{l}-0.000 \\
(0.004)\end{array}$ & $\begin{array}{l}-0.008 \\
(0.011)\end{array}$ & $\begin{array}{l}-0.001 \\
(0.011)\end{array}$ & $\begin{array}{l}-0.003 \\
(0.012)\end{array}$ & $\begin{array}{l}0.012 \\
(0.006)\end{array}$ \\
\hline 2008 & $\begin{array}{l}0.006 \\
(0.009)\end{array}$ & $\begin{array}{l}0.001 \\
(0.009)\end{array}$ & $\begin{array}{l}0.006 \\
(0.009)\end{array}$ & $\begin{array}{l}0.009 * \\
(0.004)\end{array}$ & $\begin{array}{l}-0.008 \\
(0.007)\end{array}$ & $\begin{array}{l}-0.001 \\
(0.007)\end{array}$ & $\begin{array}{l}0.001 \\
(0.007)\end{array}$ & $\begin{array}{l}0.001 \\
(0.003)\end{array}$ & $\begin{array}{l}-0.011 \\
(0.010)\end{array}$ & $\begin{array}{l}-0.010 \\
(0.010)\end{array}$ & $\begin{array}{l}-0.009 \\
(0.011)\end{array}$ & $\begin{array}{l}0.006 \\
(0.004)\end{array}$ \\
\hline 2009 & $\begin{array}{l}0.007 \\
(0.007)\end{array}$ & $\begin{array}{l}0.003 \\
(0.007)\end{array}$ & $\begin{array}{l}0.006 \\
(0.006)\end{array}$ & $\begin{array}{l}0.003 \\
(0.003)\end{array}$ & $\begin{array}{l}-0.012 * \\
(0.005)\end{array}$ & $\begin{array}{l}-0.008 \\
(0.004)\end{array}$ & $\begin{array}{l}-0.005 \\
(0.004)\end{array}$ & $\begin{array}{l}-0.000 \\
(0.001)\end{array}$ & $\begin{array}{l}-0.006 \\
(0.008)\end{array}$ & $\begin{array}{l}-0.007 \\
(0.007)\end{array}$ & $\begin{array}{l}-0.003 \\
(0.006)\end{array}$ & $\begin{array}{l}0.001 \\
(0.003)\end{array}$ \\
\hline 2011 & $\begin{array}{l}-0.002 \\
(0.005)\end{array}$ & $\begin{array}{l}0.001 \\
(0.004)\end{array}$ & $\begin{array}{l}-0.002 \\
(0.004)\end{array}$ & $\begin{array}{l}-0.003 \\
(0.003)\end{array}$ & $\begin{array}{l}0.005 \\
(0.003)\end{array}$ & $\begin{array}{l}0.001 \\
(0.003)\end{array}$ & $\begin{array}{l}0.000 \\
(0.003)\end{array}$ & $\begin{array}{l}0.001 \\
(0.001)\end{array}$ & $\begin{array}{l}-0.000 \\
(0.005)\end{array}$ & $\begin{array}{l}-0.001 \\
(0.006)\end{array}$ & $\begin{array}{l}-0.000 \\
(0.004)\end{array}$ & $\begin{array}{l}-0.006^{* *} \\
(0.002)\end{array}$ \\
\hline 2012 & $\begin{array}{l}-0.008 \\
(0.006)\end{array}$ & $\begin{array}{l}-0.004 \\
(0.005)\end{array}$ & $\begin{array}{l}-0.003 \\
(0.005)\end{array}$ & $\begin{array}{l}-0.009^{*} \\
(0.004)\end{array}$ & $\begin{array}{l}0.008 \\
(0.004)\end{array}$ & $\begin{array}{l}0.002 \\
(0.004)\end{array}$ & $\begin{array}{l}-0.001 \\
(0.004)\end{array}$ & $\begin{array}{l}0.003 \\
(0.002)\end{array}$ & $\begin{array}{l}-0.007 \\
(0.009)\end{array}$ & $\begin{array}{l}-0.011 \\
(0.009)\end{array}$ & $\begin{array}{l}-0.001 \\
(0.006)\end{array}$ & $\begin{array}{l}-0.011^{* *} \\
(0.003)\end{array}$ \\
\hline 2013 & $\begin{array}{l}-0.012 \\
(0.008)\end{array}$ & $\begin{array}{l}-0.010 \\
(0.008)\end{array}$ & $\begin{array}{l}-0.006 \\
(0.008)\end{array}$ & $\begin{array}{l}-0.016 * * \\
(0.006)\end{array}$ & $\begin{array}{l}0.008 \\
(0.005)\end{array}$ & $\begin{array}{l}0.003 \\
(0.005)\end{array}$ & $\begin{array}{l}-0.002 \\
(0.005)\end{array}$ & $\begin{array}{l}0.004 \\
(0.003)\end{array}$ & $\begin{array}{l}-0.017 \\
(0.011)\end{array}$ & $\begin{array}{l}-0.025^{*} \\
(0.011)\end{array}$ & $\begin{array}{l}-0.008 \\
(0.008)\end{array}$ & $\begin{array}{l}-0.019 * * * \\
(0.005)\end{array}$ \\
\hline 2014 & $\begin{array}{l}-0.010 \\
(0.009)\end{array}$ & $\begin{array}{l}-0.009 \\
(0.009)\end{array}$ & $\begin{array}{l}-0.007 \\
(0.009)\end{array}$ & $\begin{array}{l}-0.018^{*} \\
(0.007)\end{array}$ & $\begin{array}{l}0.009 \\
(0.007)\end{array}$ & $\begin{array}{l}0.004 \\
(0.007)\end{array}$ & $\begin{array}{l}-0.001 \\
(0.007)\end{array}$ & $\begin{array}{l}0.004 \\
(0.006)\end{array}$ & $\begin{array}{l}-0.010 \\
(0.013)\end{array}$ & $\begin{array}{l}-0.024 \\
(0.012)\end{array}$ & $\begin{array}{l}-0.006 \\
(0.010)\end{array}$ & $\begin{array}{l}-0.018^{* *} \\
(0.006)\end{array}$ \\
\hline 2015 & $\begin{array}{l}-0.011 \\
(0.010)\end{array}$ & $\begin{array}{l}-0.009 \\
(0.010)\end{array}$ & $\begin{array}{l}-0.006 \\
(0.010)\end{array}$ & $\begin{array}{l}-0.021^{*} \\
(0.008)\end{array}$ & $\begin{array}{l}0.006 \\
(0.008)\end{array}$ & $\begin{array}{l}0.000 \\
(0.008)\end{array}$ & $\begin{array}{l}-0.005 \\
(0.009)\end{array}$ & $\begin{array}{l}0.005 \\
(0.007)\end{array}$ & $\begin{array}{l}-0.001 \\
(0.015)\end{array}$ & $\begin{array}{l}-0.017 \\
(0.015)\end{array}$ & $\begin{array}{l}0.005 \\
(0.011)\end{array}$ & $\begin{array}{l}-0.020 * * \\
(0.008)\end{array}$ \\
\hline 2016 & $\begin{array}{l}0.004 \\
(0.013)\end{array}$ & $\begin{array}{l}0.003 \\
(0.014)\end{array}$ & $\begin{array}{l}0.004 \\
(0.013)\end{array}$ & $\begin{array}{l}-0.027^{* *} \\
(0.010)\end{array}$ & $\begin{array}{l}0.003 \\
(0.008)\end{array}$ & $\begin{array}{l}-0.002 \\
(0.008)\end{array}$ & $\begin{array}{l}-0.009 \\
(0.009)\end{array}$ & $\begin{array}{l}0.006 \\
(0.007)\end{array}$ & $\begin{array}{l}0.018 \\
(0.016)\end{array}$ & $\begin{array}{l}-0.006 \\
(0.017)\end{array}$ & $\begin{array}{l}0.015 \\
(0.013)\end{array}$ & $\begin{array}{l}-0.025^{* *} \\
(0.009)\end{array}$ \\
\hline 2017 & $\begin{array}{l}0.004 \\
(0.012)\end{array}$ & $\begin{array}{l}0.001 \\
(0.014)\end{array}$ & $\begin{array}{l}0.002 \\
(0.014)\end{array}$ & $\begin{array}{l}-0.031 * * \\
(0.011)\end{array}$ & $\begin{array}{l}0.003 \\
(0.008)\end{array}$ & $\begin{array}{l}-0.003 \\
(0.009)\end{array}$ & $\begin{array}{l}-0.011 \\
(0.009)\end{array}$ & $\begin{array}{l}0.007 \\
(0.008)\end{array}$ & $\begin{array}{l}0.017 \\
(0.017)\end{array}$ & $\begin{array}{l}-0.015 \\
(0.017)\end{array}$ & $\begin{array}{l}0.011 \\
(0.013)\end{array}$ & $\begin{array}{l}-0.030 * * \\
(0.010)\end{array}$ \\
\hline \multicolumn{13}{|l|}{ Int. year and \% HH Syr. } \\
\hline Int. 2004 and \% HH Syr. & $\begin{array}{l}-0.000 \\
(0.001)\end{array}$ & $\begin{array}{l}0.000 \\
(0.001)\end{array}$ & $\begin{array}{l}-0.000 \\
(0.001)\end{array}$ & $\begin{array}{l}0.000 \\
(0.000)\end{array}$ & $\begin{array}{l}-0.000 \\
(0.001)\end{array}$ & $\begin{array}{l}-0.001 \\
(0.001)\end{array}$ & $\begin{array}{l}-0.001 \\
(0.001)\end{array}$ & $\begin{array}{l}-0.000 \\
(0.000)\end{array}$ & $\begin{array}{l}0.003^{*} \\
(0.001)\end{array}$ & $\begin{array}{l}0.003^{*} \\
(0.001)\end{array}$ & $\begin{array}{l}0.002 * \\
(0.001)\end{array}$ & $\begin{array}{l}0.000 \\
(0.001)\end{array}$ \\
\hline Int. 2005 and \% HH Syr. & 0.000 & 0.000 & -0.000 & 0.001 & -0.000 & -0.001 & -0.001 & -0.000 & $0.002 *$ & $0.002 *$ & $0.002 *$ & 0.000 \\
\hline
\end{tabular}




\begin{tabular}{|c|c|c|c|c|c|c|c|c|c|c|c|c|}
\hline & $(1)$ & $(2)$ & $(3)$ & $(4)$ & (5) & $(6)$ & $(7)$ & $(8)$ & (9) & $(10)$ & $(11)$ & $(12)$ \\
\hline & \multicolumn{4}{|c|}{ Open Sector } & \multicolumn{4}{|c|}{ Health and Human Services } & \multicolumn{4}{|c|}{ Private Sector } \\
\hline & $(0.001)$ & $(0.001)$ & $(0.001)$ & $(0.000)$ & $(0.001)$ & $(0.001)$ & $\overline{(0.001)}$ & $(0.000)$ & $(0.001)$ & $(0.001)$ & $(0.001)$ & $(0.001)$ \\
\hline Int. 2006 and \% HH Syr. & $\begin{array}{l}-0.000 \\
(0.001)\end{array}$ & $\begin{array}{l}-0.000 \\
(0.001)\end{array}$ & $\begin{array}{l}-0.001 \\
(0.001)\end{array}$ & $\begin{array}{l}0.000 \\
(0.000)\end{array}$ & $\begin{array}{l}-0.000 \\
(0.001)\end{array}$ & $\begin{array}{l}-0.001 \\
(0.001)\end{array}$ & $\begin{array}{l}-0.001 \\
(0.001)\end{array}$ & $\begin{array}{l}-0.000 \\
(0.000)\end{array}$ & $\begin{array}{l}0.002 \\
(0.001)\end{array}$ & $\begin{array}{l}0.002 \\
(0.001)\end{array}$ & $\begin{array}{l}0.001 \\
(0.001)\end{array}$ & $\begin{array}{l}0.000 \\
(0.001)\end{array}$ \\
\hline Int. 2007 and \% HH Syr. & $\begin{array}{l}-0.001 \\
(0.001)\end{array}$ & $\begin{array}{l}-0.001 \\
(0.001)\end{array}$ & $\begin{array}{l}-0.001 \\
(0.001)\end{array}$ & $\begin{array}{l}-0.000 \\
(0.000)\end{array}$ & $\begin{array}{l}0.000 \\
(0.001)\end{array}$ & $\begin{array}{l}0.000 \\
(0.000)\end{array}$ & $\begin{array}{l}-0.000 \\
(0.000)\end{array}$ & $\begin{array}{l}-0.000 \\
(0.000)\end{array}$ & $\begin{array}{l}0.001 \\
(0.001)\end{array}$ & $\begin{array}{l}0.001 \\
(0.001)\end{array}$ & $\begin{array}{l}0.000 \\
(0.001)\end{array}$ & $\begin{array}{l}0.000 \\
(0.001)\end{array}$ \\
\hline Int. 2008 and \% HH Syr. & $\begin{array}{l}-0.001 \\
(0.001)\end{array}$ & $\begin{array}{l}-0.001 \\
(0.001)\end{array}$ & $\begin{array}{l}-0.001 \\
(0.001)\end{array}$ & $\begin{array}{l}-0.000 \\
(0.000)\end{array}$ & $\begin{array}{l}0.000 \\
(0.000)\end{array}$ & $\begin{array}{l}-0.000 \\
(0.000)\end{array}$ & $\begin{array}{l}-0.000 \\
(0.000)\end{array}$ & $\begin{array}{l}-0.000 \\
(0.000)\end{array}$ & $\begin{array}{l}0.001 \\
(0.001)\end{array}$ & $\begin{array}{l}0.001 \\
(0.001)\end{array}$ & $\begin{array}{l}0.001 \\
(0.001)\end{array}$ & $\begin{array}{l}0.000 \\
(0.000)\end{array}$ \\
\hline Int. 2009 and \% HH Syr. & $\begin{array}{l}-0.001 \\
(0.001)\end{array}$ & $\begin{array}{l}-0.001 \\
(0.001)\end{array}$ & $\begin{array}{l}-0.001 \\
(0.001)\end{array}$ & $\begin{array}{l}-0.000 \\
(0.000)\end{array}$ & $\begin{array}{l}0.000 \\
(0.000)\end{array}$ & $\begin{array}{l}0.000 \\
(0.000)\end{array}$ & $\begin{array}{l}0.000 \\
(0.000)\end{array}$ & $\begin{array}{l}-0.000 \\
(0.000)\end{array}$ & $\begin{array}{l}0.000 \\
(0.001)\end{array}$ & $\begin{array}{l}0.000 \\
(0.001)\end{array}$ & $\begin{array}{l}0.000 \\
(0.000)\end{array}$ & $\begin{array}{l}-0.000 \\
(0.000)\end{array}$ \\
\hline Int. 2011 and \% HH Syr. & $\begin{array}{l}-0.000 \\
(0.000)\end{array}$ & $\begin{array}{l}-0.000 \\
(0.000)\end{array}$ & $\begin{array}{l}0.000 \\
(0.000)\end{array}$ & $\begin{array}{l}0.000 \\
(0.000)\end{array}$ & $\begin{array}{l}-0.000 \\
(0.000)\end{array}$ & $\begin{array}{l}0.000 \\
(0.000)\end{array}$ & $\begin{array}{l}0.000 \\
(0.000)\end{array}$ & $\begin{array}{l}0.000 \\
(0.000)\end{array}$ & $\begin{array}{l}0.000 \\
(0.000)\end{array}$ & $\begin{array}{l}-0.000 \\
(0.000)\end{array}$ & $\begin{array}{l}0.000 \\
(0.000)\end{array}$ & $\begin{array}{l}0.000 \\
(0.000)\end{array}$ \\
\hline Int. 2012 and \% HH Syr. & $\begin{array}{l}-0.000 \\
(0.000)\end{array}$ & $\begin{array}{l}-0.000 \\
(0.000)\end{array}$ & $\begin{array}{l}-0.000 \\
(0.000)\end{array}$ & $\begin{array}{l}0.000 \\
(0.000)\end{array}$ & $\begin{array}{l}-0.001^{*} \\
(0.000)\end{array}$ & $\begin{array}{l}-0.000 \\
(0.000)\end{array}$ & $\begin{array}{l}-0.000 \\
(0.000)\end{array}$ & $\begin{array}{l}-0.000 \\
(0.000)\end{array}$ & $\begin{array}{l}0.000 \\
(0.001)\end{array}$ & $\begin{array}{l}0.000 \\
(0.001)\end{array}$ & $\begin{array}{l}0.000 \\
(0.001)\end{array}$ & $\begin{array}{l}0.000 * \\
(0.000)\end{array}$ \\
\hline Int. 2013 and \% HH Syr. & $\begin{array}{l}0.001 \\
(0.001)\end{array}$ & $\begin{array}{l}0.000 \\
(0.001)\end{array}$ & $\begin{array}{l}0.000 \\
(0.000)\end{array}$ & $\begin{array}{l}0.000 \\
(0.000)\end{array}$ & $\begin{array}{l}-0.001 \\
(0.000)\end{array}$ & $\begin{array}{l}-0.000 \\
(0.000)\end{array}$ & $\begin{array}{l}-0.000 \\
(0.000)\end{array}$ & $\begin{array}{l}0.000 \\
(0.000)\end{array}$ & $\begin{array}{l}0.001 \\
(0.001)\end{array}$ & $\begin{array}{l}0.001 \\
(0.001)\end{array}$ & $\begin{array}{l}0.001 \\
(0.001)\end{array}$ & $\begin{array}{l}0.001^{* *} \\
(0.000)\end{array}$ \\
\hline Int. 2014 and \% HH Syr. & $\begin{array}{l}0.000 \\
(0.001)\end{array}$ & $\begin{array}{l}-0.000 \\
(0.000)\end{array}$ & $\begin{array}{l}0.000 \\
(0.000)\end{array}$ & $\begin{array}{l}0.000 \\
(0.000)\end{array}$ & $\begin{array}{l}-0.001 \\
(0.000)\end{array}$ & $\begin{array}{l}-0.000 \\
(0.001)\end{array}$ & $\begin{array}{l}-0.000 \\
(0.001)\end{array}$ & $\begin{array}{l}0.000 \\
(0.000)\end{array}$ & $\begin{array}{l}0.001 \\
(0.001)\end{array}$ & $\begin{array}{l}0.001 \\
(0.001)\end{array}$ & $\begin{array}{l}0.001 \\
(0.001)\end{array}$ & $\begin{array}{l}0.000 \\
(0.000)\end{array}$ \\
\hline Int. 2015 and \% HH Syr. & $\begin{array}{l}0.001 \\
(0.001)\end{array}$ & $\begin{array}{l}0.000 \\
(0.001)\end{array}$ & $\begin{array}{l}0.000 \\
(0.001)\end{array}$ & $\begin{array}{l}0.000 \\
(0.000)\end{array}$ & $\begin{array}{l}-0.001 \\
(0.001)\end{array}$ & $\begin{array}{l}-0.000 \\
(0.001)\end{array}$ & $\begin{array}{l}-0.000 \\
(0.001)\end{array}$ & $\begin{array}{l}0.000 \\
(0.000)\end{array}$ & $\begin{array}{l}0.001 \\
(0.001)\end{array}$ & $\begin{array}{l}0.001 \\
(0.001)\end{array}$ & $\begin{array}{l}0.000 \\
(0.001)\end{array}$ & $\begin{array}{l}0.000 \\
(0.000)\end{array}$ \\
\hline Int. 2016 and \% HH Syr. & $\begin{array}{l}0.000 \\
(0.001)\end{array}$ & $\begin{array}{l}-0.000 \\
(0.001)\end{array}$ & $\begin{array}{l}0.000 \\
(0.001)\end{array}$ & $\begin{array}{l}0.000 \\
(0.000)\end{array}$ & $\begin{array}{l}-0.001 \\
(0.001)\end{array}$ & $\begin{array}{l}-0.000 \\
(0.001)\end{array}$ & $\begin{array}{l}-0.000 \\
(0.001)\end{array}$ & $\begin{array}{l}0.000 \\
(0.000)\end{array}$ & $\begin{array}{l}0.000 \\
(0.001)\end{array}$ & $\begin{array}{l}-0.000 \\
(0.001)\end{array}$ & $\begin{array}{l}-0.000 \\
(0.001)\end{array}$ & $\begin{array}{l}0.000 \\
(0.000)\end{array}$ \\
\hline Int. 2017 and \% HH Syr. & $\begin{array}{l}0.000 \\
(0.001)\end{array}$ & $\begin{array}{l}0.000 \\
(0.001)\end{array}$ & $\begin{array}{l}0.000 \\
(0.001)\end{array}$ & $\begin{array}{l}0.000 \\
(0.000)\end{array}$ & $\begin{array}{l}-0.001 \\
(0.001)\end{array}$ & $\begin{array}{l}-0.000 \\
(0.001)\end{array}$ & $\begin{array}{l}0.000 \\
(0.001)\end{array}$ & $\begin{array}{l}0.000 \\
(0.000)\end{array}$ & $\begin{array}{l}0.000 \\
(0.001)\end{array}$ & $\begin{array}{l}0.000 \\
(0.001)\end{array}$ & $\begin{array}{l}-0.000 \\
(0.001)\end{array}$ & $\begin{array}{l}0.000 \\
(0.000)\end{array}$ \\
\hline Controls & & $\mathrm{X}$ & $\mathrm{X}$ & $\mathrm{X}$ & & $\mathrm{X}$ & $\mathrm{X}$ & $\mathrm{X}$ & & $\mathrm{X}$ & $\mathrm{X}$ & $\mathrm{X}$ \\
\hline Locality FE & & & $\mathrm{X}$ & & & & $X$ & & & & $\mathrm{X}$ & \\
\hline Individual FE & & & & $\mathrm{X}$ & & & & $\mathrm{X}$ & & & & $\mathrm{X}$ \\
\hline N (Person-Year Obs.) & 50813 & 50144 & 50144 & 50813 & 50813 & 50144 & 50144 & 50813 & 51126 & 50452 & 50452 & 51126 \\
\hline R-sq. & 0.000 & 0.068 & 0.189 & 0.003 & 0.001 & 0.141 & 0.225 & 0.001 & 0.001 & 0.092 & 0.337 & 0.006 \\
\hline
\end{tabular}

Source: Authors’ calculations based on JLMPS 2016

Notes: ${ }^{*} \mathrm{p}<0.05 ;{ }^{* *} \mathrm{p}<0.01 ;{ }^{* * *} \mathrm{p}<0.001$

Controls include education level, mother's education level, father's education level, father's employment status, age, and age squared Standard errors (in parentheses) clustered at the locality level 


\subsection{Panel models}

One limitation of utilizing retrospective data is that the data lacks variables on some important outcomes including wages ${ }^{27}$ and hours worked. In addition, utilizing retrospective data might produce biased or noisy estimates due to recall challenges. In this section we re-examine the impact of Syrian refugees using the panel data for 2010 and 2016. In this model, we control for individual fixed effects and use only observations for the individuals in both the 2010 and 2016 waves. Since we control for individual fixed effects, the model only includes the 2016 year dummy (2010 is the reference year) and the share of refugees-2016 interaction variable (as well as controls for age). The main limitation of using this model is that it does not allow us to investigate how the effect varies over time as it utilizes only two points in time. In addition, we lack historical data, prior to 2010, to re-test the parallel trend assumption.

Table 4 documents the panel results. The estimates of the impact of refugees are statistically insignificant for employment and unemployment. However, the estimates are significant for job formality, which increases with a larger shock. For each percentage point increase in the share of the locality that is Syrian, the probability of formal employment increases by 0.3 percentage points. ${ }^{28}$ In addition to the positive effect on formality, in the panel models we see a small but significant and positive effect of the shock on hourly wages; a percentage point increase in the share Syrian leads to $0.9 \%$ higher wages in 2016. However, because hours have

\footnotetext{
${ }^{27}$ Around 86\% of employed Jordanians were wage workers in 2016. Given the limited number of non-wage workers we do not analyze them separately.

${ }^{28}$ When estimating unconditional on employment (i.e. treating the non-employed as zeros) and estimating the probability of informal and formal employment, there are negative and insignificant effects of the refugee shock on informal employment and positive and insignificant effects of the refugee shock on formal employment.
} 
(insignificantly) decreased, the monthly wage effect is positive but smaller and insignificant. There are not significant occupation effects. Although the open sector and health and human services sector effects are insignificant, the private sector effect is negative and significant; those who experienced a greater refugee influx locally are less likely to work in the private sector (and therefore more likely to work in the public sector). ${ }^{29}$ Overall, these results suggest no negative effects, but some potential shifts, particularly in terms of sector of work.

${ }^{29}$ As with the shift in formality, when estimating unconditional on employment, there is a negative but insignificant change in private sector employment and a positive but insignificant increase in public sector employment. 
Table 4. Labor market outcomes (fixed effects linear probability and OLS models), men, panel data

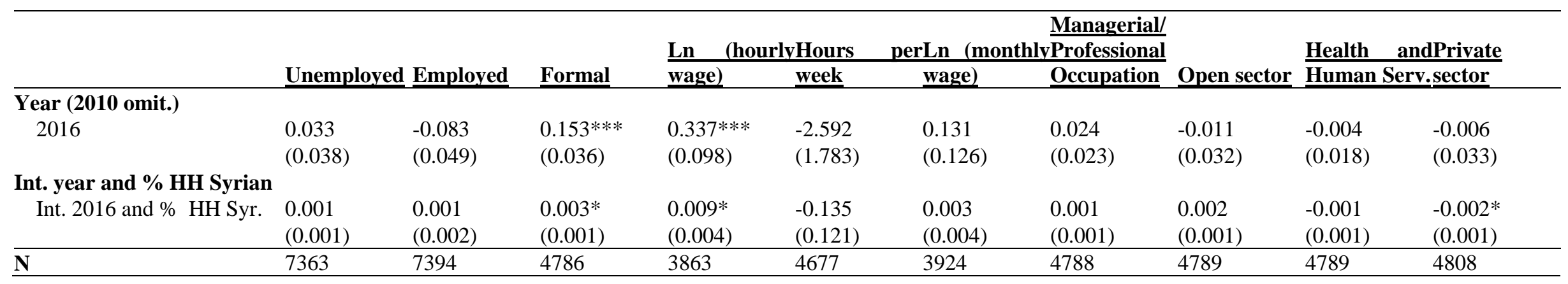

Source: Authors’ calculations based on JLMPS 2010 - JLMPS 2016 panel

Notes: ${ }^{*} \mathrm{p}<0.05 ;{ }^{* *} \mathrm{p}<0.01 ; * * * \mathrm{p}<0.001$

Controlling for age and age squared in year

Standard errors (in parentheses) clustered at the locality level 


\section{Sensitivity Analyses}

This section discusses a series of sensitivity analyses, starting with subgroup analyses by education, sector, and location. These are followed by models assessing potentially differential impacts on new entrants. Subsequently, instrumental variable models are discussed that can account for the potentially endogenous placement of refugees. We then test the sensitivity of our results to the definition of a labor market. Lastly, we present results on the potential role of aid, government spending, and demand for services (specifically education) as a mechanism for the net neutral impacts.

\subsection{Sub-group analyses}

Syrian refugees may be disproportionately competing with less educated Jordanians, those in the private sector, and youth. Using the panel data and 2010 employment characteristics, in Appendix E we re-estimate our models distinguishing between the less and more educated subgroups. The results show no negative and significant results for the less educated. We undertake a similar exercise in Appendix F for those employed in the private versus public sector in 2010. There are not significant negative effects (and there are even some small positive effects) in the private sector. Appendix G investigates whether the result of non-effects may be driven by the capital governorate, Amman, compared to elsewhere. There are consistently no significant negative effects in Amman or other areas. Appendix $\mathrm{H}$ focuses on new entrants and does not find any significant negative effects. Appendix I estimates discrete time hazard models to assess whether new entrants might be delayed in finding employment when they experience a higher intensity refugee influx. There are not significant effects. Overall, the less educated, private sector, and youth populations were not disproportionately affected by the refugee influx. 


\subsection{Instrumental variable models for endogenous placement of refugees}

Since the majority of refugees do not live in camps, they have some choice in where they locate and may select into areas with differential employment outcomes. The main effects of the refugee influx in 2010 in our models generally suggest refugees located in places that were comparable at that time, and with one exception the retrospective tests suggested parallel trends hold. To analyze the sensitivity of our results to this issue, we instrument for the locality share of refugees using, first, the percentage of Syrians and Egyptians from the 2004 census, and, second, the distance from the locality to Za'atari camp in kilometers. The models include the same controls, except we cannot include locality-level fixed effects, since our instrument is at the locality level. As a compromise between the tradeoffs between statistical power and controlling for important geographic differences, we include district-level fixed effects to identify off of locality variation within districts in the share of households that are Syrian. The details of the instruments and results are presented in Appendix J. After accounting for the potential selection of refugees, there are not significant effects of refugee density on the local labor market.

\subsection{Sensitivity of results to definition of a local labor market}

As a final check on our results, we re-estimated our panel models with different definitions of local labor markets. We calculated the share of households Syrian at the sub-district and district levels and used these in the place of locality. The results are presented in Appendix K. Generally, the less-aggregated effects are greater in magnitude and more likely to be significant. They suggest that our main model estimates are identifying the appropriate local labor market, as the results are similar but more likely insignificant at higher levels of aggregation. 


\subsection{Education as a potential labor demand mechanism}

While the Syrian influx could create a labor supply shock, demand for goods and services from refugees, as well as foreign aid and government spending on services, could potentially create additional labor demand, offsetting the labor supply shock. Such a situation is consistent with the overall net neutral results in our models. Appendix L specifically explores potential labor demand created through the education sector, from building new schools or adding shifts to existing schools. The results suggest that such additions do increase employment in health and human services, consistent with the time trend results in Appendix A. Although we are not able to estimate a fully parameterized model distinguishing labor demand and labor supply effects, the results are suggestive of labor demand mechanisms.

\section{Conclusion}

This paper examines the impact of a refugee influx on natives' labor market outcomes. Using individual level panel data from Jordan before and after the Syrian refugee influx, we estimated a variety of difference-in-difference models to study the effects of local labor market shocks on natives' labor market outcomes. An important strength of the analysis, relative to the literature, is the potential in the individual level panel and retrospective data to both control for individual fixed effects and test for parallel trends.

We found that Jordanians living in areas with high concentrations of refugees had no worse labor market outcomes than Jordanians with less exposure to the refugee influx. This result held across unemployment, employment, characteristics of employment (formality, occupation, open sector, health and human services sector, private sector), hours, and wages. Employment and unemployment consistently showed no effects. The panel data results indicated a significant 
increase in formality, hourly (but not monthly) wages, and a shift from the private to public sector for workers with more exposure to the refugee influx.

Our findings contrast with most of the very recent literature on the impact of the Syrian refugee influx, which to date had been limited to evidence from Turkey. Studies in Turkey tended to find negative employment and wage effects, especially on low-skilled Turkish natives (Bagir 2017; Ceritoglu et al. 2017; Del Carpio and Wagner 2015; Tumen 2016), although other studies suggested such results were estimation driven or transitory (Akgündüz, van den Berg, and Hassink 2015; Cengiz and Tekguc 2017). The global literature generally finds a similar mix of no or small specific negative effects (Card 1990; Maystadt and Verwimp 2014; Peri 2016; Ruiz and VargasSilva 2016).

There are several channels that may have ameliorated any potentially negative impact of the massive influx of Syrian refugees. First, it is important to note that the composition of Syrians in Jordan might have played an important role. The Syrians in Jordan are very young (Krafft et al. 2018). Almost half are under the age of 15 . A quarter (23\%) of Syrian refugee households in Jordan have a female head (compared to $14 \%$ of Jordanian households). As a result, only $23 \%$ of Syrian refugees $-45 \%$ of men and $4 \%$ of women — are in the labor force. Only $38 \%$ of men and $3 \%$ of women are employed (Krafft et al. 2018).

Furthermore, in February 2016, the Jordan Compact was signed with the aim of easing Syrian refugees' access to work permits and formalizing their work. The aim of this new system was to create 200,000 new permits. However, the take-up of work permits by Syrians has been very low. According to the Ministry of Labor, by the end of 2017 only 87,141 work permits to Syrians were issued (Ministry of Labour Syrian Refugee Unit 2018). Thus, few Syrians are competing in the (formal) labor market, making their labor supply effect relatively small. 
In addition, despite the massive inflow of Syrian refugees, the number of non-Syrian immigrants has not decreased in Jordan during the same period. According to the 2015 Population Census of Jordan, Jordan hosted an additional 1.6 million non-Syrian foreigners (Department of Statistics (Jordan) 2015a). Even before the refugee influx, economic immigrants in Jordan have tended to be on average low-skilled relative to Jordanians and many occupations in the Jordanian labor market are reserved for Jordanian citizens alone, in particular in the public sector. Economic immigrants are confined to the private sector and mostly in informal employment with no job contract (Wahba 2014). As a result of this labor segmentation, Syrians mainly compete with economic immigrants in the informal sector. This limits the competition between refugees and Jordanians. Indeed, Malaeb and Wahba (2018) controlling for the sorting of Syrians and economic immigrants, found that economic immigrants were more likely to be pushed into informal employment and worked fewer hours as a result of the influx of refugees.

The inflow of foreign aid has also been a potential mechanism for creating labor demand among Jordanians. To help address the needs of the Syrian refugees, Jordan has received foreign aid from multiple sources, including country donors and UN agencies. In 2016, for example, Jordan received \$1.65 billion in assistance towards the Jordan Response Plan for the Syria Crisis (Ministry of Planning and International Cooperation 2017). Net Official Aid (ODA) received as a share of GNI has increased from 3.6\% in 2010, before the Syrian conflict, to 7.3\% in 2017 (World Bank 2019). UN agencies directly provide aid to Syrian refugees in the forms of service delivery or aid projects through nongovernmental organizations. For example, as of August 2016 the World Food Program provided food vouchers of equivalent to $\$ 28.2$ per refugee per month for 95 thousand refugees in camps and food vouchers equivalent to \$14.1 per refugee per month to 425 thousand refugees in host communities (World Food Programme 2016). Aid is also channeled to 
the Jordanian government, to help offset the budget deficit, finance public projects, and support country systems and services nationwide. For example, with assistance from partners, the Jordanian Ministry of Education set up an Education Management Information System and a GIS school mapping tool to aid in infrastructure planning (Ministry of Planning and International Cooperation 2017). Both direct assistance to refugees and aid to the government can create labor demand, the latter disproportionately in the government and health and human services sectors.

The Jordan Compact, which included provisions to reform Jordan's labor policy to grant Syrian refugees formal work permits, also included aid and trade concessions. Specifically, the EU committed to enhance access of Jordanian exports to EU countries, temporarily relaxing the rules of origin, potentially creating labor demand in tradeables (European Commission 2016).

The increase in demand for public services, in particular education and health, has resulted in the Jordanian government increasing the provision of those services, which in turn increased the demand for workers (almost exclusively Jordanians) in those sectors. For example, 209 schools added double shifts in host communities and 45 schools were established in refugee camps, employing Jordanian teachers (Ministry of Planning and International Cooperation 2017). Indeed, as shown in Appendix L, the percentage of new schools/new shifts built and shifts added for Syrians is associated with a rise in health and human services employment.

Although we are not directly evaluating the impact of providing legal work opportunities to refugees, our results do suggest that such a policy may be compatible with maintaining work opportunities for natives as well. The inflow of foreign aid to Jordan to assist with some of the refugees' needs, as well as the conditions of the Jordan Compact, which included aid and trade concessions as well as support for Jordanians' employment, may have played an important role in creating labor demand for Jordanians. Further research to better understand the impact of the 
Jordan Compact and work permits will be important to inform the planned Global Compact on Refugees. Specifically, such research could inform the importance of aid and other support for host countries as well as how to include refugees in local labor markets (UNHCR 2018b). 


\section{References}

Ajluni, Salem, and Mary Kawar. 2014. "The Impact of the Syrian Refugee Crisis on the Labour Market in Jordan: A Preliminary Analysis.” International Labour Organization.

Akgündüz, Yusuf Emre, Marcel van den Berg, and Wolter Hassink. 2015. "The Impact of Refugee Crises on Host Labor Markets: The Case of the Syrian Refugee Crisis in Turkey.” IZA Discussion Paper Series No. 8841.

Alix-Garcia, Jennifer, Sarah Walker, Anne Bartlett, Harun Onder, and Apurva Sanghi. 2018. "Do Refugee Camps Help or Hurt Hosts? The Case of Kakuma, Kenya.” Journal of Development Economics 130: 66-83.

Amer, Mona. 2018. “School-to-Work Transition in Jordan, 2010-2016.” Economic Research Forum Working Paper Series No. 1196. Cairo, Egypt.

Assaad, Ragui, ed. 2014. The Jordanian Labour Market in the New Millenium. Oxford, UK: Oxford University Press.

Assaad, Ragui, and Caroline Krafft. 2016. "Labor Market Dynamics and Youth Unemployment in the Middle East and North Africa: Evidence from Egypt, Jordan and Tunisia.” Economic Research Forum Working Paper Series No. 993. Cairo, Egypt.

Assaad, Ragui, Caroline Krafft, and Caitlyn Keo. 2018. "The Composition of Labor Supply and Its Evolution from 2010 to 2016 in Jordan.” Economic Research Forum Working Paper Series No. 1183. Cairo, Egypt.

Assaad, Ragui, Caroline Krafft, and Shaimaa Yassin. 2018. "Comparing Retrospective and Panel Data Collection Methods to Assess Labor Market Dynamics.” IZA Journal of Development and Migration 8 (17): 1-34.

Bagir, Yusuf. 2017. "Impact of the Syrian Refugee Influx on Turkish Native Workers: An Ethnic Enclave Approach.” MPRA Paper No. 80803. Munich, Germany.

Borjas, George J., and Joan Monras. 2017. "The Labor Market Consequences of Refugee Supply Shocks.” Economic Policy 32 (91): 361-413.

Card, David. 1990. “The Impact of the Mariel Boatlift on the Miami Labor Market.” ILR Review 43 (2): 245-257.

Cengiz, Doruk, and Hasan Tekguc. 2017. "Is It Merely A Labor Supply Shock? Impacts of Syrian Migrants on Local Economies in Turkey.” In ASSA 2018 Annual Meeting, 1-68.

Ceritoglu, Evren, H. Burcu Gurcihan Yunculer, Huzeyfe Torun, and Semih Tumen. 2017. “The Impact of Syrian Refugees on Natives’ Labor Market Outcomes in Turkey: Evidence from a Quasi-Experimental Design.” IZA Journal of Labor Policy 6 (1): 1-28.

Clemens, Michael, and Jennifer Hunt. 2017. "The Labor Market Effects of Refugee Waves: Reconciling Conflicting Results.” NBER Working Paper Series No. 23433. Cambridge, MA.

Cookle, Mikki. 2017. "Implications of the Syrian Refugee Influx on the Jordanian Labor Market: Trends Analysis across Jordan’s Twelve Governorates, 2007-2014.” University of Minnesota.

Del Carpio, Ximena V., and Mathis Wagner. 2015. "The Impact of Syrian Refugees on the Turkish Economy: Regional Labour Market Effects.” World Bank Policy Research Paper No. 7402. Washington, DC.

Department of Statistics (Jordan). 2004. “Table 5.1 Distribution of Population Living in Jordan 15+ Years of Age by Economic Activity Status, Sex, Nationality, Urban-Rural, and Governorates." Population and Housing Census 2005. Retrieved March 9, 2019. http://www.dos.gov.jo/dos_home_e/main/population/census2004/group5/table_51.pdf.

_. 2015a. "Table 8.1: Distribution of Non-Jordanian Population Living in Jordan by Sex, 
Nationality, Urban/ Rural and Governorate.” Population and Housing Census 2015. Retrieved November 3, 2017. http://www.dos.gov.jo/dos_home_a/main/population/census2015/Non-Jordanians/Nonjordanian_8.1.pdf.

. 2015b. "Table 5.7: Distribution of Population Living in Jordan Aged (15 Years and above) by Economic Activity Status, Sex, Nationality, Urban/Rural and Governorate.” Population and Housing Census 2015. Retrieved March 8, 2019. http://www.dos.gov.jo/dos_home_a/main/population/census2015/WorkForce/WorkingForc e_5.7.pdf.

Dunmore, Charlie. 2016. “Work Permit Boost Gives Hope to Syrian Refugees in Jordan.” UNHCR News and Stories (April 19).

Dustmann, Christian, Uta Schönberg, and Jan Stuhler. 2016. "The Impact of Immigration: Why Do Studies Reach Such Different Results?” Journal of Economic Perspectives 30 (4): 31-56. European Commission. 2016. "Decision No 1/2016 of the EU-Jordan Association Committee." Official Journal of the European Union 59. European Union: 6-38.

Fakih, Ali, and May Ibrahim. 2015. "The Impact of Syrian Refugees on the Labor Market in Neighboring Countries: Empirical Evidence from Jordan.” Defence and Peace Economics 2694: $1-23$.

Francis, Alexandra. 2015. “Jordan’s Refugee Crisis.” Washington, DC: Carnegie Endowment for International Peace.

International Rescue Committee. 2017. "In Search of Work: Creating Jobs for Syrian Refugees: A Case Study of the Jordan Compact.” London, UK: International Rescue Committee.

Kelberer, Victoria. 2017. "The Work Permit Initiative for Syrian Refugees in Jordan: Implications for Policy and Practice.” Boston Consortium of Arab Region Studies Policy Paper. Boston, MA.

Kerr, Sari Pekkala, and William R. Kerr. 2011. "Economic Impacts of Immigration: A Survey.” NBER Working Paper Series No. 16736. Cambridge, MA.

Krafft, Caroline, and Ragui Assaad. 2018. "Introducing the Jordan Labor Market Panel Survey 2016.” Economic Research Forum Working Paper Series No. 1186. Cairo, Egypt.

Krafft, Caroline, Maia Sieverding, Colette Salemi, and Caitlyn Keo. 2018. "Syrian Refugees in Jordan: Demographics, Livelihoods, Education, and Health.” Economic Research Forum Working Paper Series No. 1184. Cairo, Egypt.

Ledwith, Alison. 2014. “Zaatari: The Instant City.” Boston, MA: Affordable Housing Institute.

Malaeb, Bilal, and Jackline Wahba. 2018. "Impact of Refugees on Immigrants' Labor Market Outcomes.” Economic Research Forum Working Paper Series No. 1194. Cairo, Egypt.

Maystadt, Jean-François, and Philip Verwimp. 2014. "Winners and Losers among a RefugeeHosting Population.” Economic Development and Cultural Change 62 (4): 769-809.

Ministry of Labour Syrian Refugee Unit. 2018. "Syrian Refugee Unit Work Permit Progress Report January 2018.” Amman, Jordan.

Ministry of Planning and International Cooperation. 2017. "Jordan Response Plan for the Syria Crisis: 2018-2020.” Amman, Jordan.

OAMDI. 2018a. "Labor Market Panel Surveys (LMPS). Version 3.4 of Licensed Data Files; JLMPS 2010.” Cairo, Egypt: Economic Research Forum.

—. 2018b. "Labor Market Panel Surveys (LMPS). Version 1.1 of Licensed Data Files; JLMPS 2016.” Cairo, Egypt: Economic Research Forum.

Oddone, Elisa. 2014. “Azraq Refugee Camp Officially Opened.” Jordan Times (April 30). 
Peri, Giovanni. 2016. "Immigrants, Productivity, and Labor Markets.” Journal of Economic Perspectives 30 (4): 3-30.

Peri, Giovanni, and Vasil Yasenov. 2017. "The Labor Market Effects of a Refugee Wave: Synthetic Control Method Meets the Mariel Boatlift.” IZA Discussion Paper Series No. 10605. Bonn, Germany.

Razzaz, Susan. 2017. "A Challenging Market Becomes More Challenging: Jordanian Workers, Migrant Workers, and Refugees.” Beirut: International Labour Organization.

Reuters. 2012. “Jordan Opens Camp to Deal with More Syrian Refugees.” Reuters (July 29).

Ruiz, Isabel, and Carlos Vargas-Silva. 2016. "The Labor Market Consequences of Hosting Refugees.” The Journal of Economic Geography 3 (1): 667-694.

Stave, Svein Erik, and Solveig Hillesund. 2015. "Impact of Syrian Refugees on the Jordanian Labour Market.” International Labour Organization.

Tumen, Semih. 2016. "The Economic Impact of Syrian Refugees on Host Countries: QuasiExperimental Evidence from Turkey.” American Economic Review 106 (5): 456-460.

UNHCR. 2018a. "Global Trends: Forced Displacement in 2017.” Geneva, Switzerland: UNHCR.

—. 2018b. "UNHCR - Towards a Global Compact on Refugees.” Retrieved June 27, 2018. http://www.unhcr.org/en-us/towards-a-global-compact-on-refugees.html.

— . 2018c. "Situation Syria Regional Refugee Response." Retrieved March 17, 2018. https://data2.unhcr.org/en/situations/syria/location/36.

Wahba, Jackline. 2014. "Immigration, Emigration, and the Labor Market in Jordan." In The Jordanian Labour Market in the New Millennium, edited by Ragui Assaad, 172-188. Oxford, UK: Oxford University Press.

World Bank. 2019. “World Development Indicators.” World Bank Databank. Retrieved March 11, 2019. www.databank.worldbank.org.

World Food Programme. 2016. "WFP Jordan Situation Report \# 13.”

Yassine, Chaimaa. 2013. "Structural Labor Market Transitions and Wage Dispersion in Egypt and Jordan.” Economic Research Forum Working Paper Series No. 753. Economic Research Forum Working Paper Series. Cairo, Egypt. 


\section{ONLINE APPENDICES}

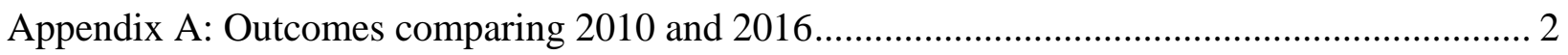

Appendix B: Pooling retrospective data ............................................................................... 5

Appendix C: Results (retrospective and panel) for women .................................................. 12

Appendix D: Cross-sectional model results....................................................................... 20

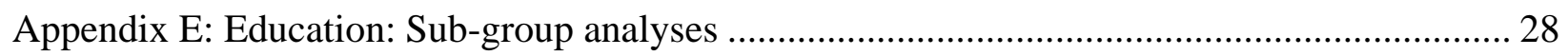

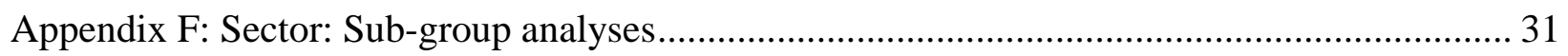

Appendix G: Amman versus elsewhere: Sub-group analyses .............................................. 34

Appendix H: Entrants: Sub-Group Analyses ...................................................................... 37

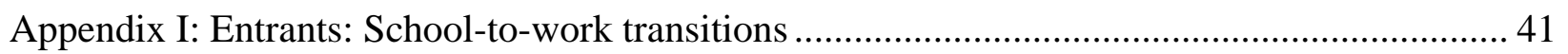

Appendix J: Instrumenting for potential endogenous placement of refugees............................ 45

Appendix K: Varying levels of geographic aggregation ....................................................... 56

Appendix L: New schools and labor demand in education ................................................. 59

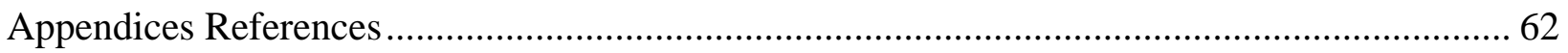




\section{Appendix A: Outcomes comparing 2010 and 2016}

Comparing labor outcomes for Jordanians in 2010 to 2016 can illustrate national trends, which may be linked to perceptions of the impact of refugees, as well as potential mechanisms for impact. Figure 1, for outcomes in percentages or hours, and Figure 2, for log wages, present how national outcomes have changed over time, by sex. The unemployment ratio (percentage of the population unemployed, distinct from the unemployment rate) rose (from 5\% to 7\%) while the employment rate fell even further (from 39\% to 33\%), such that labor force participation (not shown) dropped as well. Among the employed, there are important changes over time that suggest possible mechanisms for the effects of the Syrian influx. Formality increased from $65 \%$ to $66 \%$, the share of workers in managerial or professional activities rose from $29 \%$ to $33 \%$, the share of workers in competitive activities fell from $29 \%$ to $27 \%$, while the share of workers in health and human service activities rose from $17 \%$ to $19 \%$. The private sector shrank from $61 \%$ to $57 \%$ of employment (such that public sector employment rose from $39 \%$ to $43 \%$ of employment). Hours per week fell slightly, from a mean of 46 to 43 , but since hourly wages rose $10 \%$, monthly wages still rose by $5 \%$. These patterns generally held for both men and women. 
Figure 1. Outcomes in percentages or mean hours in 2010 and 2016, by sex, Jordanians ages 15-64
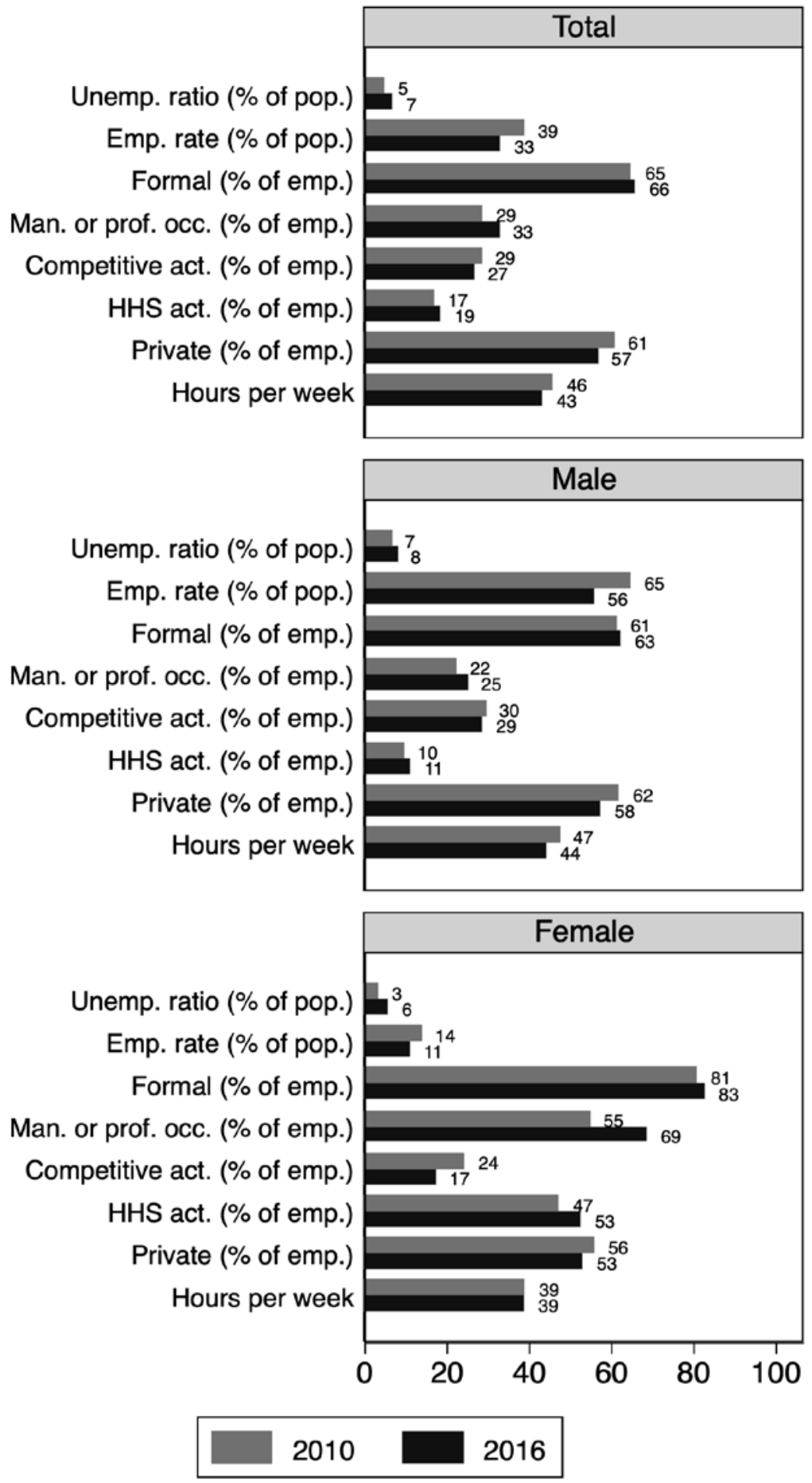

Source: Authors’ calculations based on JLMPS 2010 and 2016 
Figure 2. Log hourly and monthly real wages in 2010 and 2016, by sex, Jordanians ages 1564
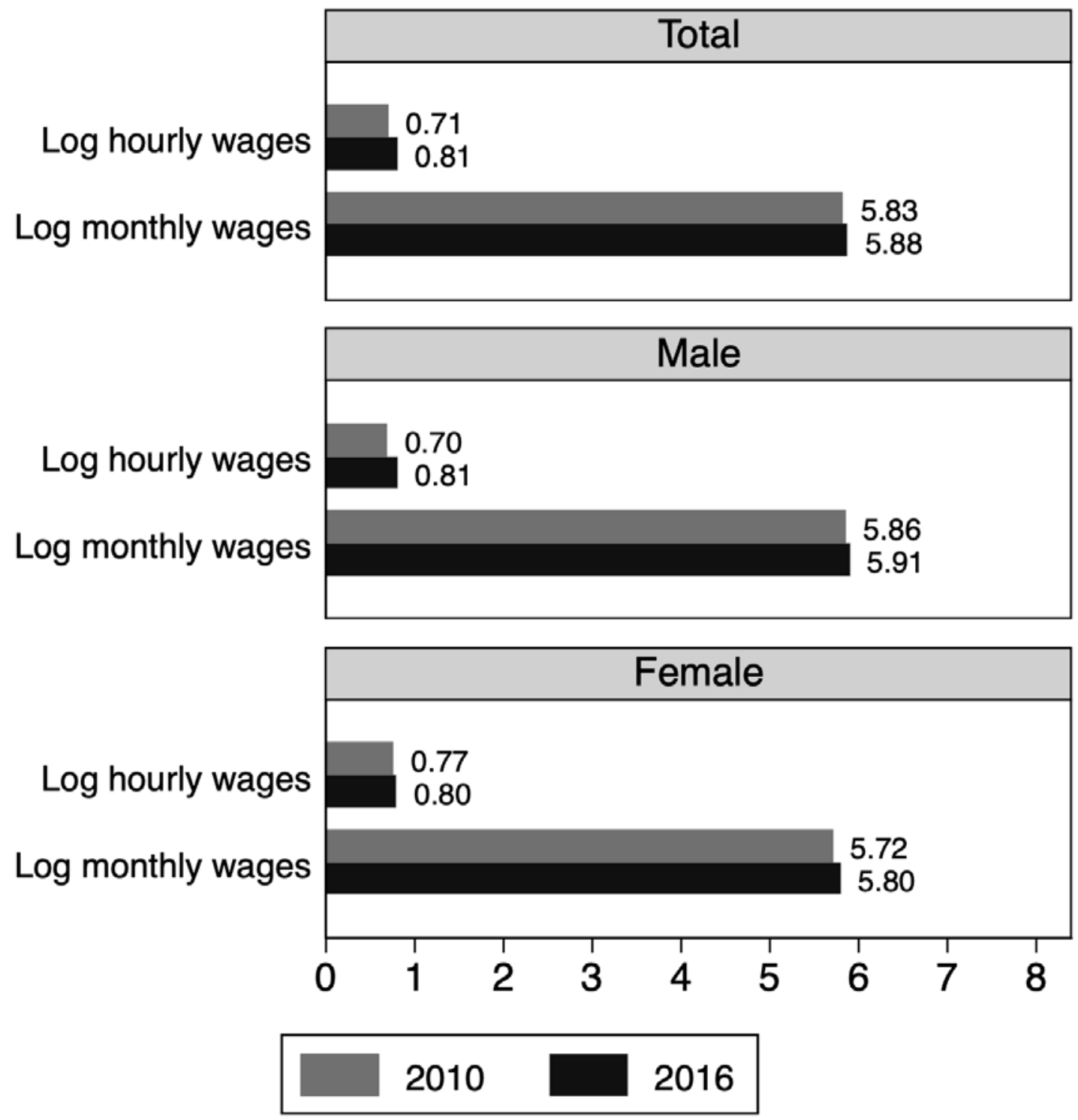

Source: Authors’ calculations based on JLMPS 2010 and 2016 


\section{Appendix B: Pooling retrospective data}

In the retrospective models, we estimate separately the interaction between the Syrian influx and each year, in part because the Syrians arrived over a number of years, and in part because the effects might vary over time. However, this estimation approach may underpower our results. Therefore, in this appendix, we pool "pre-2011" and "2011+" in estimating the central interaction term. The results are presented in Table 1, Table 2, and Table 3. In our preferred specification with individual fixed effects there is only one significant result; a negative effect on the probability of formality in areas that experienced a great influx. However, looking at the year-disaggregated results, this appears to be driven by higher formality in these areas in 2004-2008 (not 2009 or 2010). We therefore prefer our non-pooled results that allow separation of effects and comparison with 2010, immediately pre-influx. 
Table 1. Pooling 2011+: Labor market status (linear probability model), men, retrospective data, 2004-2017

\begin{tabular}{|c|c|c|c|c|c|c|c|c|}
\hline & \multicolumn{4}{|c|}{ Unemployed } & \multicolumn{4}{|c|}{ Employed } \\
\hline \multicolumn{9}{|l|}{ Percentage HH Syrian } \\
\hline \multirow[t]{2}{*}{ Percentage of HH Syr. } & 0.000 & 0.000 & & & -0.001 & -0.001 & & \\
\hline & $(0.001)$ & $(0.001)$ & & & $(0.001)$ & $(0.001)$ & & \\
\hline \multicolumn{9}{|l|}{ Year (2010 omit.) } \\
\hline \multirow[t]{2}{*}{2004} & 0.007 & 0.005 & 0.005 & 0.014 & -0.007 & -0.017 & -0.018 & $-0.606 * * *$ \\
\hline & $(0.007)$ & $(0.007)$ & $(0.007)$ & $(0.016)$ & $(0.012)$ & $(0.010)$ & $(0.010)$ & $(0.021)$ \\
\hline \multirow[t]{2}{*}{2005} & 0.009 & 0.008 & 0.008 & 0.014 & -0.007 & -0.016 & -0.018 & $-0.509 * * *$ \\
\hline & $(0.006)$ & $(0.006)$ & $(0.006)$ & $(0.014)$ & $(0.011)$ & $(0.009)$ & $(0.009)$ & $(0.017)$ \\
\hline \multirow[t]{2}{*}{2006} & 0.006 & 0.004 & 0.004 & 0.009 & -0.007 & -0.013 & -0.013 & $-0.409 * * *$ \\
\hline & $(0.005)$ & $(0.005)$ & $(0.005)$ & $(0.012)$ & $(0.009)$ & $(0.008)$ & $(0.008)$ & $(0.013)$ \\
\hline \multirow[t]{2}{*}{2007} & 0.003 & 0.001 & 0.001 & 0.005 & 0.001 & -0.004 & -0.004 & $-0.302 * * *$ \\
\hline & $(0.004)$ & $(0.004)$ & $(0.004)$ & (0.009) & $(0.007)$ & $(0.006)$ & $(0.007)$ & $(0.011)$ \\
\hline \multirow[t]{2}{*}{2008} & 0.006 & 0.005 & 0.005 & 0.007 & -0.003 & -0.007 & -0.007 & $-0.206 * * *$ \\
\hline & $(0.004)$ & $(0.005)$ & $(0.005)$ & $(0.007)$ & $(0.005)$ & $(0.005)$ & $(0.005)$ & $(0.008)$ \\
\hline \multirow[t]{2}{*}{2009} & $0.007 *$ & $0.006^{*}$ & 0.006 & 0.008 & -0.008 & $-0.010 *$ & $-0.010 *$ & $-0.110 * * *$ \\
\hline & $(0.003)$ & $(0.003)$ & $(0.003)$ & $(0.004)$ & $(0.005)$ & $(0.004)$ & $(0.004)$ & $(0.005)$ \\
\hline \multirow[t]{2}{*}{2011} & 0.011 & 0.010 & 0.012 & 0.009 & -0.013 & -0.013 & -0.013 & $0.092 * * *$ \\
\hline & $(0.008)$ & $(0.008)$ & $(0.008)$ & $(0.008)$ & $(0.016)$ & $(0.013)$ & $(0.013)$ & $(0.013)$ \\
\hline \multirow[t]{2}{*}{2012} & 0.011 & 0.010 & 0.011 & 0.008 & -0.018 & -0.015 & -0.015 & $0.188 * * *$ \\
\hline & (0.009) & (0.009) & (0.009) & $(0.010)$ & $(0.017)$ & $(0.014)$ & $(0.014)$ & $(0.016)$ \\
\hline \multirow[t]{2}{*}{2013} & 0.016 & 0.016 & 0.017 & 0.015 & -0.011 & -0.010 & -0.009 & $0.293 * * *$ \\
\hline & $(0.010)$ & $(0.010)$ & $(0.010)$ & $(0.012)$ & $(0.018)$ & $(0.014)$ & $(0.014)$ & $(0.018)$ \\
\hline \multirow[t]{2}{*}{2014} & 0.019* & $0.020 *$ & $0.021^{*}$ & 0.021 & -0.008 & -0.009 & -0.009 & $0.394 * * *$ \\
\hline & $(0.010)$ & $(0.010)$ & $(0.010)$ & $(0.013)$ & $(0.018)$ & $(0.014)$ & $(0.014)$ & $(0.019)$ \\
\hline \multirow[t]{2}{*}{2015} & 0.019 & 0.020 & $0.022 *$ & 0.024 & -0.002 & -0.004 & -0.003 & $0.498 * * *$ \\
\hline & $(0.010)$ & $(0.010)$ & $(0.010)$ & $(0.015)$ & (0.019) & $(0.014)$ & $(0.014)$ & $(0.022)$ \\
\hline \multirow[t]{2}{*}{2016} & 0.013 & 0.015 & 0.017 & 0.021 & 0.007 & 0.003 & 0.004 & $0.603 * * *$ \\
\hline & $(0.010)$ & $(0.010)$ & $(0.010)$ & $(0.017)$ & (0.019) & $(0.015)$ & $(0.015)$ & $(0.025)$ \\
\hline \multirow[t]{2}{*}{2017} & 0.012 & 0.015 & 0.017 & 0.022 & 0.007 & -0.012 & -0.011 & $0.684 * * *$ \\
\hline & $(0.010)$ & $(0.010)$ & $(0.010)$ & (0.019) & (0.019) & $(0.015)$ & $(0.015)$ & $(0.027)$ \\
\hline
\end{tabular}


Int. 2011+ and \% HH Syr.

Int. 2011+ and \% HH Syr.

Controls

Locality FE

Individual FE

N (Person-Year Obs.)

-0.001
$(0.001)$

$-0.001-0.001$

$(0.001)$

$-0.001$

0.002

$(0.001)$

0.002

(0.001)

$\mathrm{X}$

$\mathrm{X}$
$\mathrm{X}$

$\mathrm{X}$

$\mathrm{X}$

$\mathrm{X}$

$\mathrm{X}$

R-sq.

96543

94889

$\mathrm{X}$

94889

96543

96543

$0.065 \quad 0.002$

0.001

94889

94889

$\mathrm{X}$

96543

Source: Authors’ calculations based on JLMPS 2016

Notes: ${ }^{*} \mathrm{p}<0.05 ; * * \mathrm{p}<0.01 ; * * * \mathrm{p}<0.001$

Controls include education level, mother's education level, father's education level, father's employment status, age, and age squared Standard errors (in parentheses) clustered at the locality level 
Table 2. Pooling 2011+: Job formality and occupation (linear probability model), employed men, retrospective data, 20042017

\begin{tabular}{|c|c|c|c|c|c|c|c|c|}
\hline \multirow{2}{*}{\multicolumn{9}{|c|}{ Managerial/Professional Occupation. }} \\
\hline & & & & & & & & \\
\hline Percentage of HH Syr. & $\begin{array}{l}-0.002 \\
(0.002)\end{array}$ & $\begin{array}{l}-0.003 \\
(0.002)\end{array}$ & & & $\begin{array}{l}0.003^{*} \\
(0.001)\end{array}$ & $\begin{array}{l}0.001 \\
(0.001)\end{array}$ & & \\
\hline Year (2010 omit.) & & & & & & & & \\
\hline 2004 & $\begin{array}{l}-0.038^{* * *} \\
(0.010)\end{array}$ & $\begin{array}{l}-0.036^{* * *} \\
(0.010)\end{array}$ & $\begin{array}{l}-0.025^{*} \\
(0.010)\end{array}$ & $\begin{array}{l}-0.039 * * * \\
(0.010)\end{array}$ & $\begin{array}{l}-0.022 * \\
(0.009)\end{array}$ & $\begin{array}{l}-0.002 \\
(0.006)\end{array}$ & $\begin{array}{l}-0.001 \\
(0.006)\end{array}$ & $\begin{array}{l}-0.004 \\
(0.006)\end{array}$ \\
\hline 2005 & $\begin{array}{l}-0.033^{* * *} \\
(0.009)\end{array}$ & $\begin{array}{l}-0.031^{* * *} \\
(0.009)\end{array}$ & $\begin{array}{l}-0.023^{* *} \\
(0.009)\end{array}$ & $\begin{array}{l}-0.033^{* * *} \\
(0.009)\end{array}$ & $\begin{array}{l}-0.018 * \\
(0.009)\end{array}$ & $\begin{array}{l}-0.001 \\
(0.005)\end{array}$ & $\begin{array}{l}0.000 \\
(0.005)\end{array}$ & $\begin{array}{l}-0.004 \\
(0.005)\end{array}$ \\
\hline 2006 & $\begin{array}{l}-0.028 * * * \\
(0.008)\end{array}$ & $\begin{array}{l}-0.024^{* *} \\
(0.008)\end{array}$ & $\begin{array}{l}-0.019 * \\
(0.007)\end{array}$ & $\begin{array}{l}-0.027^{* * *} \\
(0.007)\end{array}$ & $\begin{array}{l}-0.019 * \\
(0.008)\end{array}$ & $\begin{array}{l}0.001 \\
(0.004)\end{array}$ & $\begin{array}{l}0.003 \\
(0.004)\end{array}$ & $\begin{array}{l}-0.003 \\
(0.005)\end{array}$ \\
\hline 2007 & $\begin{array}{l}-0.018 * \\
(0.007)\end{array}$ & $\begin{array}{l}-0.015^{*} \\
(0.007)\end{array}$ & $\begin{array}{l}-0.013^{*} \\
(0.006)\end{array}$ & $\begin{array}{l}-0.023^{* * *} \\
(0.006)\end{array}$ & $\begin{array}{l}-0.012 * \\
(0.006)\end{array}$ & $\begin{array}{l}0.004 \\
(0.003)\end{array}$ & $\begin{array}{l}0.004 \\
(0.003)\end{array}$ & $\begin{array}{l}-0.001 \\
(0.004)\end{array}$ \\
\hline 2008 & $\begin{array}{l}-0.010 \\
(0.006)\end{array}$ & $\begin{array}{l}-0.005 \\
(0.006)\end{array}$ & $\begin{array}{l}-0.004 \\
(0.006)\end{array}$ & $\begin{array}{l}-0.015^{* *} \\
(0.005)\end{array}$ & $\begin{array}{l}-0.012 * \\
(0.005)\end{array}$ & $\begin{array}{l}0.002 \\
(0.003)\end{array}$ & $\begin{array}{l}0.001 \\
(0.004)\end{array}$ & $\begin{array}{l}-0.001 \\
(0.003)\end{array}$ \\
\hline 2009 & $\begin{array}{l}-0.006 \\
(0.006)\end{array}$ & $\begin{array}{l}-0.002 \\
(0.006)\end{array}$ & $\begin{array}{l}-0.004 \\
(0.006)\end{array}$ & $\begin{array}{l}-0.007 \\
(0.004)\end{array}$ & $\begin{array}{l}-0.007 \\
(0.004)\end{array}$ & $\begin{array}{l}-0.000 \\
(0.003)\end{array}$ & $\begin{array}{l}-0.001 \\
(0.003)\end{array}$ & $\begin{array}{l}-0.001 \\
(0.001)\end{array}$ \\
\hline 2011 & $\begin{array}{l}0.007 \\
(0.010)\end{array}$ & $\begin{array}{l}-0.001 \\
(0.010)\end{array}$ & $\begin{array}{l}-0.003 \\
(0.009)\end{array}$ & $\begin{array}{l}0.015^{* *} \\
(0.005)\end{array}$ & $\begin{array}{l}0.026 * * \\
(0.009)\end{array}$ & $\begin{array}{l}0.002 \\
(0.008)\end{array}$ & $\begin{array}{l}0.006 \\
(0.008)\end{array}$ & $\begin{array}{l}0.002 \\
(0.002)\end{array}$ \\
\hline 2012 & $\begin{array}{l}0.016 \\
(0.010)\end{array}$ & $\begin{array}{l}0.009 \\
(0.010)\end{array}$ & $\begin{array}{l}0.003 \\
(0.009)\end{array}$ & $\begin{array}{l}0.022 * * * \\
(0.006)\end{array}$ & $\begin{array}{l}0.027 * * \\
(0.010)\end{array}$ & $\begin{array}{l}0.001 \\
(0.009)\end{array}$ & $\begin{array}{l}0.006 \\
(0.009)\end{array}$ & $\begin{array}{l}0.003 \\
(0.003)\end{array}$ \\
\hline 2013 & $\begin{array}{l}0.015 \\
(0.010)\end{array}$ & $\begin{array}{l}0.009 \\
(0.010)\end{array}$ & $\begin{array}{l}0.004 \\
(0.010)\end{array}$ & $\begin{array}{l}0.029 * * * \\
(0.007)\end{array}$ & $\begin{array}{l}0.029 * * \\
(0.011)\end{array}$ & $\begin{array}{l}0.005 \\
(0.009)\end{array}$ & $\begin{array}{l}0.009 \\
(0.009)\end{array}$ & $\begin{array}{l}0.004 \\
(0.004)\end{array}$ \\
\hline 2014 & $\begin{array}{l}0.021 * \\
(0.010)\end{array}$ & $\begin{array}{l}0.016 \\
(0.011)\end{array}$ & $\begin{array}{l}0.010 \\
(0.010)\end{array}$ & $\begin{array}{l}0.040^{* * *} \\
(0.009)\end{array}$ & $\begin{array}{l}0.031 * * \\
(0.011)\end{array}$ & $\begin{array}{l}0.006 \\
(0.009)\end{array}$ & $\begin{array}{l}0.011 \\
(0.009)\end{array}$ & $\begin{array}{l}0.006 \\
(0.004)\end{array}$ \\
\hline 2015 & $\begin{array}{l}0.018 \\
(0.011)\end{array}$ & $\begin{array}{l}0.013 \\
(0.012)\end{array}$ & $\begin{array}{l}0.006 \\
(0.011)\end{array}$ & $\begin{array}{l}0.047 * * * \\
(0.010)\end{array}$ & $\begin{array}{l}0.031 * * \\
(0.012)\end{array}$ & $\begin{array}{l}0.001 \\
(0.011)\end{array}$ & $\begin{array}{l}0.007 \\
(0.011)\end{array}$ & $\begin{array}{l}0.007 \\
(0.005)\end{array}$ \\
\hline 2016 & $\begin{array}{l}0.020 \\
(0.012)\end{array}$ & $\begin{array}{l}0.016 \\
(0.012)\end{array}$ & $\begin{array}{l}0.009 \\
(0.012)\end{array}$ & $\begin{array}{l}0.054 * * * \\
(0.011)\end{array}$ & $\begin{array}{l}0.032 * * \\
(0.012)\end{array}$ & $\begin{array}{l}-0.000 \\
(0.011)\end{array}$ & $\begin{array}{l}0.005 \\
(0.010)\end{array}$ & $\begin{array}{l}0.008 \\
(0.006)\end{array}$ \\
\hline 2017 & $\begin{array}{l}0.021 \\
(0.012)\end{array}$ & $\begin{array}{l}0.022 \\
(0.013)\end{array}$ & $\begin{array}{l}0.014 \\
(0.012)\end{array}$ & $\begin{array}{l}0.060 * * * \\
(0.013)\end{array}$ & $\begin{array}{l}0.029 * \\
(0.012)\end{array}$ & $\begin{array}{l}-0.003 \\
(0.011)\end{array}$ & $\begin{array}{l}0.003 \\
(0.011)\end{array}$ & $\begin{array}{l}0.008 \\
(0.007)\end{array}$ \\
\hline $\begin{array}{l}\text { Int. 2011+ and \% HH Syr. } \\
\text { Int. } 2011+\text { and \% HH Syr. }\end{array}$ & -0.001 & 0.000 & 0.000 & $-0.001 *$ & $-0.002 *$ & 0.000 & -0.000 & -0.000 \\
\hline
\end{tabular}




\begin{tabular}{|c|c|c|c|c|c|c|c|c|}
\hline & $(0.001)$ & $(0.001)$ & $(0.001)$ & $(0.000)$ & $(0.001)$ & $(0.001)$ & $(0.001)$ & $(0.000)$ \\
\hline Controls & & $\mathrm{X}$ & $\mathrm{X}$ & $\mathrm{X}$ & & $\mathrm{X}$ & $\mathrm{X}$ & $\mathrm{X}$ \\
\hline Locality FE & & & $X$ & & & & $X$ & \\
\hline Individual FE & & & & $\mathrm{X}$ & & & & $\mathrm{X}$ \\
\hline N (Person-Year Obs.) & 51123 & 50449 & 50449 & 51123 & 50732 & 50065 & 50065 & 50732 \\
\hline R-sq. & 0.002 & 0.099 & 0.209 & 0.006 & 0.003 & 0.555 & 0.588 & 0.001 \\
\hline
\end{tabular}

Source: Authors’ calculations based on JLMPS 2016

Notes: ${ }^{*} \mathrm{p}<0.05 ;{ }^{* *} \mathrm{p}<0.01 ;{ }^{* * *} \mathrm{p}<0.001$

Controls include education level, mother's education level, father's education level, father's employment status, age, and age squared Standard errors (in parentheses) clustered at the locality level 
Table 3. Pooling 2011+: Job sector (linear probability model), employed men, retrospective data 2004-2017

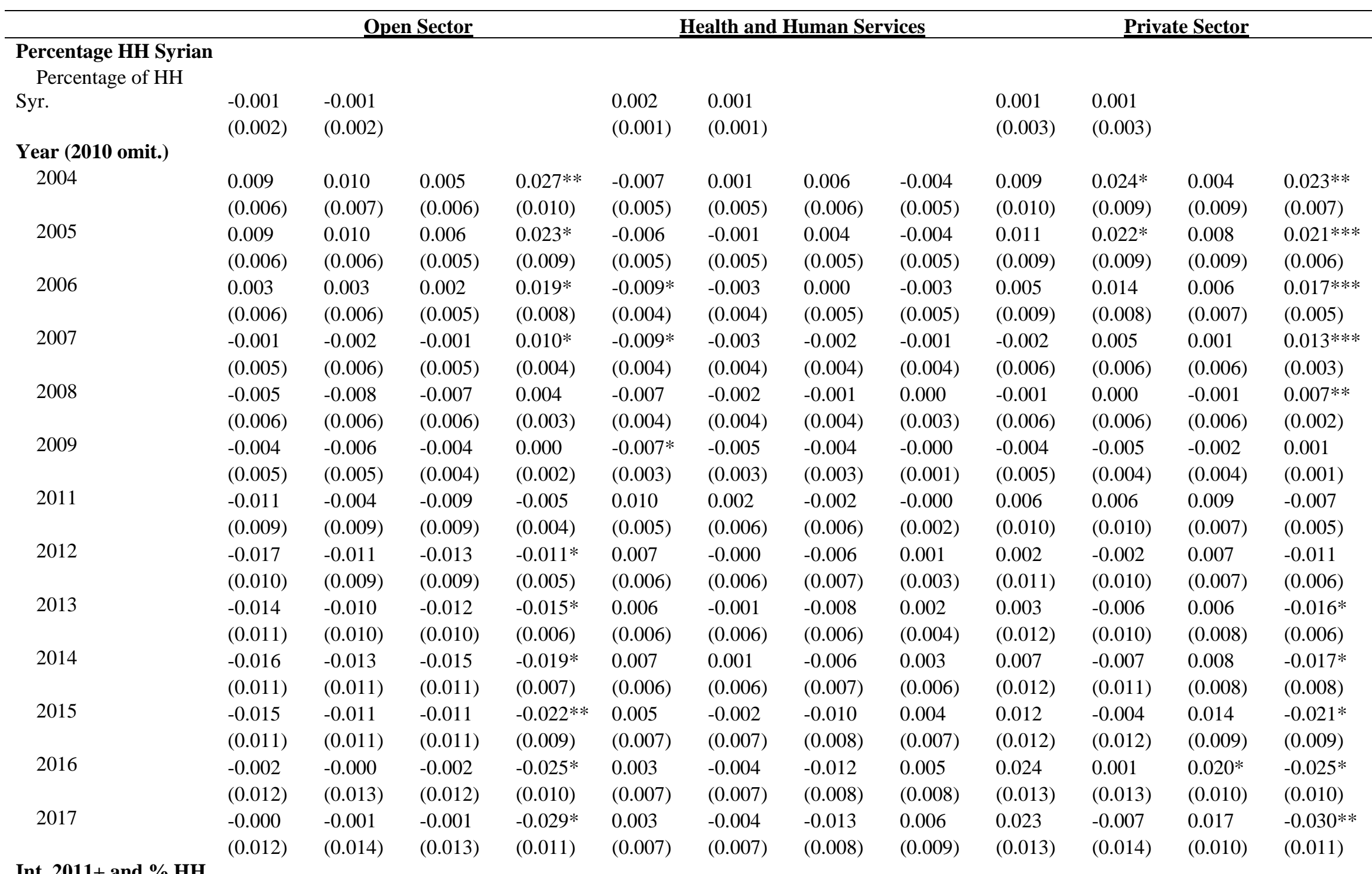

Int. $2011+$ and $\% \mathrm{HH}$

Syr. 


\begin{tabular}{lllllllllllll}
\multicolumn{1}{l}{ Int. 2011+ and \% HH } & & & & & & & & \\
Syr. & 0.001 & 0.000 & 0.001 & 0.000 & -0.001 & -0.000 & 0.000 & 0.000 & -0.000 & -0.001 & -0.001 & 0.000 \\
& $(0.001)$ & $(0.001)$ & $(0.001)$ & $(0.000)$ & $(0.000)$ & $(0.001)$ & $(0.001)$ & $(0.000)$ & $(0.001)$ & $(0.001)$ & $(0.001)$ & $(0.000)$ \\
\hline Controls & & $\mathrm{X}$ & $\mathrm{X}$ & $\mathrm{X}$ & & $\mathrm{X}$ & $\mathrm{X}$ & $\mathrm{X}$ & & $\mathrm{X}$ & $\mathrm{X}$ & $\mathrm{X}$ \\
Locality FE & & & $\mathrm{X}$ & & & & $\mathrm{X}$ & & & & $\mathrm{X}$ \\
Individual FE & & & & $\mathrm{X}$ & & & & $\mathrm{X}$ & & & $\mathrm{X}$ \\
N (Person-Year Obs.) & 50813 & 50144 & 50144 & 50813 & 50813 & 50144 & 50144 & 50813 & 51126 & 50452 & 50452 & 51126 \\
R-sq. & 0.000 & 0.068 & 0.189 & 0.003 & 0.001 & 0.141 & 0.225 & 0.001 & 0.000 & 0.092 & 0.337 & 0.006 \\
\hline
\end{tabular}

Source: Authors’ calculations based on JLMPS 2016

Notes: ${ }^{*} \mathrm{p}<0.05 ;{ }^{* *} \mathrm{p}<0.01 ; * * * \mathrm{p}<0.001$

Controls include education level, mother's education level, father's education level, father's employment status, age, and age squared Standard errors (in parentheses) clustered at the locality level 


\section{Appendix C: Results (retrospective and panel) for women}

In this appendix, we present the retrospective (Table 4, Table 5, and Table 6) and panel (Table 7) models for women. In the fourth (our preferred) specification with individual fixed effects, the parallel trend assumption always holds in the retrospective models for women and none of the refugee influx effects are significant. The panel results show a small but significant increase in formality for women (as for men) in localities that experienced a greater influx. 
Table 4. Labor market status (linear probability model), women, retrospective data, 2004-2017

\begin{tabular}{|c|c|c|c|c|c|c|c|c|}
\hline & $(1)$ & $(2)$ & $(3)$ & $(4)$ & $(5)$ & $(6)$ & $(7)$ & $(8)$ \\
\hline & \multicolumn{4}{|c|}{ Unemployed } & \multicolumn{4}{|c|}{ Employed } \\
\hline \multicolumn{9}{|l|}{ Percentage HH Syrian } \\
\hline Percentage of HH Syr. & $\begin{array}{l}-0.000 \\
(0.001)\end{array}$ & $\begin{array}{l}-0.001 \\
(0.001)\end{array}$ & & & $\begin{array}{l}-0.000 \\
(0.001)\end{array}$ & $\begin{array}{l}-0.000 \\
(0.001)\end{array}$ & & \\
\hline \multicolumn{9}{|l|}{ Year (2010 omit.) } \\
\hline 2004 & $\begin{array}{l}-0.016 * \\
(0.007)\end{array}$ & $\begin{array}{l}-0.012 \\
(0.007)\end{array}$ & $\begin{array}{l}-0.011 \\
(0.007)\end{array}$ & $\begin{array}{l}-0.105^{* * *} \\
(0.014)\end{array}$ & $\begin{array}{l}-0.010 \\
(0.007)\end{array}$ & $\begin{array}{l}-0.010 \\
(0.007)\end{array}$ & $\begin{array}{l}-0.011 \\
(0.007)\end{array}$ & $\begin{array}{l}-0.162 * * * \\
(0.013)\end{array}$ \\
\hline 2005 & $\begin{array}{l}-0.012 \\
(0.007)\end{array}$ & $\begin{array}{l}-0.009 \\
(0.007)\end{array}$ & $\begin{array}{l}-0.008 \\
(0.007)\end{array}$ & $\begin{array}{l}-0.087 * * * \\
(0.013)\end{array}$ & $\begin{array}{l}-0.005 \\
(0.006)\end{array}$ & $\begin{array}{l}-0.007 \\
(0.006)\end{array}$ & $\begin{array}{l}-0.008 \\
(0.006)\end{array}$ & $\begin{array}{l}-0.133^{* * *} \\
(0.011)\end{array}$ \\
\hline 2006 & $\begin{array}{l}-0.012 \\
(0.006)\end{array}$ & $\begin{array}{l}-0.010 \\
(0.006)\end{array}$ & $\begin{array}{l}-0.009 \\
(0.006)\end{array}$ & $\begin{array}{l}-0.071^{* * *} \\
(0.011)\end{array}$ & $\begin{array}{l}-0.004 \\
(0.005)\end{array}$ & $\begin{array}{l}-0.007 \\
(0.005)\end{array}$ & $\begin{array}{l}-0.007 \\
(0.005)\end{array}$ & $\begin{array}{l}-0.107 * * * \\
(0.008)\end{array}$ \\
\hline 2007 & $\begin{array}{l}-0.010 \\
(0.006)\end{array}$ & $\begin{array}{l}-0.007 \\
(0.005)\end{array}$ & $\begin{array}{l}-0.007 \\
(0.005)\end{array}$ & $\begin{array}{l}-0.054^{* * *} \\
(0.009)\end{array}$ & $\begin{array}{l}-0.004 \\
(0.005)\end{array}$ & $\begin{array}{l}-0.007 \\
(0.005)\end{array}$ & $\begin{array}{l}-0.007 \\
(0.005)\end{array}$ & $\begin{array}{l}-0.082 * * * \\
(0.007)\end{array}$ \\
\hline 2008 & $\begin{array}{l}-0.003 \\
(0.004)\end{array}$ & $\begin{array}{l}-0.001 \\
(0.004)\end{array}$ & $\begin{array}{l}-0.002 \\
(0.004)\end{array}$ & $\begin{array}{l}-0.034 * * * \\
(0.006)\end{array}$ & $\begin{array}{l}-0.007 \\
(0.004)\end{array}$ & $\begin{array}{l}-0.008 \\
(0.004)\end{array}$ & $\begin{array}{l}-0.008 \\
(0.004)\end{array}$ & $\begin{array}{l}-0.058^{* * *} \\
(0.006)\end{array}$ \\
\hline 2009 & $\begin{array}{l}-0.002 \\
(0.003)\end{array}$ & $\begin{array}{l}-0.001 \\
(0.003)\end{array}$ & $\begin{array}{l}-0.002 \\
(0.003)\end{array}$ & $\begin{array}{l}-0.018 * * * \\
(0.004)\end{array}$ & $\begin{array}{l}-0.003 \\
(0.004)\end{array}$ & $\begin{array}{l}-0.004 \\
(0.004)\end{array}$ & $\begin{array}{l}-0.004 \\
(0.004)\end{array}$ & $\begin{array}{l}-0.030 * * * \\
(0.004)\end{array}$ \\
\hline 2011 & $\begin{array}{l}0.004 \\
(0.003)\end{array}$ & $\begin{array}{l}0.005 \\
(0.003)\end{array}$ & $\begin{array}{l}0.005 \\
(0.003)\end{array}$ & $\begin{array}{l}0.021^{* * *} \\
(0.004)\end{array}$ & $\begin{array}{l}-0.000 \\
(0.002)\end{array}$ & $\begin{array}{l}0.002 \\
(0.002)\end{array}$ & $\begin{array}{l}0.002 \\
(0.002)\end{array}$ & $\begin{array}{l}0.025^{* * *} \\
(0.003)\end{array}$ \\
\hline 2012 & $\begin{array}{l}0.003 \\
(0.004)\end{array}$ & $\begin{array}{l}0.006 \\
(0.004)\end{array}$ & $\begin{array}{l}0.006 \\
(0.004)\end{array}$ & $\begin{array}{l}0.036^{* * * *} \\
(0.006)\end{array}$ & $\begin{array}{l}0.004 \\
(0.003)\end{array}$ & $\begin{array}{l}0.010^{* *} \\
(0.003)\end{array}$ & $\begin{array}{l}0.010^{* *} \\
(0.003)\end{array}$ & $\begin{array}{l}0.055^{* * *} \\
(0.005)\end{array}$ \\
\hline 2013 & $\begin{array}{l}0.006 \\
(0.004)\end{array}$ & $\begin{array}{l}0.009 * \\
(0.004)\end{array}$ & $\begin{array}{l}0.008 \\
(0.004)\end{array}$ & $\begin{array}{l}0.055^{* * *} \\
(0.007)\end{array}$ & $\begin{array}{l}0.008^{*} \\
(0.004)\end{array}$ & $\begin{array}{l}0.015^{* * * *} \\
(0.004)\end{array}$ & $\begin{array}{l}0.016^{* * *} \\
(0.004)\end{array}$ & $\begin{array}{l}0.084^{* * * *} \\
(0.008)\end{array}$ \\
\hline 2014 & $\begin{array}{l}0.009 \\
(0.006)\end{array}$ & $\begin{array}{l}0.014^{*} \\
(0.006)\end{array}$ & $\begin{array}{l}0.013^{*} \\
(0.006)\end{array}$ & $\begin{array}{l}0.075^{* * * *} \\
(0.010)\end{array}$ & $\begin{array}{l}0.008 \\
(0.005)\end{array}$ & $\begin{array}{l}0.019 * * * \\
(0.005)\end{array}$ & $\begin{array}{l}0.020 * * * \\
(0.005)\end{array}$ & $\begin{array}{l}0.110 * * * \\
(0.010)\end{array}$ \\
\hline 2015 & $\begin{array}{l}0.011 \\
(0.007)\end{array}$ & $\begin{array}{l}0.016^{*} \\
(0.007)\end{array}$ & $\begin{array}{l}0.016^{*} \\
(0.007)\end{array}$ & $\begin{array}{l}0.093 * * * \\
(0.013)\end{array}$ & $\begin{array}{l}0.015^{*} \\
(0.006)\end{array}$ & $\begin{array}{l}0.026 * * * \\
(0.006)\end{array}$ & $\begin{array}{l}0.027 * * * \\
(0.006)\end{array}$ & $\begin{array}{l}0.140^{* * *} \\
(0.013)\end{array}$ \\
\hline 2016 & $\begin{array}{l}0.010 \\
(0.007)\end{array}$ & $\begin{array}{l}0.016 * \\
(0.008)\end{array}$ & $\begin{array}{l}0.016 * \\
(0.008)\end{array}$ & $\begin{array}{l}0.108^{* * * *} \\
(0.014)\end{array}$ & $\begin{array}{l}0.021 * * \\
(0.007)\end{array}$ & $\begin{array}{l}0.035 * * * \\
(0.007)\end{array}$ & $\begin{array}{l}0.036^{* * *} \\
(0.007)\end{array}$ & $\begin{array}{l}0.171^{* * *} \\
(0.015)\end{array}$ \\
\hline 2017 & $\begin{array}{l}0.010 \\
(0.007)\end{array}$ & $\begin{array}{l}0.016^{*} \\
(0.007)\end{array}$ & $\begin{array}{l}0.015^{*} \\
(0.008)\end{array}$ & $\begin{array}{l}0.121^{* * *} \\
(0.015)\end{array}$ & $\begin{array}{l}0.023 * * \\
(0.008)\end{array}$ & $\begin{array}{l}0.035 * * * \\
(0.008)\end{array}$ & $\begin{array}{l}0.036^{* * *} \\
(0.007)\end{array}$ & $\begin{array}{l}0.193^{* * *} \\
(0.017)\end{array}$ \\
\hline Int. year and \% HH Syr. & & & & & & & & \\
\hline Int. 2004 and \% HH Syr. & $\begin{array}{l}0.000 \\
(0.001)\end{array}$ & $\begin{array}{l}0.000 \\
(0.001)\end{array}$ & $\begin{array}{l}0.000 \\
(0.001)\end{array}$ & $\begin{array}{l}0.001 \\
(0.000)\end{array}$ & $\begin{array}{l}-0.001 \\
(0.001)\end{array}$ & $\begin{array}{l}-0.001 \\
(0.001)\end{array}$ & $\begin{array}{l}-0.001 \\
(0.001)\end{array}$ & $\begin{array}{l}-0.000 \\
(0.001)\end{array}$ \\
\hline Int. 2005 and \% HH Syr. & 0.000 & -0.000 & 0.000 & 0.000 & -0.001 & -0.001 & -0.001 & -0.000 \\
\hline
\end{tabular}




\begin{tabular}{|c|c|c|c|c|c|c|c|c|}
\hline & $(1)$ & $(2)$ & $(3)$ & (4) & (5) & (6) & $(7)$ & $(8)$ \\
\hline & \multicolumn{4}{|c|}{ Unemployed } & \multicolumn{4}{|c|}{ Employed } \\
\hline \multirow{3}{*}{ Int. 2006 and \% HH Syr. } & $(0.001)$ & $(0.001)$ & $(0.001)$ & $(0.000)$ & $(0.001)$ & $(0.001)$ & $\overline{(0.001)}$ & $(0.001)$ \\
\hline & 0.000 & 0.000 & 0.000 & 0.000 & -0.001 & -0.000 & -0.000 & -0.000 \\
\hline & $(0.000)$ & $(0.000)$ & $(0.000)$ & $(0.001)$ & $(0.000)$ & $(0.000)$ & $(0.000)$ & $(0.000)$ \\
\hline \multirow[t]{2}{*}{ Int. 2007 and \% HH Syr. } & 0.000 & -0.000 & -0.000 & 0.000 & -0.000 & -0.000 & -0.000 & -0.000 \\
\hline & $(0.000)$ & $(0.000)$ & $(0.000)$ & $(0.000)$ & $(0.001)$ & $(0.000)$ & $(0.000)$ & $(0.000)$ \\
\hline \multirow[t]{2}{*}{ Int. 2008 and \% HH Syr. } & -0.000 & -0.000 & -0.000 & -0.000 & -0.000 & -0.000 & -0.000 & -0.000 \\
\hline & $(0.000)$ & $(0.000)$ & $(0.000)$ & $(0.000)$ & $(0.000)$ & $(0.000)$ & $(0.000)$ & $(0.000)$ \\
\hline \multirow[t]{2}{*}{ Int. 2009 and \% HH Syr. } & -0.000 & -0.000 & -0.000 & -0.000 & -0.000 & -0.000 & -0.000 & -0.000 \\
\hline & $(0.000)$ & $(0.000)$ & $(0.000)$ & $(0.000)$ & $(0.000)$ & $(0.000)$ & $(0.000)$ & $(0.000)$ \\
\hline \multirow[t]{2}{*}{ Int. 2011 and \% HH Syr. } & 0.000 & 0.000 & 0.000 & 0.000 & 0.000 & -0.000 & -0.000 & -0.000 \\
\hline & $(0.000)$ & $(0.000)$ & $(0.000)$ & $(0.000)$ & $(0.000)$ & $(0.000)$ & $(0.000)$ & $(0.000)$ \\
\hline \multirow[t]{2}{*}{ Int. 2012 and \% HH Syr. } & 0.000 & 0.000 & 0.000 & 0.000 & -0.000 & -0.000 & -0.000 & -0.000 \\
\hline & $(0.000)$ & $(0.000)$ & $(0.000)$ & $(0.000)$ & $(0.000)$ & $(0.000)$ & $(0.000)$ & $(0.000)$ \\
\hline \multirow[t]{2}{*}{ Int. 2013 and \% HH Syr. } & 0.000 & 0.000 & 0.000 & -0.000 & -0.000 & -0.000 & -0.000 & -0.001 \\
\hline & $(0.000)$ & $(0.000)$ & $(0.000)$ & $(0.000)$ & $(0.000)$ & $(0.000)$ & $(0.000)$ & $(0.000)$ \\
\hline \multirow[t]{2}{*}{ Int. 2014 and \% HH Syr. } & 0.000 & 0.000 & 0.000 & -0.000 & -0.000 & -0.000 & -0.000 & -0.001 \\
\hline & $(0.000)$ & $(0.000)$ & $(0.000)$ & $(0.000)$ & $(0.000)$ & $(0.000)$ & $(0.000)$ & $(0.000)$ \\
\hline \multirow[t]{2}{*}{ Int. 2015 and \% HH Syr. } & 0.000 & -0.000 & -0.000 & -0.000 & -0.000 & -0.000 & -0.000 & -0.001 \\
\hline & $(0.000)$ & $(0.000)$ & $(0.000)$ & $(0.001)$ & $(0.000)$ & $(0.000)$ & $(0.000)$ & $(0.000)$ \\
\hline \multirow[t]{2}{*}{ Int. 2016 and \% HH Syr. } & 0.001 & 0.000 & 0.000 & 0.000 & -0.000 & -0.000 & -0.000 & -0.001 \\
\hline & $(0.001)$ & $(0.001)$ & $(0.001)$ & $(0.001)$ & $(0.001)$ & $(0.001)$ & $(0.001)$ & $(0.001)$ \\
\hline \multirow[t]{2}{*}{ Int. 2017 and \% HH Syr. } & 0.000 & 0.000 & 0.000 & 0.000 & -0.000 & -0.000 & -0.000 & -0.001 \\
\hline & $(0.001)$ & $(0.001)$ & $(0.001)$ & $(0.001)$ & $(0.001)$ & $(0.001)$ & $(0.001)$ & $(0.001)$ \\
\hline Controls & & $\mathrm{X}$ & $\mathrm{X}$ & $\mathrm{X}$ & & $\mathrm{X}$ & $\mathrm{X}$ & $\mathrm{X}$ \\
\hline Locality FE & & & $\mathrm{X}$ & & & & $X$ & \\
\hline Individual FE & & & & $\mathrm{X}$ & & & & $\mathrm{X}$ \\
\hline N (Person-Year Obs.) & 97581 & 96367 & 96367 & 97581 & 97581 & 96367 & 96367 & 97581 \\
\hline R-sq. & 0.002 & 0.066 & 0.117 & 0.027 & 0.002 & 0.127 & 0.171 & 0.054 \\
\hline
\end{tabular}

Source: Authors’ calculations based on JLMPS 2016

Notes: ${ }^{*} \mathrm{p}<0.05 ;{ }^{* *} \mathrm{p}<0.01 ;{ }^{* * *} \mathrm{p}<0.001$

Controls include education level, mother's education level, father's education level, father's employment status, age, and age squared Standard errors (in parentheses) clustered at the locality level 
Table 5. Job formality and occupation (linear probability model), employed women, retrospective data, 2004-2017

\begin{tabular}{|c|c|c|c|c|c|c|c|c|}
\hline & $(1)$ & $(2)$ & $(3)$ & $(4)$ & $(5)$ & $(6)$ & $(7)$ & $(8)$ \\
\hline & \multicolumn{4}{|c|}{ Formal } & \multicolumn{4}{|c|}{ Managerial/Professional Occupation } \\
\hline \multicolumn{9}{|l|}{ Percentage HH Syrian } \\
\hline Percentage of HH Syr. & $\begin{array}{l}0.006 * \\
(0.002)\end{array}$ & $\begin{array}{l}0.003 \\
(0.002)\end{array}$ & & & $\begin{array}{l}0.012^{* * *} \\
(0.003)\end{array}$ & $\begin{array}{l}0.001 \\
(0.001)\end{array}$ & & \\
\hline \multicolumn{9}{|l|}{ Year (2010 omit.) } \\
\hline 2004 & $\begin{array}{l}-0.019 \\
(0.027)\end{array}$ & $\begin{array}{l}-0.004 \\
(0.029)\end{array}$ & $\begin{array}{l}-0.010 \\
(0.025)\end{array}$ & $\begin{array}{l}-0.002 \\
(0.002)\end{array}$ & $\begin{array}{l}-0.073 \\
(0.045)\end{array}$ & $\begin{array}{l}-0.023 \\
(0.023)\end{array}$ & $\begin{array}{l}-0.016 \\
(0.020)\end{array}$ & $\begin{array}{l}-0.013 \\
(0.012)\end{array}$ \\
\hline 2005 & $\begin{array}{l}-0.035 \\
(0.020)\end{array}$ & $\begin{array}{l}-0.010 \\
(0.024)\end{array}$ & $\begin{array}{l}-0.011 \\
(0.019)\end{array}$ & $\begin{array}{l}-0.002 \\
(0.002)\end{array}$ & $\begin{array}{l}-0.077 \\
(0.045)\end{array}$ & $\begin{array}{l}-0.023 \\
(0.019)\end{array}$ & $\begin{array}{l}-0.026 \\
(0.017)\end{array}$ & $\begin{array}{l}-0.009 \\
(0.008)\end{array}$ \\
\hline 2006 & $\begin{array}{l}-0.009 \\
(0.024)\end{array}$ & $\begin{array}{l}-0.005 \\
(0.025)\end{array}$ & $\begin{array}{l}-0.007 \\
(0.025)\end{array}$ & $\begin{array}{l}-0.002 \\
(0.002)\end{array}$ & $\begin{array}{l}-0.006 \\
(0.034)\end{array}$ & $\begin{array}{l}-0.013 \\
(0.017)\end{array}$ & $\begin{array}{l}-0.017 \\
(0.014)\end{array}$ & $\begin{array}{l}-0.007 \\
(0.007)\end{array}$ \\
\hline 2007 & $\begin{array}{l}-0.017 \\
(0.024)\end{array}$ & $\begin{array}{l}-0.010 \\
(0.023)\end{array}$ & $\begin{array}{l}-0.015 \\
(0.021)\end{array}$ & $\begin{array}{l}-0.003 \\
(0.002)\end{array}$ & $\begin{array}{l}0.003 \\
(0.030)\end{array}$ & $\begin{array}{l}0.002 \\
(0.015)\end{array}$ & $\begin{array}{l}-0.009 \\
(0.011)\end{array}$ & $\begin{array}{l}-0.005 \\
(0.005)\end{array}$ \\
\hline 2008 & $\begin{array}{l}0.001 \\
(0.021)\end{array}$ & $\begin{array}{l}0.012 \\
(0.019)\end{array}$ & $\begin{array}{l}0.003 \\
(0.016)\end{array}$ & $\begin{array}{l}0.001 \\
(0.001)\end{array}$ & $\begin{array}{l}-0.008 \\
(0.023)\end{array}$ & $\begin{array}{l}0.013 \\
(0.011)\end{array}$ & $\begin{array}{l}-0.003 \\
(0.009)\end{array}$ & $\begin{array}{l}-0.004 \\
(0.003)\end{array}$ \\
\hline 2009 & $\begin{array}{l}0.023 \\
(0.018)\end{array}$ & $\begin{array}{l}0.035 * \\
(0.015)\end{array}$ & $\begin{array}{l}0.023^{*} \\
(0.011)\end{array}$ & $\begin{array}{l}0.000 \\
(0.000)\end{array}$ & $\begin{array}{l}-0.007 \\
(0.018)\end{array}$ & $\begin{array}{l}0.009 \\
(0.010)\end{array}$ & $\begin{array}{l}0.004 \\
(0.005)\end{array}$ & $\begin{array}{l}-0.002 \\
(0.002)\end{array}$ \\
\hline 2011 & $\begin{array}{l}0.002 \\
(0.005)\end{array}$ & $\begin{array}{l}0.001 \\
(0.004)\end{array}$ & $\begin{array}{l}-0.001 \\
(0.004)\end{array}$ & $\begin{array}{l}-0.000 \\
(0.000)\end{array}$ & $\begin{array}{l}0.004 \\
(0.008)\end{array}$ & $\begin{array}{l}-0.004 \\
(0.003)\end{array}$ & $\begin{array}{l}-0.005^{*} \\
(0.003)\end{array}$ & $\begin{array}{l}0.001 \\
(0.002)\end{array}$ \\
\hline 2012 & $\begin{array}{l}0.014 \\
(0.012)\end{array}$ & $\begin{array}{l}0.015 \\
(0.012)\end{array}$ & $\begin{array}{l}-0.000 \\
(0.008)\end{array}$ & $\begin{array}{l}-0.002 \\
(0.002)\end{array}$ & $\begin{array}{l}0.008 \\
(0.018)\end{array}$ & $\begin{array}{l}-0.005 \\
(0.011)\end{array}$ & $\begin{array}{l}-0.004 \\
(0.007)\end{array}$ & $\begin{array}{l}0.002 \\
(0.003)\end{array}$ \\
\hline 2013 & $\begin{array}{l}0.039 * * \\
(0.014)\end{array}$ & $\begin{array}{l}0.038 * * \\
(0.013)\end{array}$ & $\begin{array}{l}0.016 \\
(0.011)\end{array}$ & $\begin{array}{l}-0.002 \\
(0.002)\end{array}$ & $\begin{array}{l}0.036 \\
(0.020)\end{array}$ & $\begin{array}{l}0.011 \\
(0.012)\end{array}$ & $\begin{array}{l}0.006 \\
(0.011)\end{array}$ & $\begin{array}{l}0.004 \\
(0.005)\end{array}$ \\
\hline 2014 & $\begin{array}{l}0.052^{* * *} \\
(0.015)\end{array}$ & $\begin{array}{l}0.049 * * * \\
(0.015)\end{array}$ & $\begin{array}{l}0.032 * \\
(0.013)\end{array}$ & $\begin{array}{l}-0.002 \\
(0.002)\end{array}$ & $\begin{array}{l}0.061 * * \\
(0.022)\end{array}$ & $\begin{array}{l}0.018 \\
(0.013)\end{array}$ & $\begin{array}{l}0.015 \\
(0.012)\end{array}$ & $\begin{array}{l}0.001 \\
(0.003)\end{array}$ \\
\hline 2015 & $\begin{array}{l}0.062^{* * * *} \\
(0.018)\end{array}$ & $\begin{array}{l}0.062^{* * *} \\
(0.017)\end{array}$ & $\begin{array}{l}0.037 * \\
(0.015)\end{array}$ & $\begin{array}{l}-0.002 \\
(0.002)\end{array}$ & $\begin{array}{l}0.060 * * \\
(0.022)\end{array}$ & $\begin{array}{l}0.013 \\
(0.013)\end{array}$ & $\begin{array}{l}0.006 \\
(0.012)\end{array}$ & $\begin{array}{l}0.003 \\
(0.004)\end{array}$ \\
\hline 2016 & $\begin{array}{l}0.044^{*} \\
(0.019)\end{array}$ & $\begin{array}{l}0.041^{*} \\
(0.019)\end{array}$ & $\begin{array}{l}0.028 \\
(0.017)\end{array}$ & $\begin{array}{l}-0.002 \\
(0.003)\end{array}$ & $\begin{array}{l}0.074^{*} \\
(0.029)\end{array}$ & $\begin{array}{l}0.021 \\
(0.020)\end{array}$ & $\begin{array}{l}0.014 \\
(0.017)\end{array}$ & $\begin{array}{l}0.004 \\
(0.006)\end{array}$ \\
\hline 2017 & $\begin{array}{l}0.023 \\
(0.023)\end{array}$ & $\begin{array}{l}0.017 \\
(0.023)\end{array}$ & $\begin{array}{l}0.004 \\
(0.021)\end{array}$ & $\begin{array}{l}-0.003 \\
(0.003)\end{array}$ & $\begin{array}{l}0.080 * \\
(0.031)\end{array}$ & $\begin{array}{l}0.016 \\
(0.021)\end{array}$ & $\begin{array}{l}0.011 \\
(0.018)\end{array}$ & $\begin{array}{l}0.006 \\
(0.007)\end{array}$ \\
\hline Int. year and \% HH Syr. & & & & & & & & \\
\hline Int. 2004 and \% HH Syr. & $\begin{array}{l}0.002 \\
(0.002)\end{array}$ & $\begin{array}{l}0.002 \\
(0.002)\end{array}$ & $\begin{array}{l}0.003 * \\
(0.001)\end{array}$ & $\begin{array}{l}0.001 \\
(0.001)\end{array}$ & $\begin{array}{l}-0.001 \\
(0.003)\end{array}$ & $\begin{array}{l}0.002 \\
(0.001)\end{array}$ & $\begin{array}{l}0.002 \\
(0.001)\end{array}$ & $\begin{array}{l}0.000 \\
(0.000)\end{array}$ \\
\hline Int. 2005 and \% HH Syr. & $0.003^{*}$ & 0.002 & $0.002 *$ & 0.001 & 0.002 & $0.003^{*}$ & $0.003 * *$ & 0.000 \\
\hline
\end{tabular}




\begin{tabular}{|c|c|c|c|c|c|c|c|c|}
\hline & $(1)$ & $(2)$ & (3) & (4) & (5) & $(6)$ & $(7)$ & $(8)$ \\
\hline & \multicolumn{4}{|c|}{ Formal } & \multicolumn{4}{|c|}{ Managerial/Professional Occupation } \\
\hline \multirow{3}{*}{ Int. 2006 and \% HH Syr. } & $(0.001)$ & $(0.001)$ & $\overline{(0.001)}$ & $(0.001)$ & $(0.003)$ & (0.001) & $\bar{c}(0.001)$ & $\overline{(0.000)}$ \\
\hline & 0.002 & 0.002 & 0.002 & 0.001 & -0.003 & 0.001 & 0.002 & 0.000 \\
\hline & $(0.001)$ & $(0.001)$ & $(0.001)$ & $(0.000)$ & $(0.002)$ & $(0.001)$ & $(0.001)$ & $(0.000)$ \\
\hline \multirow[t]{2}{*}{ Int. 2007 and \% HH Syr. } & 0.002 & 0.002 & 0.002 & 0.000 & -0.002 & 0.001 & 0.001 & 0.000 \\
\hline & $(0.001)$ & $(0.001)$ & $(0.001)$ & $(0.000)$ & $(0.002)$ & $(0.001)$ & $(0.001)$ & $(0.000)$ \\
\hline \multirow[t]{2}{*}{ Int. 2008 and \% HH Syr. } & 0.001 & 0.000 & 0.000 & 0.000 & -0.001 & -0.001 & 0.000 & 0.000 \\
\hline & $(0.001)$ & $(0.001)$ & $(0.001)$ & $(0.000)$ & $(0.002)$ & $(0.001)$ & $(0.001)$ & $(0.000)$ \\
\hline \multirow[t]{2}{*}{ Int. 2009 and \% HH Syr. } & -0.001 & -0.001 & -0.001 & 0.000 & -0.001 & -0.001 & -0.000 & 0.000 \\
\hline & $(0.001)$ & $(0.001)$ & $(0.001)$ & $(0.000)$ & $(0.001)$ & $(0.001)$ & $(0.000)$ & $(0.000)$ \\
\hline \multirow[t]{2}{*}{ Int. 2011 and \% HH Syr. } & -0.000 & 0.000 & 0.000 & -0.000 & -0.000 & 0.000 & 0.000 & 0.000 \\
\hline & $(0.000)$ & $(0.000)$ & $(0.000)$ & $(0.000)$ & $(0.000)$ & $(0.000)$ & $(0.000)$ & $(0.000)$ \\
\hline \multirow[t]{2}{*}{ Int. 2012 and \% HH Syr. } & -0.001 & -0.001 & 0.000 & 0.000 & -0.001 & -0.001 & -0.000 & 0.000 \\
\hline & $(0.001)$ & $(0.001)$ & $(0.001)$ & $(0.000)$ & $(0.001)$ & $(0.001)$ & $(0.000)$ & $(0.000)$ \\
\hline \multirow[t]{2}{*}{ Int. 2013 and \% HH Syr. } & $-0.004 *$ & $-0.003^{*}$ & -0.001 & 0.000 & -0.003 & $-0.002 *$ & -0.001 & 0.000 \\
\hline & $(0.002)$ & $(0.001)$ & $(0.001)$ & $(0.000)$ & $(0.002)$ & $(0.001)$ & $(0.001)$ & $(0.000)$ \\
\hline \multirow[t]{2}{*}{ Int. 2014 and \% HH Syr. } & $-0.004^{*}$ & $-0.003^{*}$ & -0.001 & 0.000 & $-0.005^{* *}$ & $-0.003 * *$ & $-0.002 * *$ & -0.000 \\
\hline & $(0.002)$ & $(0.001)$ & $(0.001)$ & $(0.000)$ & $(0.002)$ & $(0.001)$ & $(0.001)$ & $(0.000)$ \\
\hline \multirow[t]{2}{*}{ Int. 2015 and \% HH Syr. } & $-0.005^{* *}$ & $-0.004^{* *}$ & -0.001 & -0.000 & $-0.005 * *$ & $-0.003^{* *}$ & $-0.002 * *$ & -0.000 \\
\hline & $(0.001)$ & $(0.001)$ & $(0.001)$ & $(0.000)$ & $(0.002)$ & $(0.001)$ & $(0.001)$ & $(0.000)$ \\
\hline \multirow[t]{2}{*}{ Int. 2016 and \% HH Syr. } & $-0.005 * * *$ & $-0.004 * *$ & -0.001 & -0.000 & $-0.006 * * *$ & $-0.004 * * *$ & $-0.003 * * *$ & -0.000 \\
\hline & $(0.001)$ & $(0.001)$ & $(0.001)$ & $(0.000)$ & $(0.002)$ & $(0.001)$ & $(0.001)$ & $(0.000)$ \\
\hline \multirow[t]{2}{*}{ Int. 2017 and \% HH Syr. } & $-0.003 *$ & -0.002 & -0.000 & -0.000 & $-0.006 * *$ & $-0.004 * *$ & $-0.003^{* *}$ & -0.000 \\
\hline & $(0.002)$ & $(0.002)$ & $(0.001)$ & $(0.000)$ & $(0.002)$ & $(0.001)$ & $(0.001)$ & $(0.000)$ \\
\hline Controls & & $\mathrm{X}$ & $\mathrm{X}$ & $\mathrm{X}$ & & $\mathrm{X}$ & $\mathrm{X}$ & $\mathrm{X}$ \\
\hline Locality FE & & & $\mathrm{X}$ & & & & $X$ & \\
\hline Individual FE & & & & $\mathrm{X}$ & & & & $\mathrm{X}$ \\
\hline N (Person-Year Obs.) & 9241 & 9146 & 9146 & 9241 & 9150 & 9059 & 9059 & 9150 \\
\hline R-sq. & 0.010 & 0.173 & 0.434 & 0.012 & 0.025 & 0.690 & 0.769 & 0.010 \\
\hline
\end{tabular}

Source: Authors’ calculations based on JLMPS 2016

Notes: ${ }^{*} \mathrm{p}<0.05 ;{ }^{* *} \mathrm{p}<0.01 ;{ }^{* * *} \mathrm{p}<0.001$

Controls include education level, mother's education level, father's education level, father's employment status, age, and age squared Standard errors (in parentheses) clustered at the locality level 
Table 6. Job sector (linear probability model), employed women, retrospective data 2004-2017

\begin{tabular}{|c|c|c|c|c|c|c|c|c|c|c|c|c|}
\hline & $(1)$ & $(2)$ & $(3)$ & (4) & (5) & $(6)$ & $(7)$ & $(8)$ & (9) & $(10)$ & $(11)$ & $(12)$ \\
\hline & \multicolumn{4}{|c|}{ Open Sector } & \multicolumn{4}{|c|}{ Health and Human Services } & \multicolumn{4}{|c|}{ Private Sector } \\
\hline \multicolumn{13}{|l|}{ Percentage HH Syrian } \\
\hline Percentage of HH Syr. & $\begin{array}{l}-0.003 \\
(0.002)\end{array}$ & $\begin{array}{l}0.001 \\
(0.002)\end{array}$ & & & $\begin{array}{l}-0.001 \\
(0.003)\end{array}$ & $\begin{array}{l}-0.007 * \\
(0.003)\end{array}$ & & & $\begin{array}{l}-0.003 \\
(0.005)\end{array}$ & $\begin{array}{l}0.001 \\
(0.004)\end{array}$ & & \\
\hline \multicolumn{13}{|l|}{ Year (2010 omit.) } \\
\hline 2004 & $\begin{array}{l}0.077 * \\
(0.038)\end{array}$ & $\begin{array}{l}0.056 \\
(0.033)\end{array}$ & $\begin{array}{l}0.035 \\
(0.032)\end{array}$ & $\begin{array}{l}0.029 \\
(0.031)\end{array}$ & $\begin{array}{l}-0.110 * \\
(0.046)\end{array}$ & $\begin{array}{l}-0.073 \\
(0.042)\end{array}$ & $\begin{array}{l}-0.027 \\
(0.040)\end{array}$ & $\begin{array}{l}0.006 \\
(0.010)\end{array}$ & $\begin{array}{l}0.000 \\
(0.054)\end{array}$ & $\begin{array}{l}-0.007 \\
(0.048)\end{array}$ & $\begin{array}{l}-0.025 \\
(0.047)\end{array}$ & $\begin{array}{l}0.005 \\
(0.006)\end{array}$ \\
\hline 2005 & $\begin{array}{l}0.068 * \\
(0.031)\end{array}$ & $\begin{array}{l}0.048 \\
(0.026)\end{array}$ & $\begin{array}{l}0.025 \\
(0.025)\end{array}$ & $\begin{array}{l}0.027 \\
(0.027)\end{array}$ & $\begin{array}{l}-0.098 * \\
(0.045)\end{array}$ & $\begin{array}{l}-0.057 \\
(0.041)\end{array}$ & $\begin{array}{l}-0.019 \\
(0.038)\end{array}$ & $\begin{array}{l}0.005 \\
(0.010)\end{array}$ & $\begin{array}{l}0.015 \\
(0.048)\end{array}$ & $\begin{array}{l}-0.005 \\
(0.042)\end{array}$ & $\begin{array}{l}-0.034 \\
(0.041)\end{array}$ & $\begin{array}{l}0.006 \\
(0.005)\end{array}$ \\
\hline 2006 & $\begin{array}{l}0.027 \\
(0.030)\end{array}$ & $\begin{array}{l}0.031 \\
(0.028)\end{array}$ & $\begin{array}{l}0.016 \\
(0.026)\end{array}$ & $\begin{array}{l}0.023 \\
(0.023)\end{array}$ & $\begin{array}{l}-0.021 \\
(0.038)\end{array}$ & $\begin{array}{l}-0.017 \\
(0.036)\end{array}$ & $\begin{array}{l}-0.002 \\
(0.033)\end{array}$ & $\begin{array}{l}0.003 \\
(0.007)\end{array}$ & $\begin{array}{l}-0.031 \\
(0.044)\end{array}$ & $\begin{array}{l}-0.032 \\
(0.038)\end{array}$ & $\begin{array}{l}-0.050 \\
(0.037)\end{array}$ & $\begin{array}{l}0.005 \\
(0.004)\end{array}$ \\
\hline 2007 & $\begin{array}{l}0.013 \\
(0.021)\end{array}$ & $\begin{array}{l}0.014 \\
(0.018)\end{array}$ & $\begin{array}{l}0.005 \\
(0.018)\end{array}$ & $\begin{array}{l}0.009 \\
(0.010)\end{array}$ & $\begin{array}{l}0.011 \\
(0.033)\end{array}$ & $\begin{array}{l}0.018 \\
(0.028)\end{array}$ & $\begin{array}{l}0.018 \\
(0.024)\end{array}$ & $\begin{array}{l}0.004 \\
(0.005)\end{array}$ & $\begin{array}{l}-0.037 \\
(0.036)\end{array}$ & $\begin{array}{l}-0.044 \\
(0.032)\end{array}$ & $\begin{array}{l}-0.048 \\
(0.030)\end{array}$ & $\begin{array}{l}0.004 \\
(0.003)\end{array}$ \\
\hline 2008 & $\begin{array}{l}0.004 \\
(0.019)\end{array}$ & $\begin{array}{l}-0.001 \\
(0.016)\end{array}$ & $\begin{array}{l}-0.004 \\
(0.015)\end{array}$ & $\begin{array}{l}0.005 \\
(0.006)\end{array}$ & $\begin{array}{l}0.002 \\
(0.026)\end{array}$ & $\begin{array}{l}0.015 \\
(0.024)\end{array}$ & $\begin{array}{l}0.012 \\
(0.020)\end{array}$ & $\begin{array}{l}0.003 \\
(0.004)\end{array}$ & $\begin{array}{l}-0.050 \\
(0.028)\end{array}$ & $\begin{array}{l}-0.058 * \\
(0.024)\end{array}$ & $\begin{array}{l}-0.050 * \\
(0.019)\end{array}$ & $\begin{array}{l}0.002 \\
(0.002)\end{array}$ \\
\hline 2009 & $\begin{array}{l}0.002 \\
(0.014)\end{array}$ & $\begin{array}{l}-0.005 \\
(0.013)\end{array}$ & $\begin{array}{l}-0.005 \\
(0.013)\end{array}$ & $\begin{array}{l}0.002 \\
(0.003)\end{array}$ & $\begin{array}{l}0.004 \\
(0.021)\end{array}$ & $\begin{array}{l}0.016 \\
(0.020)\end{array}$ & $\begin{array}{l}0.017 \\
(0.016)\end{array}$ & $\begin{array}{l}0.001 \\
(0.002)\end{array}$ & $\begin{array}{l}-0.041 \\
(0.024)\end{array}$ & $\begin{array}{l}-0.050 * \\
(0.022)\end{array}$ & $\begin{array}{l}-0.042 * \\
(0.018)\end{array}$ & $\begin{array}{l}0.001 \\
(0.001)\end{array}$ \\
\hline 2011 & $\begin{array}{l}0.003 \\
(0.005)\end{array}$ & $\begin{array}{l}0.007 \\
(0.004)\end{array}$ & $\begin{array}{l}0.009 * \\
(0.004)\end{array}$ & $\begin{array}{l}-0.003 \\
(0.003)\end{array}$ & $\begin{array}{l}0.001 \\
(0.010)\end{array}$ & $\begin{array}{l}-0.003 \\
(0.009)\end{array}$ & $\begin{array}{l}-0.012 \\
(0.009)\end{array}$ & $\begin{array}{l}0.003 \\
(0.005)\end{array}$ & $\begin{array}{l}0.008 \\
(0.010)\end{array}$ & $\begin{array}{l}0.010 \\
(0.011)\end{array}$ & $\begin{array}{l}0.019 \\
(0.010)\end{array}$ & $\begin{array}{l}-0.000 \\
(0.001)\end{array}$ \\
\hline 2012 & $\begin{array}{l}0.001 \\
(0.012)\end{array}$ & $\begin{array}{l}0.010 \\
(0.010)\end{array}$ & $\begin{array}{l}0.013 \\
(0.007)\end{array}$ & $\begin{array}{l}-0.007 \\
(0.006)\end{array}$ & $\begin{array}{l}-0.013 \\
(0.020)\end{array}$ & $\begin{array}{l}-0.018 \\
(0.015)\end{array}$ & $\begin{array}{l}-0.026 * \\
(0.012)\end{array}$ & $\begin{array}{l}-0.000 \\
(0.004)\end{array}$ & $\begin{array}{l}0.023 \\
(0.018)\end{array}$ & $\begin{array}{l}0.028 \\
(0.019)\end{array}$ & $\begin{array}{l}0.044^{* *} \\
(0.014)\end{array}$ & $\begin{array}{l}-0.001 \\
(0.002)\end{array}$ \\
\hline 2013 & $\begin{array}{l}-0.009 \\
(0.014)\end{array}$ & $\begin{array}{l}0.004 \\
(0.012)\end{array}$ & $\begin{array}{l}0.010 \\
(0.011)\end{array}$ & $\begin{array}{l}-0.007 \\
(0.009)\end{array}$ & $\begin{array}{l}0.007 \\
(0.024)\end{array}$ & $\begin{array}{l}-0.011 \\
(0.019)\end{array}$ & $\begin{array}{l}-0.033^{*} \\
(0.017)\end{array}$ & $\begin{array}{l}-0.002 \\
(0.005)\end{array}$ & $\begin{array}{l}0.021 \\
(0.023)\end{array}$ & $\begin{array}{l}0.034 \\
(0.025)\end{array}$ & $\begin{array}{l}0.059 * * \\
(0.021)\end{array}$ & $\begin{array}{l}0.001 \\
(0.003)\end{array}$ \\
\hline 2014 & $\begin{array}{l}-0.019 \\
(0.016)\end{array}$ & $\begin{array}{l}0.004 \\
(0.013)\end{array}$ & $\begin{array}{l}0.013 \\
(0.011)\end{array}$ & $\begin{array}{l}-0.008 \\
(0.013)\end{array}$ & $\begin{array}{l}0.012 \\
(0.028)\end{array}$ & $\begin{array}{l}-0.016 \\
(0.023)\end{array}$ & $\begin{array}{l}-0.044 \\
(0.023)\end{array}$ & $\begin{array}{l}-0.004 \\
(0.008)\end{array}$ & $\begin{array}{l}0.032 \\
(0.024)\end{array}$ & $\begin{array}{l}0.049 * \\
(0.024)\end{array}$ & $\begin{array}{l}0.077 * * * \\
(0.022)\end{array}$ & $\begin{array}{l}-0.001 \\
(0.003)\end{array}$ \\
\hline 2015 & $\begin{array}{l}-0.008 \\
(0.023)\end{array}$ & $\begin{array}{l}0.020 \\
(0.020)\end{array}$ & $\begin{array}{l}0.031 \\
(0.018)\end{array}$ & $\begin{array}{l}-0.011 \\
(0.016)\end{array}$ & $\begin{array}{l}0.018 \\
(0.033)\end{array}$ & $\begin{array}{l}-0.012 \\
(0.024)\end{array}$ & $\begin{array}{l}-0.045^{*} \\
(0.022)\end{array}$ & $\begin{array}{l}-0.005 \\
(0.009)\end{array}$ & $\begin{array}{l}0.055 \\
(0.032)\end{array}$ & $\begin{array}{l}0.076 * * \\
(0.029)\end{array}$ & $\begin{array}{l}0.113^{* * *} \\
(0.028)\end{array}$ & $\begin{array}{l}-0.002 \\
(0.004)\end{array}$ \\
\hline 2016 & $\begin{array}{l}0.002 \\
(0.025)\end{array}$ & $\begin{array}{l}0.035 \\
(0.023)\end{array}$ & $\begin{array}{l}0.029 \\
(0.020)\end{array}$ & $\begin{array}{l}-0.013 \\
(0.019)\end{array}$ & $\begin{array}{l}-0.012 \\
(0.039)\end{array}$ & $\begin{array}{l}-0.047 \\
(0.031)\end{array}$ & $\begin{array}{l}-0.068 * \\
(0.028)\end{array}$ & $\begin{array}{l}-0.006 \\
(0.011)\end{array}$ & $\begin{array}{l}0.043 \\
(0.033)\end{array}$ & $\begin{array}{l}0.064^{*} \\
(0.031)\end{array}$ & $\begin{array}{l}0.113^{* * *} \\
(0.030)\end{array}$ & $\begin{array}{l}-0.006 \\
(0.005)\end{array}$ \\
\hline 2017 & $\begin{array}{l}0.001 \\
(0.026)\end{array}$ & $\begin{array}{l}0.041 \\
(0.024)\end{array}$ & $\begin{array}{l}0.033 \\
(0.023)\end{array}$ & $\begin{array}{l}-0.015 \\
(0.021)\end{array}$ & $\begin{array}{l}-0.001 \\
(0.041)\end{array}$ & $\begin{array}{l}-0.050 \\
(0.032)\end{array}$ & $\begin{array}{l}-0.076 * * \\
(0.029)\end{array}$ & $\begin{array}{l}-0.007 \\
(0.012)\end{array}$ & $\begin{array}{l}0.049 \\
(0.038)\end{array}$ & $\begin{array}{l}0.085 * \\
(0.036)\end{array}$ & $\begin{array}{l}0.132 * * * \\
(0.034)\end{array}$ & $\begin{array}{l}-0.007 \\
(0.006)\end{array}$ \\
\hline \multicolumn{13}{|l|}{ Int. year and \% HH Syr. } \\
\hline Int. 2004 and \% HH Syr. & $\begin{array}{l}-0.003 \\
(0.002)\end{array}$ & $\begin{array}{l}-0.004 \\
(0.002)\end{array}$ & $\begin{array}{l}-0.002 \\
(0.002)\end{array}$ & $\begin{array}{l}-0.001 \\
(0.001)\end{array}$ & $\begin{array}{l}0.007^{*} \\
(0.003)\end{array}$ & $\begin{array}{l}0.007 * \\
(0.003)\end{array}$ & $\begin{array}{l}0.004 \\
(0.003)\end{array}$ & $\begin{array}{l}-0.000 \\
(0.000)\end{array}$ & $\begin{array}{l}-0.002 \\
(0.004)\end{array}$ & $\begin{array}{l}-0.002 \\
(0.004)\end{array}$ & $\begin{array}{l}-0.002 \\
(0.003)\end{array}$ & $\begin{array}{l}-0.000 \\
(0.000)\end{array}$ \\
\hline Int. 2005 and \% HH Syr. & -0.003 & $-0.004^{*}$ & -0.002 & -0.001 & $0.009 *$ & $0.008 * *$ & 0.005 & -0.000 & -0.002 & -0.001 & -0.000 & -0.000 \\
\hline
\end{tabular}




\begin{tabular}{|c|c|c|c|c|c|c|c|c|c|c|c|c|}
\hline & $(1)$ & $(2)$ & $(3)$ & $(4)$ & (5) & (6) & $(7)$ & $(8)$ & (9) & $(10)$ & $(11)$ & $(12)$ \\
\hline & \multicolumn{4}{|c|}{ Open Sector } & \multicolumn{4}{|c|}{ Health and Human Services } & \multicolumn{4}{|c|}{ Private Sector } \\
\hline & $(0.002)$ & $(0.002)$ & $(0.002)$ & $(0.001)$ & $(0.004)$ & (0.003) & $(0.003)$ & $(0.000)$ & $(0.003)$ & $(0.003)$ & $(0.002)$ & $(0.000)$ \\
\hline Int. 2006 and \% HH Syr. & $\begin{array}{l}-0.002 \\
(0.002)\end{array}$ & $\begin{array}{l}-0.003 \\
(0.002)\end{array}$ & $\begin{array}{l}-0.001 \\
(0.002)\end{array}$ & $\begin{array}{l}-0.001 \\
(0.001)\end{array}$ & $\begin{array}{l}0.002 \\
(0.003)\end{array}$ & $\begin{array}{l}0.004 \\
(0.003)\end{array}$ & $\begin{array}{l}0.002 \\
(0.003)\end{array}$ & $\begin{array}{l}0.000 \\
(0.000)\end{array}$ & $\begin{array}{l}-0.001 \\
(0.003)\end{array}$ & $\begin{array}{l}-0.001 \\
(0.003)\end{array}$ & $\begin{array}{l}0.000 \\
(0.002)\end{array}$ & $\begin{array}{l}-0.000 \\
(0.000)\end{array}$ \\
\hline Int. 2007 and \% HH Syr. & $\begin{array}{l}-0.001 \\
(0.001)\end{array}$ & $\begin{array}{l}-0.001 \\
(0.001)\end{array}$ & $\begin{array}{l}-0.000 \\
(0.001)\end{array}$ & $\begin{array}{l}-0.000 \\
(0.000)\end{array}$ & $\begin{array}{l}-0.000 \\
(0.002)\end{array}$ & $\begin{array}{l}-0.000 \\
(0.002)\end{array}$ & $\begin{array}{l}-0.001 \\
(0.002)\end{array}$ & $\begin{array}{l}-0.000 \\
(0.000)\end{array}$ & $\begin{array}{l}-0.000 \\
(0.003)\end{array}$ & $\begin{array}{l}0.001 \\
(0.003)\end{array}$ & $\begin{array}{l}0.001 \\
(0.002)\end{array}$ & $\begin{array}{l}-0.000 \\
(0.000)\end{array}$ \\
\hline Int. 2008 and \% HH Syr. & $\begin{array}{l}0.000 \\
(0.001)\end{array}$ & $\begin{array}{l}0.000 \\
(0.001)\end{array}$ & $\begin{array}{l}0.001 \\
(0.001)\end{array}$ & $\begin{array}{l}-0.000 \\
(0.000)\end{array}$ & $\begin{array}{l}-0.000 \\
(0.002)\end{array}$ & $\begin{array}{l}-0.001 \\
(0.002)\end{array}$ & $\begin{array}{l}-0.001 \\
(0.002)\end{array}$ & $\begin{array}{l}-0.000 \\
(0.000)\end{array}$ & $\begin{array}{l}0.001 \\
(0.002)\end{array}$ & $\begin{array}{l}0.003 \\
(0.003)\end{array}$ & $\begin{array}{l}0.003 \\
(0.002)\end{array}$ & $\begin{array}{l}-0.000 \\
(0.000)\end{array}$ \\
\hline Int. 2009 and \% HH Syr. & $\begin{array}{l}-0.000 \\
(0.001)\end{array}$ & $\begin{array}{l}-0.000 \\
(0.001)\end{array}$ & $\begin{array}{l}0.000 \\
(0.001)\end{array}$ & $\begin{array}{l}0.000 \\
(0.000)\end{array}$ & $\begin{array}{l}-0.001 \\
(0.002)\end{array}$ & $\begin{array}{l}-0.002 \\
(0.002)\end{array}$ & $\begin{array}{l}-0.002 \\
(0.002)\end{array}$ & $\begin{array}{l}-0.000 \\
(0.000)\end{array}$ & $\begin{array}{l}0.001 \\
(0.002)\end{array}$ & $\begin{array}{l}0.003 \\
(0.002)\end{array}$ & $\begin{array}{l}0.002 \\
(0.002)\end{array}$ & $\begin{array}{l}-0.000 \\
(0.000)\end{array}$ \\
\hline Int. 2011 and \% HH Syr. & $\begin{array}{l}0.000 \\
(0.000)\end{array}$ & $\begin{array}{l}0.000 \\
(0.000)\end{array}$ & $\begin{array}{l}0.000 \\
(0.000)\end{array}$ & $\begin{array}{l}0.000 \\
(0.000)\end{array}$ & $\begin{array}{l}0.000 \\
(0.001)\end{array}$ & $\begin{array}{l}0.000 \\
(0.001)\end{array}$ & $\begin{array}{l}0.001 \\
(0.000)\end{array}$ & $\begin{array}{l}-0.000 \\
(0.000)\end{array}$ & $\begin{array}{l}0.000 \\
(0.001)\end{array}$ & $\begin{array}{l}0.000 \\
(0.001)\end{array}$ & $\begin{array}{l}0.000 \\
(0.001)\end{array}$ & $\begin{array}{l}-0.000 \\
(0.000)\end{array}$ \\
\hline Int. 2012 and \% HH Syr. & $\begin{array}{l}0.001 \\
(0.001)\end{array}$ & $\begin{array}{l}0.000 \\
(0.001)\end{array}$ & $\begin{array}{l}-0.000 \\
(0.000)\end{array}$ & $\begin{array}{l}0.000 \\
(0.000)\end{array}$ & $\begin{array}{l}0.002 \\
(0.001)\end{array}$ & $\begin{array}{l}0.001 \\
(0.001)\end{array}$ & $\begin{array}{l}0.002 * \\
(0.001)\end{array}$ & $\begin{array}{l}0.000 \\
(0.000)\end{array}$ & $\begin{array}{l}0.000 \\
(0.001)\end{array}$ & $\begin{array}{l}0.000 \\
(0.001)\end{array}$ & $\begin{array}{l}-0.001 \\
(0.001)\end{array}$ & $\begin{array}{l}0.000 \\
(0.000)\end{array}$ \\
\hline Int. 2013 and \% HH Syr. & $\begin{array}{l}0.001 \\
(0.001)\end{array}$ & $\begin{array}{l}0.001 \\
(0.001)\end{array}$ & $\begin{array}{l}-0.000 \\
(0.001)\end{array}$ & $\begin{array}{l}-0.000 \\
(0.000)\end{array}$ & $\begin{array}{l}0.000 \\
(0.002)\end{array}$ & $\begin{array}{l}0.001 \\
(0.002)\end{array}$ & $\begin{array}{l}0.002 \\
(0.001)\end{array}$ & $\begin{array}{l}0.000 \\
(0.000)\end{array}$ & $\begin{array}{l}0.001 \\
(0.002)\end{array}$ & $\begin{array}{l}0.001 \\
(0.002)\end{array}$ & $\begin{array}{l}-0.001 \\
(0.002)\end{array}$ & $\begin{array}{l}-0.000 \\
(0.000)\end{array}$ \\
\hline Int. 2014 and \% HH Syr. & $\begin{array}{l}0.001 \\
(0.001)\end{array}$ & $\begin{array}{l}0.001 \\
(0.001)\end{array}$ & $\begin{array}{l}-0.001 \\
(0.001)\end{array}$ & $\begin{array}{l}-0.000 \\
(0.000)\end{array}$ & $\begin{array}{l}-0.000 \\
(0.002)\end{array}$ & $\begin{array}{l}0.001 \\
(0.002)\end{array}$ & $\begin{array}{l}0.002 \\
(0.002)\end{array}$ & $\begin{array}{l}0.000 \\
(0.000)\end{array}$ & $\begin{array}{l}0.002 \\
(0.002)\end{array}$ & $\begin{array}{l}0.001 \\
(0.002)\end{array}$ & $\begin{array}{l}-0.000 \\
(0.002)\end{array}$ & $\begin{array}{l}-0.000 \\
(0.000)\end{array}$ \\
\hline Int. 2015 and \% HH Syr. & $\begin{array}{l}0.001 \\
(0.002)\end{array}$ & $\begin{array}{l}-0.000 \\
(0.001)\end{array}$ & $\begin{array}{l}-0.001 \\
(0.001)\end{array}$ & $\begin{array}{l}-0.000 \\
(0.000)\end{array}$ & $\begin{array}{l}-0.002 \\
(0.003)\end{array}$ & $\begin{array}{l}-0.000 \\
(0.002)\end{array}$ & $\begin{array}{l}0.001 \\
(0.002)\end{array}$ & $\begin{array}{l}0.000 \\
(0.000)\end{array}$ & $\begin{array}{l}0.002 \\
(0.003)\end{array}$ & $\begin{array}{l}0.001 \\
(0.002)\end{array}$ & $\begin{array}{l}-0.001 \\
(0.002)\end{array}$ & $\begin{array}{l}-0.000 \\
(0.000)\end{array}$ \\
\hline Int. 2016 and \% HH Syr. & $\begin{array}{l}0.001 \\
(0.002)\end{array}$ & $\begin{array}{l}0.000 \\
(0.002)\end{array}$ & $\begin{array}{l}-0.001 \\
(0.001)\end{array}$ & $\begin{array}{l}-0.000 \\
(0.000)\end{array}$ & $\begin{array}{l}-0.002 \\
(0.003)\end{array}$ & $\begin{array}{l}-0.000 \\
(0.002)\end{array}$ & $\begin{array}{l}0.001 \\
(0.002)\end{array}$ & $\begin{array}{l}0.000 \\
(0.000)\end{array}$ & $\begin{array}{l}0.004 \\
(0.003)\end{array}$ & $\begin{array}{l}0.003 \\
(0.002)\end{array}$ & $\begin{array}{l}0.001 \\
(0.003)\end{array}$ & $\begin{array}{l}0.000 \\
(0.000)\end{array}$ \\
\hline Int. 2017 and \% HH Syr. & $\begin{array}{l}0.001 \\
(0.002)\end{array}$ & $\begin{array}{l}-0.000 \\
(0.002)\end{array}$ & $\begin{array}{l}-0.000 \\
(0.001)\end{array}$ & $\begin{array}{l}-0.000 \\
(0.000)\end{array}$ & $\begin{array}{l}-0.002 \\
(0.003)\end{array}$ & $\begin{array}{l}-0.000 \\
(0.003)\end{array}$ & $\begin{array}{l}0.001 \\
(0.002) \\
\end{array}$ & $\begin{array}{l}0.000 \\
(0.000)\end{array}$ & $\begin{array}{l}0.004 \\
(0.004)\end{array}$ & $\begin{array}{l}0.002 \\
(0.003)\end{array}$ & $\begin{array}{l}0.000 \\
(0.003)\end{array}$ & $\begin{array}{l}0.000 \\
(0.000)\end{array}$ \\
\hline Controls & & $\mathrm{X}$ & $\mathrm{X}$ & $\mathrm{X}$ & & $\mathrm{X}$ & $\mathrm{X}$ & $\mathrm{X}$ & & $\mathrm{X}$ & $\mathrm{X}$ & $\mathrm{X}$ \\
\hline Locality FE & & & $\mathrm{X}$ & & & & $X$ & & & & $\mathrm{X}$ & \\
\hline Individual FE & & & & $\mathrm{X}$ & & & & $\mathrm{X}$ & & & & $\mathrm{X}$ \\
\hline N (Person-Year Obs.) & 9155 & 9064 & 9064 & 9155 & 9155 & 9064 & 9064 & 9155 & 9241 & 9146 & 9146 & 9241 \\
\hline R-sq. & 0.005 & 0.195 & 0.399 & 0.010 & 0.002 & 0.199 & 0.424 & 0.005 & 0.010 & 0.193 & 0.546 & 0.003 \\
\hline
\end{tabular}

Source: Authors’ calculations based on JLMPS 2016

Notes: ${ }^{*} \mathrm{p}<0.05 ;{ }^{* *} \mathrm{p}<0.01 ;{ }^{* * *} \mathrm{p}<0.001$

Controls include education level, mother's education level, father's education level, father's employment status, age, and age squared Standard errors (in parentheses) clustered at the locality level 
Table 7. Labor market outcomes (fixed effects linear probability and OLS models), women, panel data

\begin{tabular}{|c|c|c|c|c|c|c|c|c|c|c|}
\hline & Unemployed & Employed & Formal & $\begin{array}{l}\text { Ln (hourly } \\
\text { wage) }\end{array}$ & $\begin{array}{l}\text { Hours per } \\
\text { week }\end{array}$ & $\begin{array}{l}\text { Ln (monthly } \\
\text { wage) }\end{array}$ & $\frac{\text { Managerial/ }}{\frac{\text { Professional }}{\text { Occupation }}}$ & Open sector & $\frac{\text { Health and }}{\text { Human Serv. }}$ & $\frac{\text { Private }}{\text { sector }}$ \\
\hline \multicolumn{11}{|l|}{ Year (2010 omit.) } \\
\hline 2016 & $\begin{array}{l}0.038^{*} \\
(0.019)\end{array}$ & $\begin{array}{l}-0.008 \\
(0.028)\end{array}$ & $\begin{array}{l}-0.344 \\
(0.192)\end{array}$ & $\begin{array}{l}0.117 \\
(0.780)\end{array}$ & $\begin{array}{l}15.274 * \\
(7.580)\end{array}$ & $\begin{array}{l}1.401^{*} \\
(0.708)\end{array}$ & $\begin{array}{l}-0.076 \\
(0.184)\end{array}$ & $\begin{array}{l}0.182 \\
(0.175)\end{array}$ & $\begin{array}{l}0.215 \\
(0.130)\end{array}$ & $\begin{array}{l}0.223 \\
(0.166)\end{array}$ \\
\hline \multicolumn{11}{|l|}{$\begin{array}{l}\text { Int. year and \% HH } \\
\text { Syrian } \\
\text { Int. } 2016 \text { and \% HH }\end{array}$} \\
\hline Syr. & $\begin{array}{l}-0.001 \\
(0.001) \\
\end{array}$ & $\begin{array}{l}0.000 \\
(0.001)\end{array}$ & $\begin{array}{l}0.004^{*} \\
(0.002)\end{array}$ & $\begin{array}{l}0.010 \\
(0.016) \\
\end{array}$ & $\begin{array}{l}-0.138 \\
(0.143) \\
\end{array}$ & $\begin{array}{l}0.000 \\
(0.006) \\
\end{array}$ & $\begin{array}{l}0.002 \\
(0.002) \\
\end{array}$ & $\begin{array}{l}-0.001 \\
(0.002) \\
\end{array}$ & $\begin{array}{l}-0.000 \\
(0.003) \\
\end{array}$ & $\begin{array}{l}-0.004 \\
(0.004)\end{array}$ \\
\hline $\mathbf{N}$ & 7411 & 7412 & 1071 & 979 & 1056 & 994 & 1193 & 1194 & 1194 & 1201 \\
\hline
\end{tabular}

Source: Authors’ calculations based on JLMPS 2010 - JLMPS 2016 panel

Notes: ${ }^{*} \mathrm{p}<0.05 ;{ }^{* *} \mathrm{p}<0.01 ;{ }^{* * *} \mathrm{p}<0.001$

Controlling for age and age squared in year

Standard errors (in parentheses) clustered at the locality level 


\section{Appendix D: Cross-sectional model results}

In this appendix, we present the results treating the JLMPS 2010 and JLMPS 2016 waves as two cross sections. Essentially, pooled cross-sectional difference-in-difference models are estimated. We present the models across three specifications. The first has no controls, the second has controls, and the third adds sub-district (geographic) fixed effects (our preferred specification). Since we lack locality identifiers for 2010, we use the share of Syrians at the subdistrict level and therefore cluster standard errors at this level as well. This also allows testing for a different definition of a local labor market. The coefficient of interest here is the interaction between the 2016 round and the share of households in the sub-district that are Syrian. There are no significant employment or unemployment effects for men (Table 8) or women (Table 9). Table 10 reports the results of examining the impact of Syrian refugees on men's job characteristics (and Table 11 does likewise for women). For formality, the estimate on the interaction is positive and statistically significant (in the models with controls and sub-district fixed effects); employed Jordanians are more likely to be engaged in formal work and therefore less likely to be in informal work. However, from our results on employment, we know that they are not less likely to be employed overall, so on the net this represents a shift in the types of jobs Jordanians are doing rather than the net loss of employment. The estimates are statistically significant for women in the model with fixed effects and of a similar magnitude. The tables also show that the effects on occupation and sector are insignificant. Table 12 documents the results for the wage and weekly hours worked models for men (both for waged and non-waged workers). The estimated effect of refugees in 2016 for the wage model is statistically insignificant. This finding holds for both hourly wage and monthly wage. Likewise, for hours 
worked per week, the estimates are statistically insignificant across all specifications. As for women (Table 13), the estimates are also statistically insignificant. 
Table 8. Labor market status (linear probability model), men, cross-sectional data

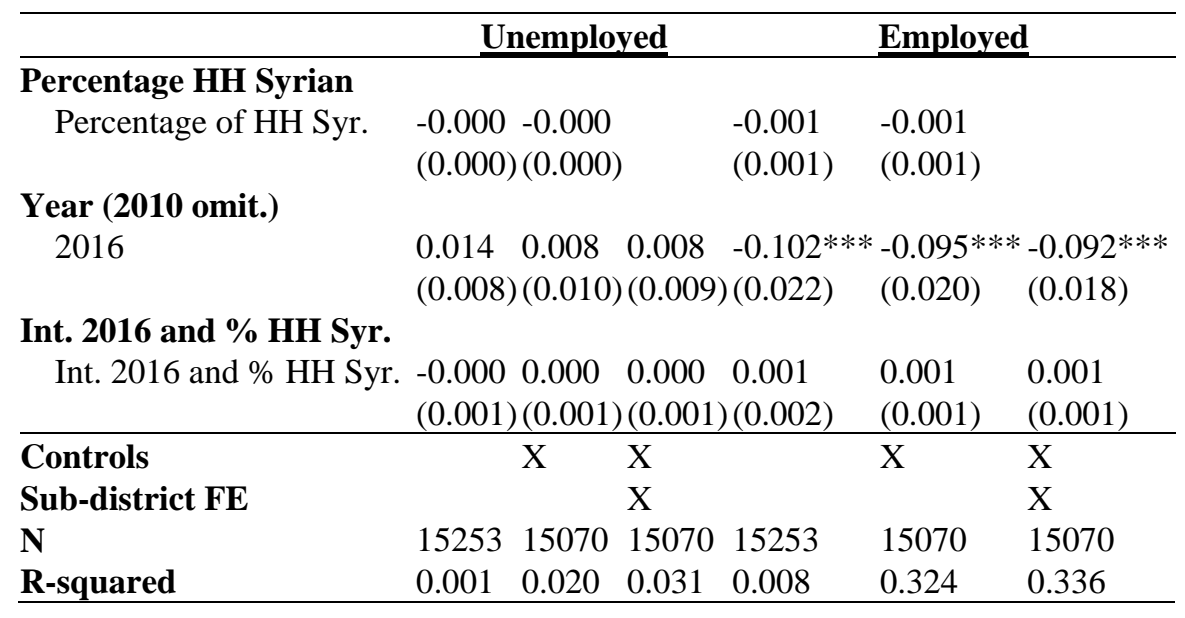

Source: Authors’ calculations based on JLMPS 2010 and 2016

Notes: ${ }^{*} \mathrm{p}<0.05 ;{ }^{* *} \mathrm{p}<0.01 ; * * * \mathrm{p}<0.001$

Controls include education level, mother's education level, father's education level, father's employment status, age, and age squared Standard errors (in parentheses) clustered at the sub-district level 
Table 9. Labor market status (linear probability model), women, cross-sectional data

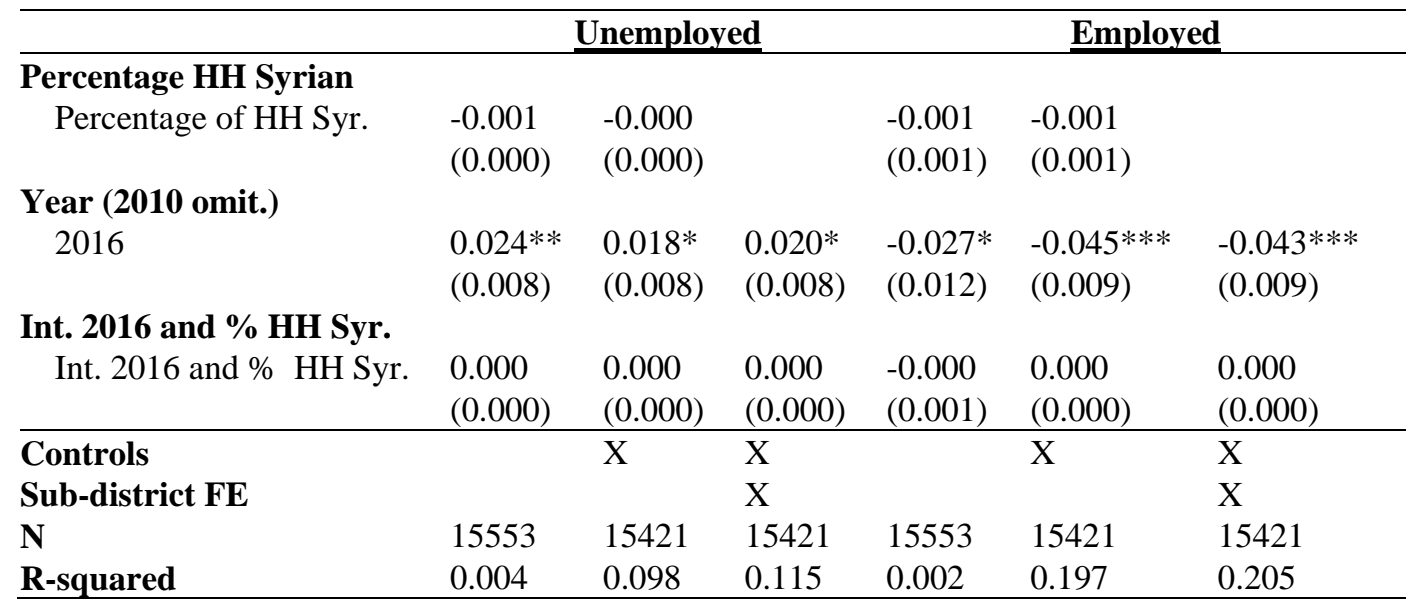

Source: Authors' calculations based on JLMPS 2010 and 2016

Notes: ${ }^{*} \mathrm{p}<0.05 ;{ }^{* *} \mathrm{p}<0.01 ; * * * \mathrm{p}<0.001$

Controls include education level, mother's education level, father's education level, father's employment status, age, and age squared Standard errors (in parentheses) clustered at the sub-district level 
Table 10. Job characteristics (linear probability model), employed men, cross-sectional data

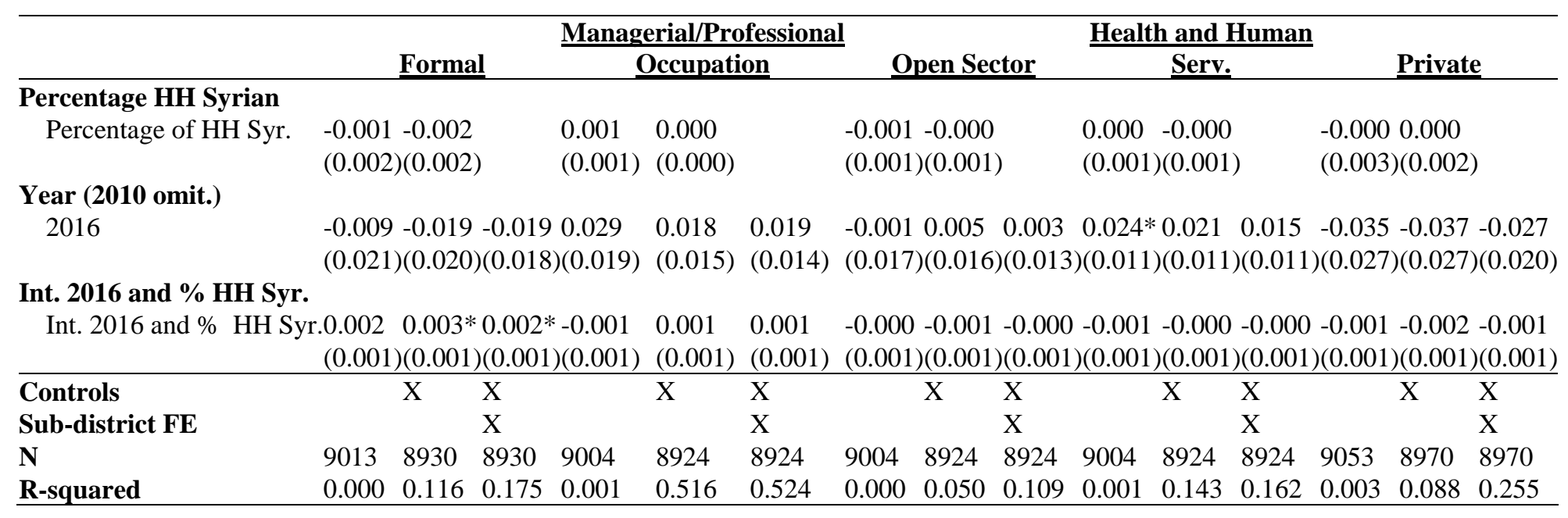

Source: Authors' calculations based on JLMPS 2010 and 2016

Notes: ${ }^{*} \mathrm{p}<0.05 ;{ }^{* *} \mathrm{p}<0.01 ;{ }^{* * *} \mathrm{p}<0.001$

Controls include education level, mother's education level, father's education level, father's employment status, age, and age squared

Standard errors (in parentheses) clustered at the sub-district level 
Table 11. Job characteristics (linear probability model), employed women, cross-sectional data

\begin{tabular}{|c|c|c|c|c|c|c|c|c|c|c|c|c|c|c|c|}
\hline \multirow{2}{*}{ Percentage HH Syrian } & \multicolumn{9}{|c|}{ Managerial/Professional } & \multirow{2}{*}{\multicolumn{4}{|c|}{ Health and Human Serv. }} & \multirow{2}{*}{\multicolumn{2}{|c|}{ Private }} \\
\hline & \multicolumn{3}{|c|}{ Formal } & \multicolumn{3}{|c|}{ Occupation } & \multicolumn{3}{|c|}{ Open Sector } & & & & & & \\
\hline Percentage of HH Syr. & $\begin{array}{l}0.003 \\
(0.002)\end{array}$ & $\begin{array}{l}0.000 \\
(0.001)\end{array}$ & & $\begin{array}{l}0.003 \\
(0.002)\end{array}$ & $\begin{array}{l}0.000 \\
(0.001)\end{array}$ & & $\begin{array}{l}-0.003 \\
(0.002)\end{array}$ & $\begin{array}{l}-0.001 \\
(0.001)\end{array}$ & & $\begin{array}{l}0.002 \\
(0.002)\end{array}$ & $\begin{array}{l}0.001 \\
(0.001)\end{array}$ & & $\begin{array}{l}-0.001 \\
(0.002)\end{array}$ & $\begin{array}{l}-0.000 \\
(0.002)\end{array}$ & \\
\hline Year (2010 omit.) & & & & & & & & & & & & & & & \\
\hline 2016 & $\begin{array}{l}0.013 \\
(0.033)\end{array}$ & $\begin{array}{l}-0.027 \\
(0.025)\end{array}$ & $\begin{array}{l}-0.051^{*} \\
(0.022)\end{array}$ & $\begin{array}{l}0.145^{* *} \\
(0.049)\end{array}$ & $\begin{array}{l}0.073^{*} \\
(0.028)\end{array}$ & $\begin{array}{l}0.068^{*} \\
(0.030)\end{array}$ & $\begin{array}{l}-0.089 * \\
(0.037)\end{array}$ & $\begin{array}{l}-0.031 \\
(0.026)\end{array}$ & $\begin{array}{l}-0.024 \\
(0.025)\end{array}$ & $\begin{array}{l}0.080^{*} \\
(0.033)\end{array}$ & $\begin{array}{l}0.029 \\
(0.034)\end{array}$ & $\begin{array}{l}0.010 \\
(0.032)\end{array}$ & $\begin{array}{l}-0.058 \\
(0.037)\end{array}$ & $\begin{array}{l}-0.017 \\
(0.030)\end{array}$ & $\begin{array}{l}0.032 \\
(0.029)\end{array}$ \\
\hline $\begin{array}{l}\text { Int. } 2016 \text { and \% HH Syr. } \\
\text { Int. } 2016 \text { and \% HH Syr. }\end{array}$ & $\begin{array}{l}0.001 \\
(0.002)\end{array}$ & $\begin{array}{l}0.001 \\
(0.001)\end{array}$ & $\begin{array}{l}0.002 * \\
(0.001)\end{array}$ & $\begin{array}{l}-0.001 \\
(0.004)\end{array}$ & $\begin{array}{l}-0.000 \\
(0.001)\end{array}$ & $\begin{array}{l}0.000 \\
(0.002)\end{array}$ & $\begin{array}{l}0.002 \\
(0.002)\end{array}$ & $\begin{array}{l}0.002 \\
(0.001)\end{array}$ & $\begin{array}{l}0.001 \\
(0.001) \\
\end{array}$ & $\begin{array}{l}-0.003 \\
(0.002)\end{array}$ & $\begin{array}{l}-0.004 \\
(0.002)\end{array}$ & $\begin{array}{l}-0.003 \\
(0.002)\end{array}$ & $\begin{array}{l}0.002 \\
(0.002) \\
\end{array}$ & $\begin{array}{l}0.003 \\
(0.002)\end{array}$ & $\begin{array}{l}0.002 \\
(0.002)\end{array}$ \\
\hline $\begin{array}{l}\text { Controls } \\
\text { Sub-district FE }\end{array}$ & & $\mathrm{X}$ & $\begin{array}{l}\mathrm{X} \\
\mathrm{X}\end{array}$ & & $\mathrm{X}$ & $\begin{array}{l}\mathrm{X} \\
\mathrm{X}\end{array}$ & & $\mathrm{X}$ & $\begin{array}{l}\mathrm{X} \\
\mathrm{X}\end{array}$ & & $\mathrm{X}$ & $\begin{array}{l}\mathrm{X} \\
\mathrm{X}\end{array}$ & & $\mathrm{X}$ & $\begin{array}{l}\mathrm{X} \\
\mathrm{X}\end{array}$ \\
\hline $\begin{array}{l}\text { N } \\
\text { R-squared }\end{array}$ & $\begin{array}{l}1932 \\
0.005\end{array}$ & $\begin{array}{l}1919 \\
0.240\end{array}$ & $\begin{array}{l}1919 \\
0.297\end{array}$ & $\begin{array}{l}2121 \\
0.021\end{array}$ & $\begin{array}{l}2110 \\
0.633\end{array}$ & $\begin{array}{l}2110 \\
0.648\end{array}$ & $\begin{array}{l}2122 \\
0.009\end{array}$ & $\begin{array}{l}2111 \\
0.291\end{array}$ & $\begin{array}{l}2111 \\
0.335\end{array}$ & $\begin{array}{l}2122 \\
0.003\end{array}$ & $\begin{array}{l}2111 \\
0.210\end{array}$ & $\begin{array}{l}2111 \\
0.261\end{array}$ & $\begin{array}{l}2131 \\
0.002\end{array}$ & $\begin{array}{l}2118 \\
0.228\end{array}$ & $\begin{array}{l}2118 \\
0.344\end{array}$ \\
\hline
\end{tabular}

Source: Authors' calculations based on JLMPS 2010 and 2016

Notes: ${ }^{*} \mathrm{p}<0.05 ;{ }^{* *} \mathrm{p}<0.01 ;{ }^{* * *} \mathrm{p}<0.001$

Controls include education level, mother's education level, father's education level, father's employment status, age, and age squared

Standard errors (in parentheses) clustered at the sub-district level 
Table 12. Hours and wages (OLS model), employed (or wage-working) men, cross-sectional data

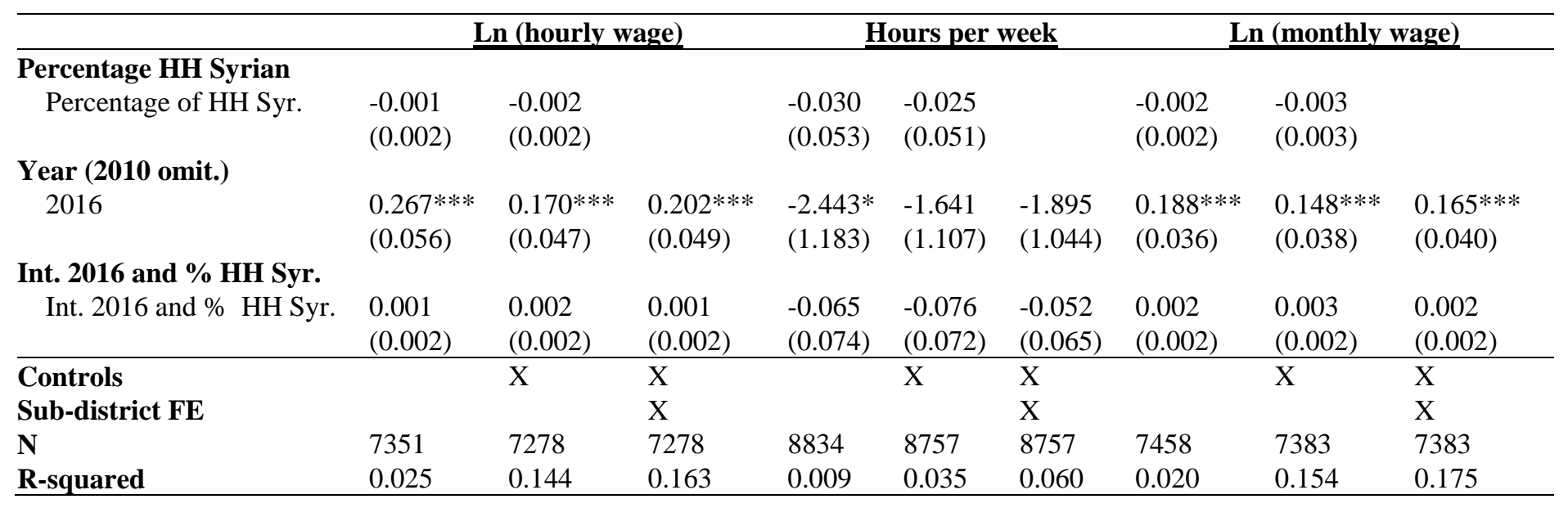

Source: Authors’ calculations based on JLMPS 2010 and 2016

Notes: ${ }^{*} \mathrm{p}<0.05 ; * * \mathrm{p}<0.01 ; * * * \mathrm{p}<0.001$

Controls include education level, mother's education level, father's education level, father's employment status, age, and age squared Standard errors (in parentheses) clustered at the sub-district level 
Table 13. Hours and wages (OLS model), employed (or wage-working) women, cross-sectional data

\begin{tabular}{|c|c|c|c|c|c|c|c|c|c|}
\hline & \multicolumn{3}{|c|}{ Ln (hourly wage) } & \multicolumn{3}{|c|}{ Hours per week } & \multicolumn{3}{|c|}{ Ln (monthly wage) } \\
\hline \multicolumn{10}{|l|}{ Percentage HH Syrian } \\
\hline Percentage of HH Syr. & $\begin{array}{l}0.002 \\
(0.003)\end{array}$ & $\begin{array}{l}-0.002 \\
(0.002)\end{array}$ & & $\begin{array}{l}0.008 \\
(0.031)\end{array}$ & $\begin{array}{l}0.049 \\
(0.031)\end{array}$ & & $\begin{array}{l}0.003 \\
(0.004)\end{array}$ & $\begin{array}{l}0.000 \\
(0.003)\end{array}$ & \\
\hline \multicolumn{10}{|l|}{ Year (2010 omit.) } \\
\hline 2016 & $\begin{array}{l}0.172 \\
(0.092)\end{array}$ & $\begin{array}{l}0.057 \\
(0.055)\end{array}$ & $\begin{array}{l}0.083 \\
(0.062)\end{array}$ & $\begin{array}{l}-0.219 \\
(1.116)\end{array}$ & $\begin{array}{l}0.239 \\
(0.895)\end{array}$ & $\begin{array}{l}0.390 \\
(1.054)\end{array}$ & $\begin{array}{l}0.214^{* * *} \\
(0.060)\end{array}$ & $\begin{array}{l}0.143 * * \\
(0.046)\end{array}$ & $\begin{array}{l}0.145 * * \\
(0.047)\end{array}$ \\
\hline $\begin{array}{l}\text { Int. } 2016 \text { and \% HH Syr. } \\
\text { Int. } 2016 \text { and \% HH Syr. }\end{array}$ & $\begin{array}{l}0.003 \\
(0.004)\end{array}$ & $\begin{array}{l}0.004 \\
(0.004)\end{array}$ & $\begin{array}{l}0.003 \\
(0.004)\end{array}$ & $\begin{array}{l}0.009 \\
(0.052)\end{array}$ & $\begin{array}{l}-0.005 \\
(0.046)\end{array}$ & $\begin{array}{l}0.005 \\
(0.046)\end{array}$ & $\begin{array}{l}0.003 \\
(0.003)\end{array}$ & $\begin{array}{l}0.003 \\
(0.003)\end{array}$ & $\begin{array}{l}0.003 \\
(0.003)\end{array}$ \\
\hline Controls & & $\mathrm{X}$ & $\mathrm{X}$ & & $\mathrm{X}$ & $\mathrm{X}$ & & $\mathrm{X}$ & $\mathrm{X}$ \\
\hline Sub-district FE & & & $\mathrm{X}$ & & & $\mathrm{X}$ & & & $\mathrm{X}$ \\
\hline $\mathbf{N}$ & 1772 & 1762 & 1762 & 1911 & 1899 & 1899 & 1792 & 1782 & 1782 \\
\hline R-squared & 0.014 & 0.227 & 0.276 & 0.000 & 0.119 & 0.170 & 0.038 & 0.207 & 0.281 \\
\hline
\end{tabular}

Source: Authors’ calculations based on JLMPS 2010 and 2016

Notes: ${ }^{*} \mathrm{p}<0.05 ;{ }^{* *} \mathrm{p}<0.01 ; * * * \mathrm{p}<0.001$

Controls include education level, mother's education level, father's education level, father's employment status, age, and age squared Standard errors (in parentheses) clustered at the sub-district level 


\section{Appendix E: Education: Sub-group analyses}

We distinguish individuals based on level of education in Table 14 and Table 15. Most Syrian labor force participants have low levels of education themselves (Assaad, Krafft, and Keo 2018) and are competing for informal and irregular jobs, which are likely to be held by less educated Jordanians (if any). Given the few females who work, we analyze only males for subgroup analyses. We present the panel results throughout our sub-group analyses, since some of the analyses that follow (for instance, by sector) depend on the 2010 year status, and the panel data, unlike the retrospective data, has wage and hours outcomes. We divide our sample into those with a basic education or less and those with secondary or more (as of 2010). There are not significant results for either the less or more educated in terms of employment or unemployment. The formality result becomes insignificant, but is larger for the less educated than the educated, suggesting they are particularly likely to shift out of informal work and into formal work. The significant hourly wage effect persists (and is larger) for the less educated, and is positive but insignificant for the more educated. The decrease in private sector (and increase in public sector work) is significant only for the more educated, unsurprising given the requirements of most public sector jobs. Overall, our results do not suggest unique negative effects of the refugee influx for the less educated. 
Table 14. Labor market outcomes, hours, and wages (fixed effects linear probability and OLS models), by education (in 2010), men, panel data

\begin{tabular}{|c|c|c|c|c|c|c|c|c|c|c|}
\hline & \multicolumn{2}{|c|}{ Unemployed } & \multicolumn{2}{|c|}{ Employed } & \multicolumn{2}{|c|}{ Ln (hourly wage) } & \multicolumn{2}{|c|}{ Hours per week } & \multicolumn{2}{|c|}{$\frac{\text { Ln (monthly }}{\text { wage) }}$} \\
\hline & $\frac{\text { Less }}{\text { ed. }}$ & $\frac{\text { More }}{\text { ed. }}$ & $\frac{\text { Less }}{\text { ed. }}$ & $\frac{\text { More }}{\text { ed. }}$ & $\frac{\text { Less }}{\text { ed. }}$ & $\frac{\text { More }}{\text { ed. }}$ & $\frac{\text { Less }}{\text { ed. }}$ & $\begin{array}{l}\text { More } \\
\text { ed. }\end{array}$ & $\frac{\text { Less }}{\text { ed. }}$ & $\frac{\text { More }}{\text { ed. }}$ \\
\hline \multicolumn{11}{|l|}{ Year (2010 omit.) } \\
\hline 2016 & $\begin{array}{l}0.044 \\
(0.054)\end{array}$ & $\begin{array}{l}-0.002 \\
(0.039)\end{array}$ & $\begin{array}{l}-0.106 \\
(0.065)\end{array}$ & $\begin{array}{l}-0.046 \\
(0.055)\end{array}$ & $\begin{array}{l}0.181 \\
(0.164)\end{array}$ & $\begin{array}{l}0.469 * * \\
(0.166)\end{array}$ & $\begin{array}{l}-0.211 \\
(2.009)\end{array}$ & $\begin{array}{l}-6.705 \\
(3.705)\end{array}$ & $\begin{array}{l}-0.088 \\
(0.216)\end{array}$ & $\begin{array}{l}0.371 \\
(0.365)\end{array}$ \\
\hline $\begin{array}{l}\text { Int. year and \% HH Syrian } \\
\text { Int. } 2016 \text { and \% HH Syr. }\end{array}$ & $\begin{array}{l}-0.000 \\
(0.001)\end{array}$ & $\begin{array}{l}0.002 \\
(0.001)\end{array}$ & $\begin{array}{l}0.001 \\
(0.002)\end{array}$ & $\begin{array}{l}-0.001 \\
(0.003)\end{array}$ & $\begin{array}{l}0.013 * \\
(0.006)\end{array}$ & $\begin{array}{l}0.005 \\
(0.005)\end{array}$ & $\begin{array}{l}-0.207 \\
(0.144)\end{array}$ & $\begin{array}{l}-0.074 \\
(0.136)\end{array}$ & $\begin{array}{l}0.007 \\
(0.005)\end{array}$ & $\begin{array}{l}-0.001 \\
(0.004)\end{array}$ \\
\hline $\mathrm{N}$ & 4755 & 2608 & 4776 & 2618 & 2301 & 1562 & 2840 & 1837 & 2337 & 1587 \\
\hline
\end{tabular}

Source: Authors’ calculations based on JLMPS 2010 - JLMPS 2016 panel

Notes: ${ }^{*} \mathrm{p}<0.05 ;{ }^{* *} \mathrm{p}<0.01 ;{ }^{* * *} \mathrm{p}<0.001$

Controlling for age and age squared in year

Standard errors (in parentheses) clustered at the locality level 
Table 15. Job characteristics (fixed effects linear probability models), by education (in 2010), employed men, panel data

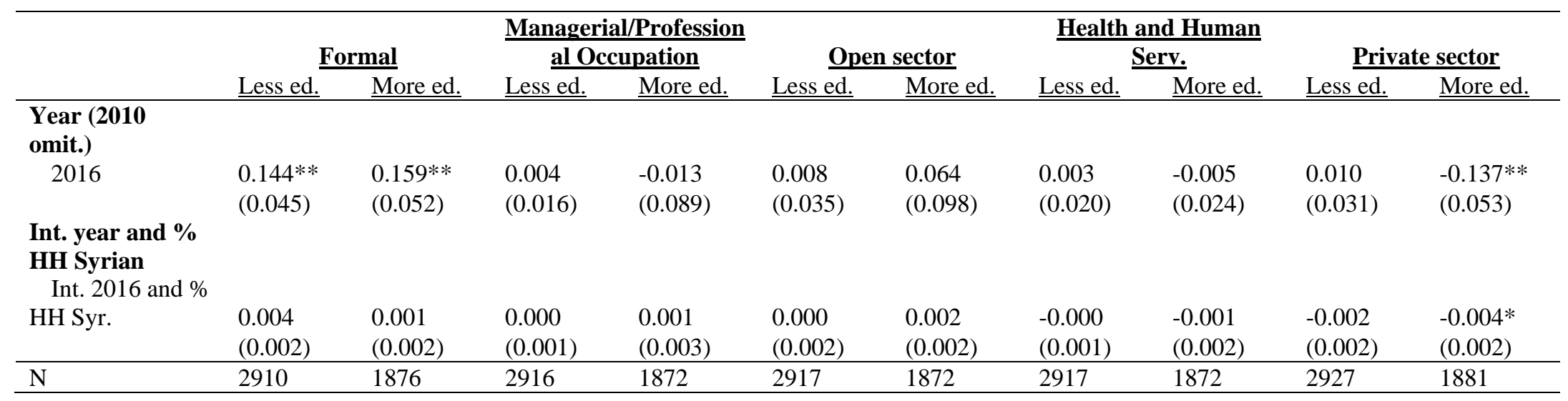

Source: Authors’ calculations based on JLMPS 2010 - JLMPS 2016 panel

Notes: ${ }^{*} \mathrm{p}<0.05 ;{ }^{* *} \mathrm{p}<0.01 ;{ }^{* * *} \mathrm{p}<0.001$

Controlling for age and age squared in year

Standard errors (in parentheses) clustered at the locality level 


\section{Appendix F: Sector: Sub-group analyses}

We examine the effects of employment by the sector of work in 2010 in Table 16 and Table 17. Those in the private sector in 2010 would be particularly likely to experience competition from incoming Syrians. Again, we present results only for men, since few women work. We use the panel data analyses for the best coverage of outcomes as well as being able to condition on 2010 status. Keeping in mind the selected nature of the sample-we are comparing those employed in the private sector and those employed in the public sector, so setting aside those not employed in 2010 — there are interesting unemployment and employment effects. Those who were in the private sector and experienced a greater local labor market shock are significantly less likely to be unemployed. Those who had a greater shock and were in the public sector are significantly more likely to be employed (the coefficient for those in the private sector is of similar magnitude, albeit insignificant). The formality effects are insignificant, but of greater magnitude in the private sector. The increase in hourly wages is of a similar magnitude across sectors, but only significant in the public sector, where there was also a small (0.2) but significant reduction in hours per week. There was a significant effect on the probability of being a manager or professional only in the public sector. Curiously, there was a significant increase in being in the open sector for those in the private sector in 2010. It may be that the Jordan Compact is creating greater employment opportunities for Jordanians in these activities, as well as the Syrians who can acquire work permits in this sector. No other results were significant, but the number of significant results by sector, particularly given the further division of the sample, suggests that the Syrian refugee influx has had different effects, largely slight positive ones, across sectors. 
Table 16. Labor market outcomes, hours, and wages (fixed effects linear probability and OLS models), by sector (in 2010), men, panel data

\begin{tabular}{|c|c|c|c|c|c|c|c|c|c|c|}
\hline & \multicolumn{2}{|c|}{ Unemployed } & \multicolumn{2}{|c|}{ Employed } & \multicolumn{2}{|c|}{ Ln (hourly wage) } & \multicolumn{2}{|c|}{ Hours per week } & \multicolumn{2}{|c|}{ Ln (monthly wage) } \\
\hline & Public & Private & Public & Private & Public & $\underline{\text { Private }}$ & Public & Private & Public & Private \\
\hline \multicolumn{11}{|l|}{ Year (2010 omit.) } \\
\hline 2016 & $\begin{array}{l}0.043^{* *} \\
(0.016)\end{array}$ & $\begin{array}{l}0.056^{* * *} \\
(0.011)\end{array}$ & $\begin{array}{l}-0.303^{* * *} \\
(0.045)\end{array}$ & $\begin{array}{l}-0.245^{* * *} \\
(0.032)\end{array}$ & $\begin{array}{l}0.330 * * \\
(0.121)\end{array}$ & $\begin{array}{l}0.503 * * \\
(0.158)\end{array}$ & $\begin{array}{l}2.740 \\
(2.281)\end{array}$ & $\begin{array}{l}-6.712 * \\
(2.805)\end{array}$ & $\begin{array}{l}0.266 * * \\
(0.090)\end{array}$ & $\begin{array}{l}0.021 \\
(0.250)\end{array}$ \\
\hline \multicolumn{11}{|l|}{ Int. year and \% HH Syrian } \\
\hline Int. 2016 and \% HH Syr. & $\begin{array}{l}-0.001 \\
(0.001) \\
\end{array}$ & $\begin{array}{l}-0.002 * * \\
(0.001)\end{array}$ & $\begin{array}{l}0.003^{*} \\
(0.002) \\
\end{array}$ & $\begin{array}{l}0.003 \\
(0.002) \\
\end{array}$ & $\begin{array}{l}0.008 * \\
(0.004) \\
\end{array}$ & $\begin{array}{l}0.009 \\
(0.010) \\
\end{array}$ & $\begin{array}{l}-0.207 * \\
(0.085) \\
\end{array}$ & $\begin{array}{l}0.037 \\
(0.207) \\
\end{array}$ & $\begin{array}{l}0.003 \\
(0.002) \\
\end{array}$ & $\begin{array}{l}0.005 \\
(0.012) \\
\end{array}$ \\
\hline $\mathrm{N}$ & 2356 & 2364 & 2357 & 2384 & 2012 & 1313 & 2054 & 2008 & 2036 & 1332 \\
\hline
\end{tabular}

Source: Authors' calculations based on JLMPS 2010 - JLMPS 2016 panel

Notes: ${ }^{*} \mathrm{p}<0.05 ;{ }^{* *} \mathrm{p}<0.01 ;{ }^{* * *} \mathrm{p}<0.001$

Controlling for age and age squared in year

Standard errors (in parentheses) clustered at the locality level 
Table 17. Job characteristics (fixed effects linear probability models), by sector (in 2010), employed men, panel data

\begin{tabular}{|c|c|c|c|c|c|c|c|c|c|c|}
\hline & \multirow{2}{*}{\multicolumn{2}{|c|}{ Formal }} & \multicolumn{4}{|c|}{ Managerial/Professional } & \multicolumn{2}{|c|}{ Health and Human } & \multirow{2}{*}{\multicolumn{2}{|c|}{ Private sector }} \\
\hline & & & & pation & & sector & & erv. & & \\
\hline & Public & Private & Public & Private & Public & Private & Public & Private & Public & Private \\
\hline \multicolumn{11}{|l|}{ Year (2010 omit.) } \\
\hline 2016 & $\begin{array}{l}0.063 \\
(0.074)\end{array}$ & $\begin{array}{l}0.187 * * * \\
(0.047)\end{array}$ & $\begin{array}{l}0.051 \\
(0.028)\end{array}$ & $\begin{array}{l}0.041 \\
(0.031)\end{array}$ & $\begin{array}{l}-0.016 \\
(0.093)\end{array}$ & $\begin{array}{l}-0.065 \\
(0.044)\end{array}$ & $\begin{array}{l}-0.017 \\
(0.023)\end{array}$ & $\begin{array}{l}0.013 \\
(0.024)\end{array}$ & $\begin{array}{l}-0.040 \\
(0.073)\end{array}$ & $\begin{array}{l}-0.055^{* *} \\
(0.020)\end{array}$ \\
\hline \multicolumn{11}{|l|}{ Int. year and \% HH Syrian } \\
\hline Int. 2016 and \% HH Syr. & $\begin{array}{l}0.001 \\
(0.001)\end{array}$ & $\begin{array}{l}0.004 \\
(0.003)\end{array}$ & $\begin{array}{l}0.003^{*} \\
(0.001)\end{array}$ & $\begin{array}{l}-0.002 \\
(0.003)\end{array}$ & $\begin{array}{l}0.000 \\
(0.001)\end{array}$ & $\begin{array}{l}0.005^{*} \\
(0.002)\end{array}$ & $\begin{array}{l}-0.000 \\
(0.002)\end{array}$ & $\begin{array}{l}-0.002 \\
(0.001)\end{array}$ & $\begin{array}{l}-0.001 \\
(0.001)\end{array}$ & $\begin{array}{l}-0.002 \\
(0.002)\end{array}$ \\
\hline $\mathrm{N}$ & 2081 & 2063 & 2080 & 2063 & 2082 & 2063 & 2082 & 2063 & 2089 & 2070 \\
\hline
\end{tabular}

Source: Authors’ calculations based on JLMPS 2010 - JLMPS 2016 panel

Notes: ${ }^{*} \mathrm{p}<0.05 ;{ }^{* *} \mathrm{p}<0.01 ;{ }^{* * *} \mathrm{p}<0.001$

Controlling for age and age squared in year

Standard errors (in parentheses) clustered at the locality level 


\section{Appendix G: Amman versus elsewhere: Sub-group analyses}

Amman is the capital of Jordan - the seat of government - and also home to $39 \%$ of Jordan’s population. Given these characteristics, Amman may also have a somewhat different labor market and labor market response to the influx than elsewhere. We therefore undertook sub-group analyses splitting the sample into Amman and “not Amman” (everywhere else). We present the results for men in our main panel estimation, comparing Amman and "not Amman" in Table 18 and Table 19. In neither Amman or outside Amman is there a negative effect of the influx on employment or unemployment. Among the employed, shifts into more formal work and reductions in private sector/increases in public sector work occur in both areas but are larger and significant in Amman. 
Table 18. Labor market outcomes, hours, and wages (fixed effects linear probability and OLS models), by Amman (in 2010), men, panel data

\begin{tabular}{|c|c|c|c|c|c|c|c|c|c|c|}
\hline & \multicolumn{2}{|c|}{ Unemployed } & \multicolumn{2}{|c|}{ Employed } & \multicolumn{2}{|c|}{ Ln (hourly wage) } & \multicolumn{2}{|c|}{ Hours per week } & \multicolumn{2}{|c|}{ Ln (monthly wage) } \\
\hline & 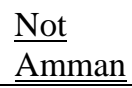 & $\underline{\text { Amman }}$ & 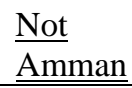 & $\underline{\text { Amman }}$ & $\underline{\text { Not }}$ & $\underline{\text { Amman }}$ & 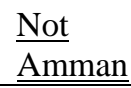 & $\underline{\text { Amman }}$ & 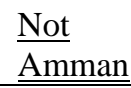 & $\underline{\text { Amman }}$ \\
\hline Year (2010 omit.) & & & & & & & & & & \\
\hline 2016 & $\begin{array}{l}0.087 \\
(0.081)\end{array}$ & $\begin{array}{l}-0.012 \\
(0.037)\end{array}$ & $\begin{array}{l}0.010 \\
(0.106)\end{array}$ & $\begin{array}{l}-0.026 \\
(0.064)\end{array}$ & $\begin{array}{l}0.353^{* *} \\
(0.110)\end{array}$ & $\begin{array}{l}0.237 \\
(0.241)\end{array}$ & $\begin{array}{l}-1.208 \\
(2.504)\end{array}$ & $\begin{array}{l}-5.425 \\
(4.461)\end{array}$ & $\begin{array}{l}0.128 \\
(0.154)\end{array}$ & $\begin{array}{l}0.326 \\
(0.391)\end{array}$ \\
\hline $\begin{array}{l}\text { Int. year and \% HH } \\
\text { Syrian }\end{array}$ & & & & & & & & & & \\
\hline $\begin{array}{l}\text { Int. } 2016 \text { and \% HH } \\
\text { Syr. }\end{array}$ & $\begin{array}{l}0.000 \\
(0.001)\end{array}$ & $\begin{array}{l}0.004 \\
(0.003)\end{array}$ & $\begin{array}{l}0.001 \\
(0.002)\end{array}$ & $\begin{array}{l}-0.007 \\
(0.006)\end{array}$ & $\begin{array}{l}0.007 \\
(0.003)\end{array}$ & $\begin{array}{l}0.034 \\
(0.027)\end{array}$ & $\begin{array}{l}-0.131 \\
(0.090)\end{array}$ & $\begin{array}{l}-0.077 \\
(0.366)\end{array}$ & $\begin{array}{l}0.004 \\
(0.003)\end{array}$ & $\begin{array}{l}0.006 \\
(0.028)\end{array}$ \\
\hline $\mathbf{N}$ & 5966 & 1397 & 5992 & 1402 & 3158 & 705 & 3769 & 908 & 3193 & 731 \\
\hline
\end{tabular}

Source: Authors’ calculations based on JLMPS 2010 - JLMPS 2016 panel

Notes: ${ }^{*} \mathrm{p}<0.05 ;{ }^{* *} \mathrm{p}<0.01 ;{ }^{* * *} \mathrm{p}<0.001$

Controlling for age and age squared in year

Standard errors (in parentheses) clustered at the locality level 
Table 19. Job characteristics (fixed effects linear probability models), by Amman (in 2010), employed men, panel data

\begin{tabular}{|c|c|c|c|c|c|c|c|c|c|c|}
\hline & \multirow{2}{*}{\multicolumn{2}{|c|}{ Formal }} & \multicolumn{2}{|c|}{ Managerial/Professiona } & & & \multicolumn{2}{|c|}{ Health and Human } & \multirow{2}{*}{\multicolumn{2}{|c|}{ Private sector }} \\
\hline & & & \multicolumn{2}{|c|}{ I Occupation } & \multicolumn{2}{|c|}{$\underline{\text { Open sector }}$} & \multicolumn{2}{|c|}{ Serv. } & & \\
\hline & $\begin{array}{l}\text { Not } \\
\text { Amman }\end{array}$ & Amman & $\begin{array}{l}\text { Not } \\
\text { Amman }\end{array}$ & Amman & $\begin{array}{l}\text { Not } \\
\text { Amman }\end{array}$ & Amman & $\begin{array}{l}\text { Not } \\
\text { Amman }\end{array}$ & Amman & $\begin{array}{l}\text { Not } \\
\text { Amman } \\
\end{array}$ & Amman \\
\hline Year (2010 omit.) & & & & & & & & & & \\
\hline 2016 & $\begin{array}{l}0.053 \\
(0.070)\end{array}$ & $\begin{array}{l}0.111^{*} \\
(0.044)\end{array}$ & $\begin{array}{l}0.121^{* * *} \\
(0.035)\end{array}$ & $\begin{array}{l}-0.039 \\
(0.098)\end{array}$ & $\begin{array}{l}-0.080 \\
(0.109)\end{array}$ & $\begin{array}{l}-0.084 \\
(0.105)\end{array}$ & $\begin{array}{l}-0.068 \\
(0.068)\end{array}$ & $\begin{array}{l}0.029 \\
(0.046)\end{array}$ & $\begin{array}{l}-0.068 \\
(0.129)\end{array}$ & $\begin{array}{l}0.078 \\
(0.054)\end{array}$ \\
\hline $\begin{array}{l}\text { Int. year and \% HH } \\
\text { Syrian } \\
\quad \text { Int. } 2016 \text { and \% HH }\end{array}$ & & & & & & & & & & \\
\hline Syr. & $\begin{array}{l}0.002 \\
(0.001)\end{array}$ & $\begin{array}{l}0.011^{*} \\
(0.004)\end{array}$ & $\begin{array}{l}0.000 \\
(0.001)\end{array}$ & $\begin{array}{l}0.005 \\
(0.010)\end{array}$ & $\begin{array}{l}0.001 \\
(0.001)\end{array}$ & $\begin{array}{l}0.007 \\
(0.008) \\
\end{array}$ & $\begin{array}{l}-0.000 \\
(0.001)\end{array}$ & $\begin{array}{l}-0.003 \\
(0.004)\end{array}$ & $\begin{array}{l}-0.001 \\
(0.001)\end{array}$ & $\begin{array}{l}-0.010 * \\
(0.004) \\
\end{array}$ \\
\hline $\mathbf{N}$ & 3832 & 954 & 3835 & 953 & 3838 & 951 & 3838 & 951 & 3852 & 956 \\
\hline
\end{tabular}

Source: Authors’ calculations based on JLMPS 2010 - JLMPS 2016 panel

Notes: ${ }^{*} \mathrm{p}<0.05$; ${ }^{* *} \mathrm{p}<0.01$; ${ }^{* * *} \mathrm{p}<0.001$

Controlling for age and age squared in year

Standard errors (in parentheses) clustered at the locality level 


\section{Appendix H: Entrants: Sub-Group Analyses}

One further model is used to consider the potentially disproportionate impact of Syrian refugees specifically on labor market entrants in Jordan. Unemployment is primarily a new entrant phenomenon in Jordan. Labor markets are rigid, such that initial entry is highly deterministic of subsequent labor market outcomes (Amer 2014; Assaad and Krafft 2016; Mryyan 2014). Therefore, one of the sub-groups we examine as potentially disproportionately impacted by the Syrian refugee influx are new entrants. In this section, we examine only labor market entrants, those who left school or turned age 15 in the preceding five years, whichever was later, using the repeated cross-section data. We use the repeated cross-section rather than our preferred panel because we cannot observe any employment characteristics for those who were in school in 2010 and therefore could not estimate our models. The entrants are therefore those who left school or turned 15 in 2005-2009 or 2012-2016. As elsewhere, we focus our results on men. Table 20, Table 21, and Table 22 present the results of these models. In our preferred specification (including controls and sub-district fixed effects) there are no significant effects. 
Table 20. Entrants: Labor market status (linear probability model), men, cross-sectional data

\begin{tabular}{|c|c|c|c|c|c|c|}
\hline & \multicolumn{3}{|c|}{ Unemployed } & \multicolumn{3}{|c|}{ Employed } \\
\hline \multicolumn{7}{|l|}{ Percentage HH Syrian } \\
\hline Percentage of HH Syr. & $\begin{array}{l}-0.000 \\
(0.001)\end{array}$ & $\begin{array}{l}-0.001 \\
(0.001)\end{array}$ & & $\begin{array}{l}0.000 \\
(0.002)\end{array}$ & $\begin{array}{l}0.000 \\
(0.001)\end{array}$ & \\
\hline \multicolumn{7}{|l|}{ Year (2010 omit.) } \\
\hline 2016 & $\begin{array}{l}0.029 \\
(0.030)\end{array}$ & $\begin{array}{l}0.025 \\
(0.036)\end{array}$ & $\begin{array}{l}0.026 \\
(0.035)\end{array}$ & $\begin{array}{l}-0.225^{* * *} \\
(0.033)\end{array}$ & $\begin{array}{l}-0.193 * * * \\
(0.039)\end{array}$ & $\begin{array}{l}-0.194 * * * \\
(0.042)\end{array}$ \\
\hline $\begin{array}{l}\text { Int. } 2016 \text { and \% HH Syr. } \\
\text { Int. } 2016 \text { and \% HH Syr. }\end{array}$ & $\begin{array}{l}-0.002 \\
(0.002)\end{array}$ & $\begin{array}{l}-0.001 \\
(0.002)\end{array}$ & $\begin{array}{l}-0.001 \\
(0.002)\end{array}$ & $\begin{array}{l}0.002 \\
(0.002)\end{array}$ & $\begin{array}{l}0.001 \\
(0.002)\end{array}$ & $\begin{array}{l}0.002 \\
(0.002)\end{array}$ \\
\hline Controls & & $\mathrm{X}$ & $\mathrm{X}$ & & $\mathrm{X}$ & $\mathrm{X}$ \\
\hline Sub-district FE & & & $\mathrm{X}$ & & & $\mathrm{X}$ \\
\hline $\mathrm{N}$ & 2138 & 2096 & 2096 & 2138 & 2096 & 2096 \\
\hline R-squared & 0.001 & 0.044 & 0.089 & 0.043 & 0.142 & 0.192 \\
\hline
\end{tabular}

Source: Authors’ calculations based on JLMPS 2010 and 2016

Notes: ${ }^{*} \mathrm{p}<0.05 ; * * \mathrm{p}<0.01 ; * * * \mathrm{p}<0.001$

Controls include education level, mother's education level, father's education level, father's employment status, age, and age squared

Standard errors (in parentheses) clustered at the sub-district level 
Table 21. Entrants: Job characteristics (linear probability model), employed men, cross-sectional data

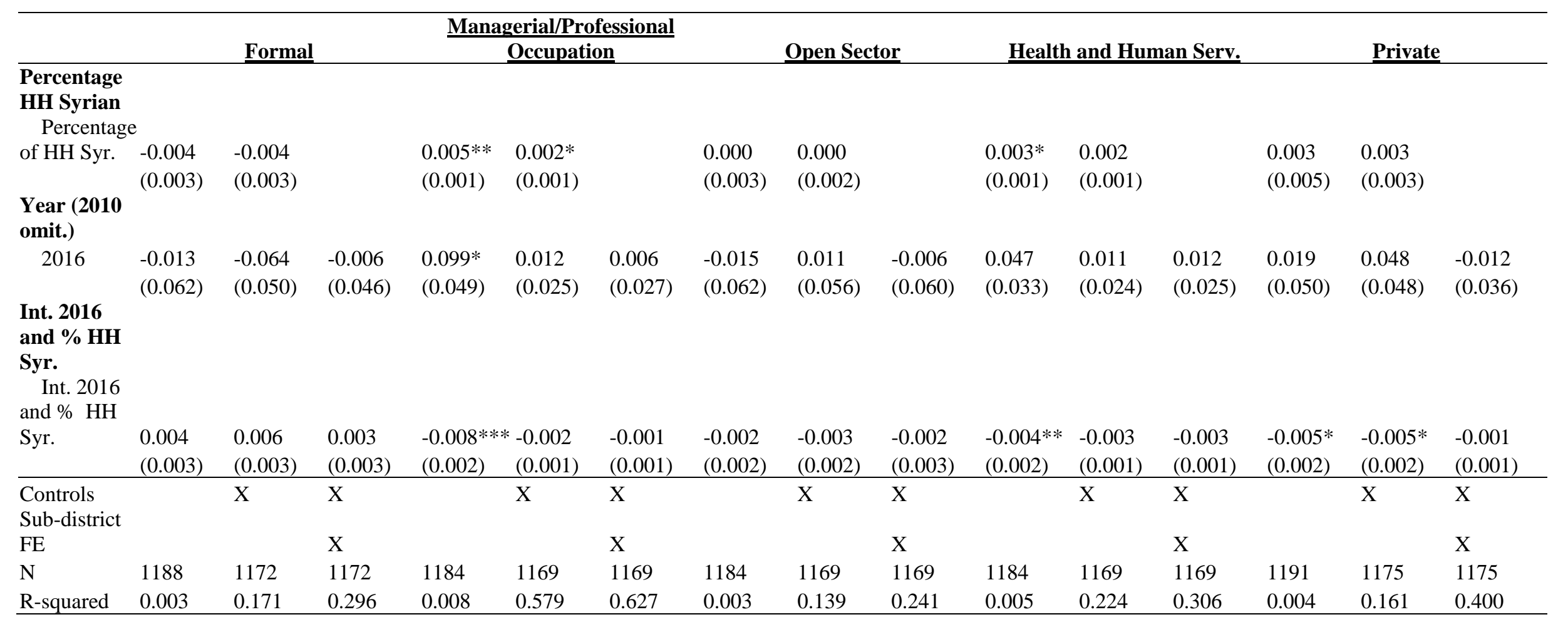

Source: Authors' calculations based on JLMPS 2010 and 2016

Notes: ${ }^{*} \mathrm{p}<0.05 ;{ }^{* *} \mathrm{p}<0.01 ;{ }^{* * *} \mathrm{p}<0.001$

Controls include education level, mother's education level, father's education level, father's employment status, age, and age squared

Standard errors (in parentheses) clustered at the sub-district level 
Table 22. Entrants: Hours and wages (OLS model), employed (or wage-working) men, cross-sectional data

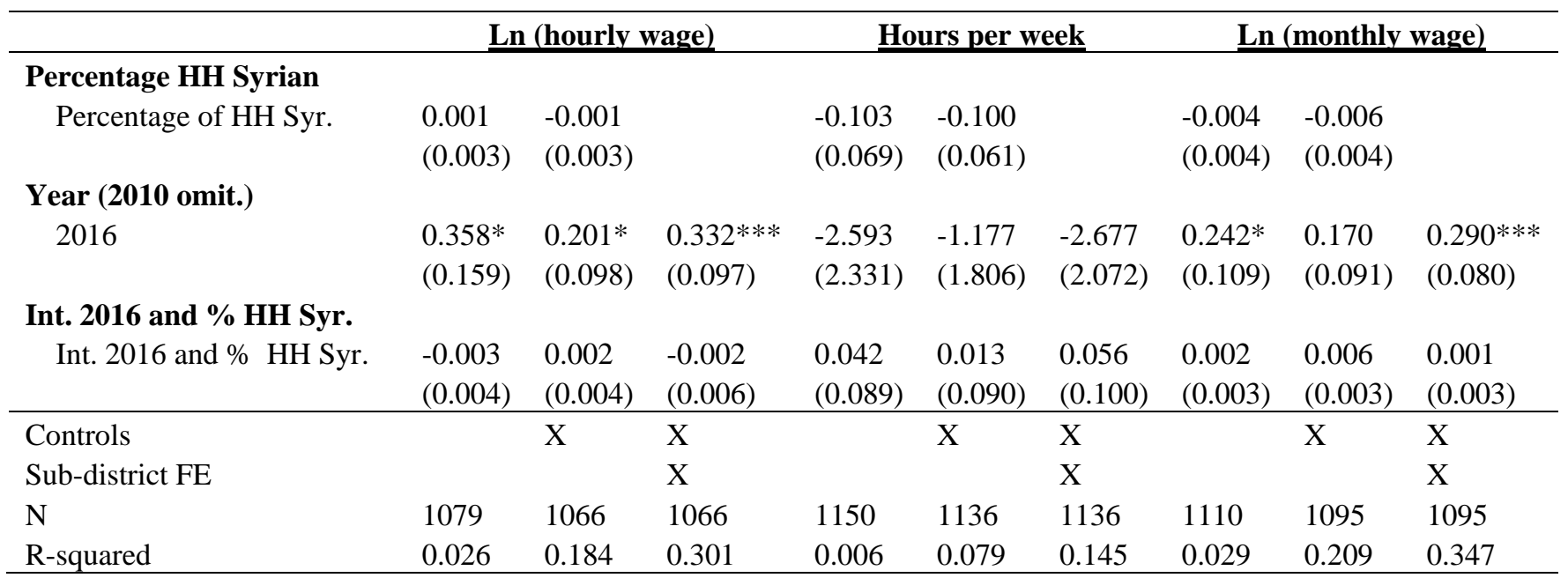

Source: Authors’ calculations based on JLMPS 2010 and 2016

Notes: ${ }^{*} \mathrm{p}<0.05 ;{ }^{* *} \mathrm{p}<0.01 ; * * * \mathrm{p}<0.001$

Controls include education level, mother's education level, father's education level, father's employment status, age, and age squared Standard errors (in parentheses) clustered at the sub-district level 


\section{Appendix I: Entrants: School-to-work transitions}

Since unemployment is a primarily new entrant phenomenon in Jordan and early outcomes are highly deterministic of subsequent trajectory, the school to work transition of Jordanian youth is of great concern. In this appendix we analyze school-to-work transitions over the 2004-2016 period, ${ }^{1}$ similar to the retrospective analyses, but with the outcome here being the probability of obtaining a first job.

We specifically examine the duration of the school-to-work transitions using a complementary log-log discrete-time hazard model. The underlying event. $T$, we are interested in modeling (in this case, obtaining a first job) occurs at some point in time $d$. In this case, time is duration from school exit or age 15 , whichever is later. ${ }^{2}$ Duration-time, $d$, is distinct from calendar time, $t$. However, some individuals are censored and have not yet obtained a first job. Thus, we must use survival analysis, based on the idea of a hazard, $h_{i d}$, namely:

$$
h_{i d}=\operatorname{Pr}\left(T_{d}=d \mid T_{d} \geq d\right)
$$

The hazard is the probability of individual $i$ obtaining a first job at a particular duration, given that an individual has not yet done so. In a multivariate context, this gets modeled as the complementary log-log difference-in-difference model:

$$
h_{i d}=1-\exp \left[-\exp \left(\mu_{d} d+\alpha_{j} X_{i j}+\delta_{t} t+\gamma S_{l}+\theta_{t} t * S_{l}\right)\right]
$$

Here the coefficients, once exponentiated, are hazard ratios, proportionately multiplying the baseline hazards, $\mu_{d}$.

\footnotetext{
${ }^{1}$ Here we omit 2017 since we do not observe school exit in 2017 in our sample, since primary fielding finished in April.

${ }^{2}$ We restrict our analyses to those who exited in 2004-2016, parallel to the time frame for our retrospective analyses.
} 
We estimate the effect of Syrians in each year, which allows us to test for parallel trends in this model, as in the retrospective data, as well as estimate the effect itself. Table 23 shows the results in terms of hazard ratios; a hazard ratio less than one means a slower transition from school to work (specifically, a lower probability of obtaining a first job in each year if one has not yet done so) while a hazard ratio greater than one is a faster transition (or higher probability). The models are presented first without and then with controls. All specifications include the baseline hazard, the probability of obtaining a job each year out from age 15 or school exit.

There are no significant refugee impacts for men, although after adding controls, there is some evidence that areas that had a larger refugee influx did, back in 2005/2006, have slower school to work transitions, non-parallel trends, with joint significance for the 2004-2009 interactions. Overall, there does not appear to have been a negative impact of the refugee influx on school-to-work transitions. 
Table 23. School-to-work transition (hazard ratios from a complementary log-log discrete time hazard model), men, retrospective data for 2004-2016

\begin{tabular}{|c|c|c|}
\hline \multicolumn{3}{|l|}{ Year (2010 omit.) } \\
\hline 2004 & $\begin{array}{l}1.189 \\
(0.430)\end{array}$ & $\begin{array}{l}1.280 \\
(0.470)\end{array}$ \\
\hline 2005 & $\begin{array}{l}1.051 \\
(0.252)\end{array}$ & $\begin{array}{l}1.258 \\
(0.299)\end{array}$ \\
\hline 2006 & $\begin{array}{l}1.070 \\
(0.321)\end{array}$ & $\begin{array}{l}1.256 \\
(0.377)\end{array}$ \\
\hline 2007 & $\begin{array}{l}0.820 \\
(0.226)\end{array}$ & $\begin{array}{l}0.870 \\
(0.243)\end{array}$ \\
\hline 2008 & $\begin{array}{l}0.451^{* *} \\
(0.133)\end{array}$ & $\begin{array}{l}0.478 * \\
(0.141)\end{array}$ \\
\hline 2009 & $\begin{array}{l}0.540^{*} \\
(0.155)\end{array}$ & $\begin{array}{l}0.537^{*} \\
(0.161)\end{array}$ \\
\hline 2011 & $\begin{array}{l}0.737 \\
(0.143)\end{array}$ & $\begin{array}{l}0.745 \\
(0.145)\end{array}$ \\
\hline 2012 & $\begin{array}{l}0.609 \\
(0.245)\end{array}$ & $\begin{array}{l}0.700 \\
(0.257)\end{array}$ \\
\hline 2013 & $\begin{array}{l}0.851 \\
(0.238)\end{array}$ & $\begin{array}{l}0.930 \\
(0.251)\end{array}$ \\
\hline 2014 & $\begin{array}{l}0.545^{*} \\
(0.137)\end{array}$ & $\begin{array}{l}0.609^{*} \\
(0.145)\end{array}$ \\
\hline 2015 & $\begin{array}{l}0.777 \\
(0.230)\end{array}$ & $\begin{array}{l}0.855 \\
(0.244)\end{array}$ \\
\hline 2016 & $\begin{array}{l}0.753 \\
(0.163)\end{array}$ & $\begin{array}{l}0.759 \\
(0.169)\end{array}$ \\
\hline Percentage HH Syrian & & \\
\hline Percentage of HH Syr. & $\begin{array}{l}1.000 \\
(0.013)\end{array}$ & $\begin{array}{l}1.004 \\
(0.013)\end{array}$ \\
\hline Int. year and \% HH Syr. & & \\
\hline Int. 2004 and \% HH Syr. & $\begin{array}{l}0.969 \\
(0.036)\end{array}$ & $\begin{array}{l}0.970 \\
(0.034)\end{array}$ \\
\hline Int. 2005 and \% HH Syr. & $\begin{array}{l}0.975 \\
(0.017)\end{array}$ & $\begin{array}{l}0.965^{*} \\
(0.017)\end{array}$ \\
\hline Int. 2006 and \% HH Syr. & $\begin{array}{l}0.966 \\
(0.022)\end{array}$ & $\begin{array}{l}0.957^{*} \\
(0.021)\end{array}$ \\
\hline Int. 2007 and \% HH Syr. & $\begin{array}{l}1.011 \\
(0.021)\end{array}$ & $\begin{array}{l}1.005 \\
(0.020)\end{array}$ \\
\hline Int. 2008 and \% HH Syr. & $\begin{array}{l}1.030 \\
(0.024)\end{array}$ & $\begin{array}{l}1.028 \\
(0.024)\end{array}$ \\
\hline Int. 2009 and \% HH Syr. & $\begin{array}{l}1.014 \\
(0.019)\end{array}$ & $\begin{array}{l}1.013 \\
(0.018)\end{array}$ \\
\hline Int. 2011 and \% HH Syr. & $\begin{array}{l}1.009 \\
(0.014)\end{array}$ & $\begin{array}{l}1.009 \\
(0.014)\end{array}$ \\
\hline Int. 2012 and \% HH Syr. & $\begin{array}{l}1.008 \\
(0.029)\end{array}$ & $\begin{array}{l}0.995 \\
(0.023)\end{array}$ \\
\hline Int. 2013 and \% HH Syr. & $\begin{array}{l}0.980 \\
(0.023)\end{array}$ & $\begin{array}{l}0.973 \\
(0.022)\end{array}$ \\
\hline Int. 2014 and \% HH Syr. & $\begin{array}{l}1.020 \\
(0.018)\end{array}$ & $\begin{array}{l}1.007 \\
(0.016)\end{array}$ \\
\hline
\end{tabular}




\begin{tabular}{cll} 
Int. 2015 and \% HH Syr. & 1.008 & 0.993 \\
& $(0.021)$ & $(0.019)$ \\
Int. 2016 and \% HH Syr. & 1.021 & 1.014 \\
& $(0.013)$ & $(0.013)$ \\
\hline Controls & & X \\
N (Person-year obs.) & 10594 & 10300 \\
\hline
\end{tabular}

Source: Authors’ calculations based on JLMPS 2016

Notes: ${ }^{*} \mathrm{p}<0.05 ; * * \mathrm{p}<0.01 ; * * * \mathrm{p}<0.001$

Controls include education level, mother's education level, father's education level, father's employment status, age, and age squared

Standard errors (in parentheses) clustered at the locality level 


\section{Appendix J: Instrumenting for potential endogenous placement of refugees}

As an additional robustness check for the potentially endogenous location decisions of refugees, we estimate two-stage least squares (2SLS) models, instrumenting for the locality share of Syrians, based on two different instruments. The first instrument uses the 2004 population census to calculate the percentage of households that are Syrian and Egyptian in a locality in 2004. ${ }^{3}$ This is essentially an "ethnic enclave" approach, using historical shares of ethnic groups to instrument for new arrivals, since new immigrants tend to migrate towards existing communities (Bagir 2017; Card 2009). Although this instrument is common in the literature, one potential threat to its exogeneity is that Syrians and Egyptians in 2004 were primarily migrant workers, who may have been migrating to economically prosperous areas. Should these areas remain more prosperous at the time of the refugee influx, the exclusion condition may not hold.

The second instrument is the distance, in kilometers, to the locality from Za'atari refugee camp, Jordan's largest camp. ${ }^{4}$ While most Syrians are living in host communities, around a fifth pass through refugee camps before arriving in host communities (Krafft et al. 2018). Za'atari refugee camp was opened in July 2012 in response to the rising refugee influx, and located in the desert near the Syrian border. Its placement was unrelated to local labor market conditions, making it a plausibly exogenous instrument, although the proximity to the border, and thus conflict may make areas closer to Za'atari predisposed to worse outcomes regardless of the local share of refugees, such that the exclusion condition may not hold. Although there are potential

\footnotetext{
${ }^{3}$ The share of non-Jordanians increased between 2004 and 2010, driven primarily by economic migrants. We tested using the 2004 share of Syrians only, but found it to be a weak instrument. Since both Syrians and Egyptians pre-2011 would have been relatively substitutable economic migrants, we use the combination as our instrument.

${ }^{4}$ Distance based on Google Maps. Distance to rural localities was not available, so for such missing cases, the average sub-district distance was used. There are very few Syrians — and not many Jordanians either-living in rural areas (Assaad, Krafft, and Keo 2018; Krafft et al. 2018).
} 
threats to the exclusion of each instrument, they are likely to be biased in opposite directions, with the 2004 census Syrians and Egyptians linked to economic opportunity and the distance to the border linked to economic downturn. Thus, we present both instruments separately. We consider the instrumental variable estimates primarily as an additional robustness check, identifying off of alternative assumptions to the difference-in-difference model. Since our instruments are at the locality level, we cannot include locality fixed effects, but do include district fixed effects.

Figure 3 shows the number of households underlying the instrument and the instrument itself for the first instrument, the percentage of households that are Syrian or Egyptian, by subdistrict (the instrument is used on the locality level, which has even more variation). There is clear geographic variation to identify off of, and while visibly correlated with the 2015 share of households Syrian, this instrument also has a distinct pattern, concentrated in the center of the country, relative to identifying off of distance from the Za'atari refugee camp, near the border. 
Figure 3. Number and percentage of households that are Syrian or Egyptian, by subdistrict, 2004 Census
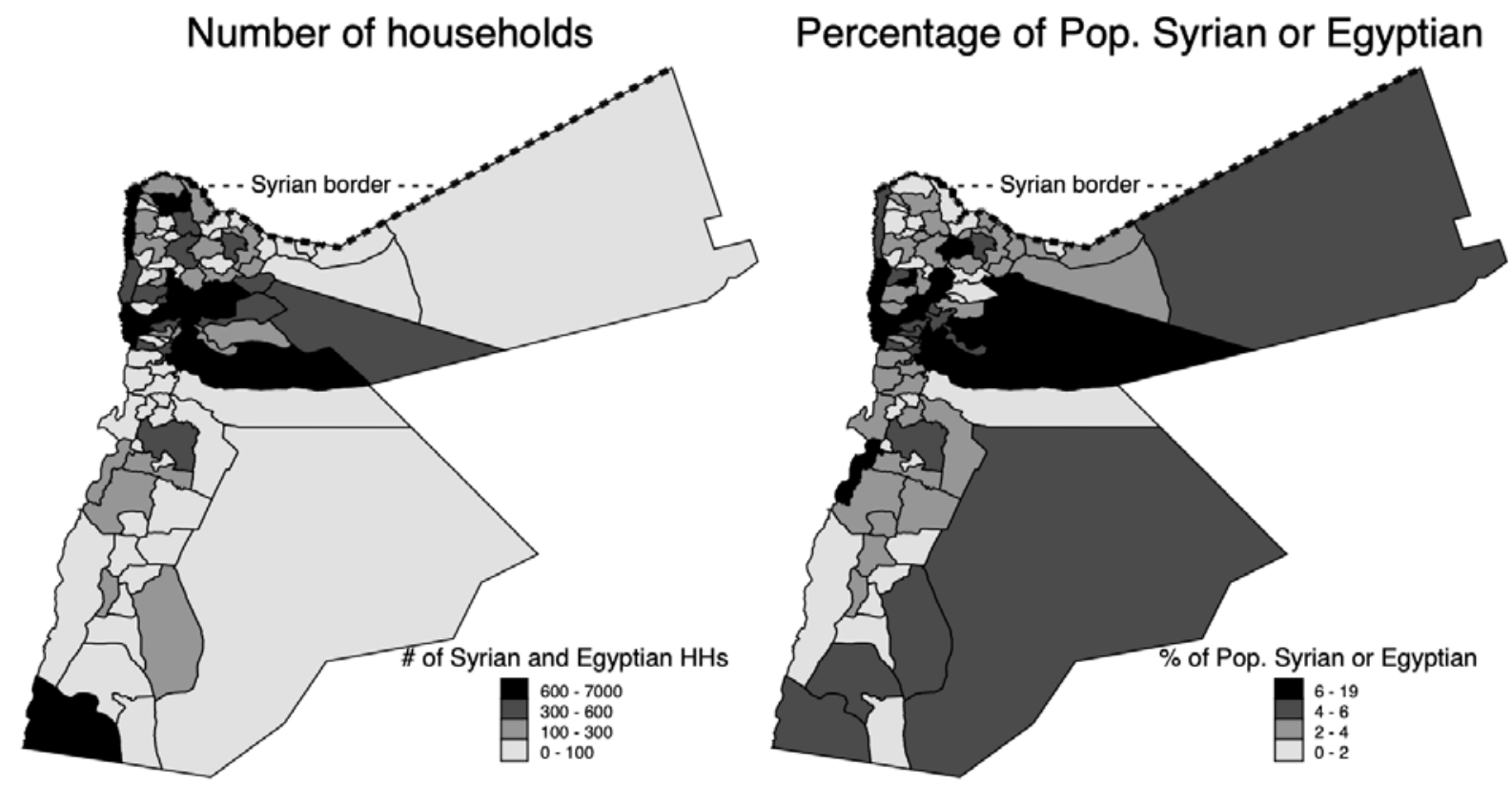

Source: Authors’ calculation based on Census 2004

The first stage and second stage for both instruments are presented in Table 24 (the first stage showing the samples for the different outcomes, not the outcomes themselves). The instruments are significant and sufficiently strong for the 2004 census instrument. F-statistics range from 13.8 (for employment/unemployment samples) to 19.0 (for monthly wages sample). The sign on the instrument is positive, as expected, indicating that as the share of Syrians and Egyptians in 2004 increases, so too does the share in 2015. The second stage of the 2SLS estimates with the 2004 census instrument are all consistently insignificant, showing no significant impact of more Syrians locally. 
The instruments are consistently significant, but weak, for the distance instrument. Fstatistics range from 4.4 (for employment/unemployment samples) to 6.0 (for monthly wages sample). The sign on the instrument is negative, as expected, indicating that each additional kilometer from Za'atari reduces the percentage of households that are Syrian. The second stage of the 2SLS estimates are consistently insignificant. 
Table 24. Instrumental variables 2SLS models, men

\begin{tabular}{|c|c|c|c|c|c|c|c|c|c|c|}
\hline & & & & Ln (hourly & Hours per & Ln (monthl & $\frac{\text { Managerial/ }}{\text { yrofessional }}$ & & $\begin{array}{l}\text { Health and } \\
\underline{\text { Human }}\end{array}$ & Private \\
\hline & \multicolumn{2}{|c|}{ UnemployedEmployed } & Formal & wage) & week & wage) & Occupation & Open sector & Serv. & sector \\
\hline \multicolumn{11}{|c|}{ First stage: 2004 census \% Syr. \& Eg. } \\
\hline $\begin{array}{l}\text { Percentage of HH Syr. } \\
\text { or Eg. in } 2004\end{array}$ & $\begin{array}{l}0.305^{* * *} \\
(0.082)\end{array}$ & $\begin{array}{l}0.305 * * * \\
(0.082)\end{array}$ & $\begin{array}{l}0.396 * * * \\
(0.093)\end{array}$ & $\begin{array}{l}0.390 * * * \\
(0.092)\end{array}$ & $\begin{array}{l}0.391 * * * \\
(0.095)\end{array}$ & $\begin{array}{l}0.393 * * * \\
(0.090)\end{array}$ & $\begin{array}{l}0.382 * * * \\
(0.091)\end{array}$ & $\begin{array}{l}0.380 * * * \\
(0.091)\end{array}$ & $\begin{array}{l}0.380 * * * \\
(0.091)\end{array}$ & $\begin{array}{l}0.386 * * * \\
(0.092)\end{array}$ \\
\hline Controls & $\mathrm{X}$ & $\mathrm{X}$ & $\mathrm{X}$ & $\mathrm{X}$ & $\mathrm{X}$ & $\mathrm{X}$ & $\mathrm{X}$ & $\mathrm{X}$ & $\mathrm{X}$ & $\mathrm{X}$ \\
\hline N (Obs.) & 8024 & 8024 & 4431 & 3591 & 4258 & 3696 & 4418 & 4418 & 4418 & 4464 \\
\hline R-sq. & 0.649 & 0.649 & 0.657 & 0.685 & 0.659 & 0.681 & 0.654 & 0.654 & 0.654 & 0.656 \\
\hline F-stat & 13.776 & 13.776 & 17.975 & 18.036 & 17.060 & 18.978 & 17.697 & 17.588 & 17.588 & 17.648 \\
\hline p-val. & 0.000 & 0.000 & 0.000 & 0.000 & 0.000 & 0.000 & 0.000 & 0.000 & 0.000 & 0.000 \\
\hline
\end{tabular}

Second stage: 2004 census \% Syr. \& Eg.

Percentage HH Syrian

Percentage of $\mathrm{HH}$

\begin{tabular}{|c|c|c|c|c|c|c|c|c|c|c|}
\hline Syr. & $\begin{array}{l}-0.004 \\
(0.004)\end{array}$ & $\begin{array}{l}-0.005 \\
(0.008)\end{array}$ & $\begin{array}{l}0.000 \\
(0.007) \\
\end{array}$ & $\begin{array}{l}0.004 \\
(0.017) \\
\end{array}$ & $\begin{array}{l}0.169 \\
(0.273) \\
\end{array}$ & $\begin{array}{l}0.007 \\
(0.012) \\
\end{array}$ & $\begin{array}{l}0.008 \\
(0.005)\end{array}$ & $\begin{array}{l}0.009 \\
(0.006)\end{array}$ & $\begin{array}{l}0.004 \\
(0.005) \\
\end{array}$ & $\begin{array}{l}0.005 \\
(0.006) \\
\end{array}$ \\
\hline Controls & $\mathrm{X}$ & $\mathrm{X}$ & $\mathrm{X}$ & $\mathrm{X}$ & $\mathrm{X}$ & $\mathrm{X}$ & $\mathrm{X}$ & $\mathrm{X}$ & $\mathrm{X}$ & $\mathrm{X}$ \\
\hline N (Obs.) & 8024 & 8024 & 4431 & 3591 & 4258 & 3696 & 4418 & 4418 & 4418 & 4464 \\
\hline R-sq. & 0.039 & 0.297 & 0.169 & 0.142 & 0.056 & 0.126 & 0.567 & 0.107 & 0.173 & 0.260 \\
\hline
\end{tabular}

\section{First stage: distance to camp}

\begin{tabular}{|c|c|c|c|c|c|c|c|c|c|c|}
\hline $\begin{array}{l}\text { Za'atari Camp } \\
\text { (distance in } \mathbf{k m} \text {.) }\end{array}$ & $\begin{array}{l}-0.057 * \\
(0.027)\end{array}$ & $\begin{array}{l}-0.057 * \\
(0.027)\end{array}$ & $\begin{array}{l}-0.072 * \\
(0.031)\end{array}$ & $\begin{array}{l}-0.073 * \\
(0.030)\end{array}$ & $\begin{array}{l}-0.074 * \\
(0.031)\end{array}$ & $\begin{array}{l}-0.072 * \\
(0.030)\end{array}$ & $\begin{array}{l}-0.072 * \\
(0.031)\end{array}$ & $\begin{array}{l}-0.073 * \\
(0.031)\end{array}$ & $\begin{array}{l}-0.073 * \\
(0.031)\end{array}$ & $\begin{array}{l}-0.071 * \\
(0.031)\end{array}$ \\
\hline Controls & $\mathrm{X}$ & $\mathrm{X}$ & $\mathrm{X}$ & $\mathrm{X}$ & $\mathrm{X}$ & $\mathrm{X}$ & $\mathrm{X}$ & $\mathrm{X}$ & $\mathrm{X}$ & $\mathrm{X}$ \\
\hline N (Obs.) & 8026 & 8026 & 4432 & 3592 & 4259 & 3697 & 4419 & 4419 & 4419 & 4465 \\
\hline R-sq. & 0.636 & 0.636 & 0.641 & 0.670 & 0.644 & 0.664 & 0.639 & 0.639 & 0.639 & 0.641 \\
\hline F-stat & 4.436 & 4.436 & 5.301 & 5.952 & 5.566 & 5.844 & 5.290 & 5.517 & 5.517 & 5.259 \\
\hline p-val. & 0.036 & 0.036 & 0.022 & 0.015 & 0.019 & 0.016 & 0.022 & 0.019 & 0.019 & 0.022 \\
\hline \multicolumn{11}{|c|}{ Second stage: distance to camp } \\
\hline \multicolumn{11}{|c|}{$\begin{array}{l}\text { Percentage HH Syrian } \\
\text { Percentage of HH }\end{array}$} \\
\hline Syr. & $\begin{array}{l}0.006 \\
(0.009)\end{array}$ & $\begin{array}{l}-0.002 \\
(0.012)\end{array}$ & $\begin{array}{l}0.007 \\
(0.015)\end{array}$ & $\begin{array}{l}-0.056 \\
(0.052)\end{array}$ & $\begin{array}{l}0.105 \\
(0.747) \\
\end{array}$ & $\begin{array}{l}-0.038 \\
(0.025)\end{array}$ & $\begin{array}{l}0.013 \\
(0.008)\end{array}$ & $\begin{array}{l}0.023 \\
(0.015)\end{array}$ & $\begin{array}{l}0.003 \\
(0.010)\end{array}$ & $\begin{array}{l}-0.005 \\
(0.013) \\
\end{array}$ \\
\hline Controls & $\mathrm{X}$ & $\mathrm{X}$ & $\mathrm{X}$ & $\mathrm{X}$ & $\mathrm{X}$ & $\mathrm{X}$ & $\mathrm{X}$ & $\mathrm{X}$ & $\mathrm{X}$ & $\mathrm{X}$ \\
\hline N (Obs.) & 8026 & 8026 & 4432 & 3592 & 4259 & 3697 & 4419 & 4419 & 4419 & 4465 \\
\hline R-sq. & 0.031 & 0.299 & 0.166 & 0.059 & 0.057 & 0.063 & 0.557 & 0.055 & 0.174 & 0.268 \\
\hline
\end{tabular}


Source: Authors’ calculations based on JLMPS 2016

Notes: ${ }^{*} \mathrm{p}<0.05 ; * * \mathrm{p}<0.01 ; * * * \mathrm{p}<0.001$

Controls include district fixed effects, education level, mother's education level, father's education level, father's employment status, age, and age squared

Standard errors (in parentheses) clustered at the locality level 
As a further investigation of the validity of our instruments, we explored whether there were pretrends (prior to 2011) that might relate these instruments and labor market outcomes. We undertake these using the retrospective data, for men, presenting the results in Table 25 and Table 26. There is some potential evidence of pre-trends with significant interactions for earlier years compared to 2010 for employment with the percentage Syrian and Egyptian in 2004 instrument, as well as significant negative interactions in terms of health and human services employment. For the Za'atari distance instrument, there are some small significant pre-trends for formality and the private sector. Thus, as we noted, the two instruments may not be excludable, but they are likely to be biased in different directions (e.g. migrant workers going to areas with higher employment rates or effects of being near the Syrian border). 
Table 25. Instrument pre-trends for percentage Syrian or Egyptian in 2004 census (linear probability model), men, retrospective data, 2004-2010

\begin{tabular}{|c|c|c|c|c|c|c|c|}
\hline & Unemployed & Employed & Formal & $\frac{\frac{\text { Managerial/ }}{\text { Professional }}}{\text { Occupation }}$ & Open sector & $\begin{array}{l}\text { Health and } \\
\text { Human } \\
\text { Serv. }\end{array}$ & $\begin{array}{l}\text { Private } \\
\text { sector }\end{array}$ \\
\hline Percentage of HH Syr. or Eg. in 2004 & $\begin{array}{l}-0.000 \\
(0.001)\end{array}$ & $\begin{array}{l}0.002 \\
(0.002)\end{array}$ & $\begin{array}{l}-0.002 \\
(0.003)\end{array}$ & $\begin{array}{l}0.002 \\
(0.002)\end{array}$ & $\begin{array}{l}0.007 * * \\
(0.002)\end{array}$ & $\begin{array}{l}0.002 \\
(0.001)\end{array}$ & $\begin{array}{l}0.006 * \\
(0.002)\end{array}$ \\
\hline \multicolumn{8}{|l|}{ Year (2010 omit.) } \\
\hline 2004 & $\begin{array}{l}0.000 \\
(0.009)\end{array}$ & $\begin{array}{l}-0.008 \\
(0.013)\end{array}$ & $\begin{array}{l}-0.035^{* *} \\
(0.012)\end{array}$ & $\begin{array}{l}0.004 \\
(0.008)\end{array}$ & $\begin{array}{l}0.004 \\
(0.008)\end{array}$ & $\begin{array}{l}0.012 \\
(0.008)\end{array}$ & $\begin{array}{l}0.001 \\
(0.012)\end{array}$ \\
\hline 2005 & $\begin{array}{l}0.002 \\
(0.008)\end{array}$ & $\begin{array}{l}-0.006 \\
(0.012)\end{array}$ & $\begin{array}{l}-0.027^{*} \\
(0.011)\end{array}$ & $\begin{array}{l}0.005 \\
(0.007)\end{array}$ & $\begin{array}{l}0.002 \\
(0.007)\end{array}$ & $\begin{array}{l}0.010 \\
(0.008)\end{array}$ & $\begin{array}{l}0.001 \\
(0.011)\end{array}$ \\
\hline 2006 & $\begin{array}{l}-0.000 \\
(0.007)\end{array}$ & $\begin{array}{l}-0.005 \\
(0.010)\end{array}$ & $\begin{array}{l}-0.023^{*} \\
(0.009)\end{array}$ & $\begin{array}{l}0.004 \\
(0.006)\end{array}$ & $\begin{array}{l}-0.001 \\
(0.007)\end{array}$ & $\begin{array}{l}0.009 \\
(0.007)\end{array}$ & $\begin{array}{l}0.001 \\
(0.008)\end{array}$ \\
\hline 2007 & $\begin{array}{l}-0.003 \\
(0.006)\end{array}$ & $\begin{array}{l}0.006 \\
(0.008)\end{array}$ & $\begin{array}{l}-0.015 \\
(0.008)\end{array}$ & $\begin{array}{l}0.007 \\
(0.005)\end{array}$ & $\begin{array}{l}-0.007 \\
(0.006)\end{array}$ & $\begin{array}{l}0.009 \\
(0.006)\end{array}$ & $\begin{array}{l}-0.006 \\
(0.008)\end{array}$ \\
\hline 2008 & $\begin{array}{l}0.003 \\
(0.006)\end{array}$ & $\begin{array}{l}-0.003 \\
(0.005)\end{array}$ & $\begin{array}{l}-0.002 \\
(0.007)\end{array}$ & $\begin{array}{l}0.004 \\
(0.005)\end{array}$ & $\begin{array}{l}-0.012 \\
(0.007)\end{array}$ & $\begin{array}{l}0.009 \\
(0.005)\end{array}$ & $\begin{array}{l}-0.007 \\
(0.008)\end{array}$ \\
\hline 2009 & $\begin{array}{l}0.005 \\
(0.004)\end{array}$ & $\begin{array}{l}-0.007 \\
(0.005)\end{array}$ & $\begin{array}{l}-0.004 \\
(0.006)\end{array}$ & $\begin{array}{l}0.001 \\
(0.004)\end{array}$ & $\begin{array}{l}-0.005 \\
(0.005)\end{array}$ & $\begin{array}{l}0.003 \\
(0.004)\end{array}$ & $\begin{array}{l}-0.005 \\
(0.005)\end{array}$ \\
\hline \multicolumn{8}{|l|}{ Int. Year and \% of HH Syr. or Eg. in 2004} \\
\hline 2004 \# Percentage of HH Syr. or Eg. in 2004 & $\begin{array}{l}0.001 \\
(0.001)\end{array}$ & $\begin{array}{l}-0.003 * \\
(0.001)\end{array}$ & $\begin{array}{l}0.001 \\
(0.001)\end{array}$ & $\begin{array}{l}-0.001 \\
(0.002)\end{array}$ & $\begin{array}{l}0.000 \\
(0.001)\end{array}$ & $\begin{array}{l}-0.002 \\
(0.001)\end{array}$ & $\begin{array}{l}0.002 \\
(0.001)\end{array}$ \\
\hline 2005 \# Percentage of HH Syr. or Eg. in 2004 & $\begin{array}{l}0.001 \\
(0.001)\end{array}$ & $\begin{array}{l}-0.003^{*} \\
(0.001)\end{array}$ & $\begin{array}{l}0.001 \\
(0.001)\end{array}$ & $\begin{array}{l}-0.001 \\
(0.002)\end{array}$ & $\begin{array}{l}0.001 \\
(0.001)\end{array}$ & $\begin{array}{l}-0.002 \\
(0.001)\end{array}$ & $\begin{array}{l}0.002 \\
(0.001)\end{array}$ \\
\hline 2006 \# Percentage of HH Syr. or Eg. in 2004 & $\begin{array}{l}0.001 \\
(0.001)\end{array}$ & $\begin{array}{l}-0.002 \\
(0.002)\end{array}$ & $\begin{array}{l}0.001 \\
(0.001)\end{array}$ & $\begin{array}{l}-0.000 \\
(0.001)\end{array}$ & $\begin{array}{l}0.001 \\
(0.001)\end{array}$ & $\begin{array}{l}-0.002 * \\
(0.001)\end{array}$ & $\begin{array}{l}0.002 \\
(0.001)\end{array}$ \\
\hline 2007 \# Percentage of HH Syr. or Eg. in 2004 & $\begin{array}{l}0.001 \\
(0.001)\end{array}$ & $\begin{array}{l}-0.003 * \\
(0.001)\end{array}$ & $\begin{array}{l}0.000 \\
(0.001)\end{array}$ & $\begin{array}{l}-0.001 \\
(0.001)\end{array}$ & $\begin{array}{l}0.001 \\
(0.001)\end{array}$ & $\begin{array}{l}-0.002 * \\
(0.001)\end{array}$ & $\begin{array}{l}0.002 \\
(0.001)\end{array}$ \\
\hline 2008 \# Percentage of HH Syr. or Eg. in 2004 & $\begin{array}{l}0.001 \\
(0.001)\end{array}$ & $\begin{array}{l}-0.001 \\
(0.001)\end{array}$ & $\begin{array}{l}-0.001 \\
(0.001)\end{array}$ & $\begin{array}{l}-0.001 \\
(0.001)\end{array}$ & $\begin{array}{l}0.001 \\
(0.001)\end{array}$ & $\begin{array}{l}-0.002^{* *} \\
(0.001)\end{array}$ & $\begin{array}{l}0.001 \\
(0.001)\end{array}$ \\
\hline 2009 \# Percentage of HH Syr. or Eg. in 2004 & $\begin{array}{l}0.000 \\
(0.001)\end{array}$ & $\begin{array}{l}-0.001 \\
(0.001)\end{array}$ & $\begin{array}{l}0.000 \\
(0.001)\end{array}$ & $\begin{array}{l}-0.000 \\
(0.001)\end{array}$ & $\begin{array}{l}0.000 \\
(0.001)\end{array}$ & $\begin{array}{l}-0.002 * \\
(0.001)\end{array}$ & $\begin{array}{l}0.000 \\
(0.001)\end{array}$ \\
\hline
\end{tabular}




\begin{tabular}{|c|c|c|c|c|c|c|c|}
\hline $\mathrm{N}$ & 41642 & 41642 & 21632 & 21486 & 21517 & 21517 & 21632 \\
\hline R-sq. & 0.047 & 0.250 & 0.153 & 0.567 & 0.140 & 0.162 & 0.272 \\
\hline
\end{tabular}

Source: Authors' calculations based on JLMPS 2016

Notes: ${ }^{*} \mathrm{p}<0.05 ;{ }^{* *} \mathrm{p}<0.01 ;{ }^{* * *} \mathrm{p}<0.001$

Controls include district fixed effects, education level, mother's education level, father's education level, father’s employment status, age, and age squared

Standard errors (in parentheses) clustered at the locality level 
Table 26. Instrument pre-trends for distance to Za'atari (linear probability model), men, retrospective data, $2004-2010$

\begin{tabular}{|c|c|c|c|c|c|c|c|}
\hline & Unemployed & Employed & Formal & $\frac{\text { Managerial/ }}{\text { Professional }}$ & Open sector & $\begin{array}{l}\text { Health and } \\
\text { Human } \\
\text { Serv. }\end{array}$ & $\begin{array}{l}\text { Private } \\
\text { sector }\end{array}$ \\
\hline \multicolumn{8}{|l|}{ Year (2010 omit.) } \\
\hline 2004 & $\begin{array}{l}0.006 \\
(0.011)\end{array}$ & $\begin{array}{l}-0.019 \\
(0.014)\end{array}$ & $\begin{array}{l}-0.050 * * * \\
(0.015)\end{array}$ & $\begin{array}{l}-0.005 \\
(0.008)\end{array}$ & $\begin{array}{l}0.003 \\
(0.010)\end{array}$ & $\begin{array}{l}-0.003 \\
(0.008)\end{array}$ & $\begin{array}{l}0.027 * \\
(0.013)\end{array}$ \\
\hline 2005 & $\begin{array}{l}0.012 \\
(0.009)\end{array}$ & $\begin{array}{l}-0.017 \\
(0.013)\end{array}$ & $\begin{array}{l}-0.041 * * \\
(0.015)\end{array}$ & $\begin{array}{l}-0.004 \\
(0.007)\end{array}$ & $\begin{array}{l}0.008 \\
(0.008)\end{array}$ & $\begin{array}{l}-0.004 \\
(0.007)\end{array}$ & $\begin{array}{l}0.026 * \\
(0.012)\end{array}$ \\
\hline 2006 & $\begin{array}{l}0.006 \\
(0.009)\end{array}$ & $\begin{array}{l}-0.015 \\
(0.012)\end{array}$ & $\begin{array}{l}-0.034^{* *} \\
(0.012)\end{array}$ & $\begin{array}{l}-0.001 \\
(0.006)\end{array}$ & $\begin{array}{l}0.001 \\
(0.008)\end{array}$ & $\begin{array}{l}-0.008 \\
(0.006)\end{array}$ & $\begin{array}{l}0.023^{*} \\
(0.010)\end{array}$ \\
\hline 2007 & $\begin{array}{l}0.005 \\
(0.007)\end{array}$ & $\begin{array}{l}-0.010 \\
(0.009)\end{array}$ & $\begin{array}{l}-0.022 * \\
(0.009)\end{array}$ & $\begin{array}{l}0.005 \\
(0.005)\end{array}$ & $\begin{array}{l}-0.008 \\
(0.008)\end{array}$ & $\begin{array}{l}-0.005 \\
(0.005)\end{array}$ & $\begin{array}{l}0.008 \\
(0.008)\end{array}$ \\
\hline 2008 & $\begin{array}{l}0.010 \\
(0.007)\end{array}$ & $\begin{array}{l}-0.013 \\
(0.007)\end{array}$ & $\begin{array}{l}-0.005 \\
(0.008)\end{array}$ & $\begin{array}{l}-0.001 \\
(0.005)\end{array}$ & $\begin{array}{l}-0.015 \\
(0.008)\end{array}$ & $\begin{array}{l}-0.000 \\
(0.005)\end{array}$ & $\begin{array}{l}0.003 \\
(0.008)\end{array}$ \\
\hline 2009 & $\begin{array}{l}0.008 \\
(0.005)\end{array}$ & $\begin{array}{l}-0.015^{*} \\
(0.006)\end{array}$ & $\begin{array}{l}-0.004 \\
(0.008)\end{array}$ & $\begin{array}{l}-0.002 \\
(0.004)\end{array}$ & $\begin{array}{l}-0.011 \\
(0.007)\end{array}$ & $\begin{array}{l}-0.004 \\
(0.004)\end{array}$ & $\begin{array}{l}-0.001 \\
(0.006)\end{array}$ \\
\hline Za'atari Camp (distance in km.) & $\begin{array}{l}-0.001 \\
(0.001)\end{array}$ & $\begin{array}{l}0.000 \\
(0.001)\end{array}$ & $\begin{array}{l}-0.000 \\
(0.001)\end{array}$ & $\begin{array}{l}-0.000 \\
(0.000)\end{array}$ & $\begin{array}{l}-0.000 \\
(0.001)\end{array}$ & $\begin{array}{l}-0.001 \\
(0.001)\end{array}$ & $\begin{array}{l}0.001 \\
(0.001)\end{array}$ \\
\hline \multicolumn{8}{|c|}{ Int. Year and Za'atari Camp (distance in km.) } \\
\hline 2004 \# Zaatari Camp & $\begin{array}{l}-0.000 \\
(0.000)\end{array}$ & $\begin{array}{l}-0.000 \\
(0.000)\end{array}$ & $\begin{array}{l}0.000 * \\
(0.000)\end{array}$ & $\begin{array}{l}0.000 \\
(0.000)\end{array}$ & $\begin{array}{l}0.000 \\
(0.000)\end{array}$ & $\begin{array}{l}0.000 \\
(0.000)\end{array}$ & $\begin{array}{l}-0.000 * * \\
(0.000)\end{array}$ \\
\hline 2005 \# Zaatari Camp & $\begin{array}{l}-0.000 \\
(0.000)\end{array}$ & $\begin{array}{l}-0.000 \\
(0.000)\end{array}$ & $\begin{array}{l}0.000 \\
(0.000)\end{array}$ & $\begin{array}{l}0.000 \\
(0.000)\end{array}$ & $\begin{array}{l}-0.000 \\
(0.000)\end{array}$ & $\begin{array}{l}0.000 \\
(0.000)\end{array}$ & $\begin{array}{l}-0.000 * * \\
(0.000)\end{array}$ \\
\hline 2006 \# Zaatari Camp & $\begin{array}{l}-0.000 \\
(0.000)\end{array}$ & $\begin{array}{l}-0.000 \\
(0.000)\end{array}$ & $\begin{array}{l}0.000 \\
(0.000)\end{array}$ & $\begin{array}{l}0.000 \\
(0.000)\end{array}$ & $\begin{array}{l}0.000 \\
(0.000)\end{array}$ & $\begin{array}{l}0.000 \\
(0.000)\end{array}$ & $\begin{array}{l}-0.000 * * \\
(0.000)\end{array}$ \\
\hline 2007 \# Zaatari Camp & $\begin{array}{l}-0.000 \\
(0.000)\end{array}$ & $\begin{array}{l}0.000 \\
(0.000)\end{array}$ & $\begin{array}{l}0.000 \\
(0.000)\end{array}$ & $\begin{array}{l}-0.000 \\
(0.000)\end{array}$ & $\begin{array}{l}0.000 \\
(0.000)\end{array}$ & $\begin{array}{l}0.000 \\
(0.000)\end{array}$ & $\begin{array}{l}-0.000 \\
(0.000)\end{array}$ \\
\hline 2008 \# Zaatari Camp & $\begin{array}{l}-0.000 \\
(0.000)\end{array}$ & $\begin{array}{l}0.000 \\
(0.000)\end{array}$ & $\begin{array}{l}0.000 \\
(0.000)\end{array}$ & $\begin{array}{l}0.000 \\
(0.000)\end{array}$ & $\begin{array}{l}0.000 \\
(0.000)\end{array}$ & $\begin{array}{l}-0.000 \\
(0.000)\end{array}$ & $\begin{array}{l}-0.000 \\
(0.000)\end{array}$ \\
\hline 2009 \# Zaatari Camp & $\begin{array}{l}-0.000 \\
(0.000)\end{array}$ & $\begin{array}{l}0.000 \\
(0.000)\end{array}$ & $\begin{array}{l}0.000 \\
(0.000)\end{array}$ & $\begin{array}{l}0.000 \\
(0.000)\end{array}$ & $\begin{array}{l}0.000 \\
(0.000)\end{array}$ & $\begin{array}{l}-0.000 \\
(0.000)\end{array}$ & $\begin{array}{l}-0.000 \\
(0.000)\end{array}$ \\
\hline $\mathrm{N}$ & 41649 & 41649 & 21632 & 21486 & 21517 & 21517 & 21632 \\
\hline R-sq. & 0.049 & 0.250 & 0.153 & 0.567 & 0.137 & 0.163 & 0.270 \\
\hline
\end{tabular}


Source: Authors' calculations based on JLMPS 2016

Notes: ${ }^{*} \mathrm{p}<0.05 ;{ }^{* *} \mathrm{p}<0.01 ;{ }^{* * *} \mathrm{p}<0.001$

Controls include district fixed effects, education level, mother's education level, father's education level, father's employment status, age, and age squared

Standard errors (in parentheses) clustered at the locality level 


\section{Appendix K: Varying levels of geographic aggregation}

This appendix investigates the sensitivity of our results to varying the level of geographic aggregation (sub-district or district rather than locality). We focus here on our main sample, panel data for men. Appendix D, which presents the repeated cross-section data, is also an analysis identifying off of variation in the share Syrian at the sub-district level. Before presenting the model results, we discuss the degree of variation in localities within sub-districts or districts. Overall, among Jordanians aged 15-64 (our sample), the median share of households Syrian in their locality is $9.6 \%$, with a standard deviation of 7.1 percentage points. Within sub-districts, the average standard deviation of locality-level percentage of households Syrian was 3.5 percentage points, while within districts the average standard deviation of locality-level percentage of households Syrian was 3.7 percentage points. This suggests variation across localities within sub-districts and districts, but also, unsurprisingly, correlation within districts and sub-districts and less variation than nationally.

Table 27 presents results of the panel data models for men using sub-district share of households Syrian while Table 28 presents results with district share of households Syrian. In both cases, results are similar to the main locality measures, although, unsurprisingly, statistical significance is lost due for some results due to higher levels of aggregation (and clustering of standard errors). 
Table 27. Sub-district share of households Syrian: Labor market outcomes (fixed effects linear probability and OLS models), men, panel data

\begin{tabular}{|c|c|c|c|c|c|c|c|c|c|c|}
\hline & Unemployed & Employed & Formal & $\begin{array}{l}\text { Ln (hourly } \\
\text { wage) }\end{array}$ & $\begin{array}{l}\text { Hours per } \\
\text { week }\end{array}$ & $\begin{array}{l}\text { Ln (monthly } \\
\text { wage) }\end{array}$ & $\frac{\text { Managerial/ }}{\text { Professional }}$ & Open sector & $\begin{array}{l}\text { Health and } \\
\text { Human } \\
\text { Serv. }\end{array}$ & Private sector \\
\hline \multicolumn{11}{|l|}{ Year (2010 omit.) } \\
\hline 2016 & $\begin{array}{l}0.040 \\
(0.036)\end{array}$ & $\begin{array}{l}-0.091 \\
(0.057)\end{array}$ & $\begin{array}{l}0.157 * * * \\
(0.032)\end{array}$ & $\begin{array}{l}0.397 * * \\
(0.117)\end{array}$ & $\begin{array}{l}-3.101^{*} \\
(1.304)\end{array}$ & $\begin{array}{l}0.145 \\
(0.112)\end{array}$ & $\begin{array}{l}0.019 \\
(0.026)\end{array}$ & $\begin{array}{l}-0.004 \\
(0.029)\end{array}$ & $\begin{array}{l}-0.006 \\
(0.016)\end{array}$ & $\begin{array}{l}-0.018 \\
(0.033)\end{array}$ \\
\hline \multicolumn{11}{|l|}{$\begin{array}{l}\text { Int. year and \% HH } \\
\text { Syrian } \\
\text { Int. } 2016 \text { and \% HH }\end{array}$} \\
\hline Syr. & $\begin{array}{l}-0.000 \\
(0.001) \\
\end{array}$ & $\begin{array}{l}0.001 \\
(0.001)\end{array}$ & $\begin{array}{l}0.002 \\
(0.001)\end{array}$ & $\begin{array}{l}0.004 \\
(0.002) \\
\end{array}$ & $\begin{array}{l}-0.077 \\
(0.096) \\
\end{array}$ & $\begin{array}{l}0.002 \\
(0.003) \\
\end{array}$ & $\begin{array}{l}0.001 \\
(0.001)\end{array}$ & $\begin{array}{l}0.001 \\
(0.001)\end{array}$ & $\begin{array}{l}-0.000 \\
(0.001)\end{array}$ & $\begin{array}{l}-0.001 \\
(0.001)\end{array}$ \\
\hline $\mathbf{N}$ & 7363 & 7394 & 4786 & 3863 & 4677 & 3924 & 4788 & 4789 & 4789 & 4808 \\
\hline
\end{tabular}

Source: Authors' calculations based on JLMPS 2010 - JLMPS 2016 panel

Notes: ${ }^{*} \mathrm{p}<0.05 ;{ }^{* *} \mathrm{p}<0.01 ;{ }^{* * *} \mathrm{p}<0.001$

Controlling for age and age squared in year

Standard errors (in parentheses) clustered at the sub-district level 
Table 28. District share of households Syrian: Labor market outcomes (fixed effects linear probability and OLS models), men, panel data

\begin{tabular}{|c|c|c|c|c|c|c|c|c|c|c|}
\hline & Unemployed & Employed & Formal & $\begin{array}{l}\text { Ln (hourly } \\
\text { wage) }\end{array}$ & $\begin{array}{l}\text { Hours per } \\
\text { week }\end{array}$ & $\begin{array}{l}\text { Ln (monthly } \\
\text { wage) }\end{array}$ & $\frac{\text { Managerial/ }}{\text { Professional }}$ & Open sector & $\begin{array}{l}\text { Health and } \\
\text { Human } \\
\text { Serv. }\end{array}$ & $\begin{array}{l}\text { Private } \\
\text { sector }\end{array}$ \\
\hline \multicolumn{11}{|l|}{ Year (2010 omit.) } \\
\hline 2016 & $\begin{array}{l}0.041 \\
(0.038)\end{array}$ & $\begin{array}{l}-0.086 \\
(0.061)\end{array}$ & $\begin{array}{l}0.150 * * * \\
(0.034)\end{array}$ & $\begin{array}{l}0.395 * * \\
(0.121)\end{array}$ & $\begin{array}{l}-3.339 * \\
(1.632)\end{array}$ & $\begin{array}{l}0.157 \\
(0.111)\end{array}$ & $\begin{array}{l}0.021 \\
(0.027)\end{array}$ & $\begin{array}{l}-0.007 \\
(0.030)\end{array}$ & $\begin{array}{l}-0.018 \\
(0.018)\end{array}$ & $\begin{array}{l}-0.009 \\
(0.034)\end{array}$ \\
\hline \multicolumn{11}{|l|}{$\begin{array}{l}\text { Int. year and \% HH } \\
\text { Syrian } \\
\quad \text { Int. } 2016 \text { and \% HH }\end{array}$} \\
\hline Syr. & $\begin{array}{l}-0.000 \\
(0.001) \\
\end{array}$ & $\begin{array}{l}0.001 \\
(0.002)\end{array}$ & $\begin{array}{l}0.003^{*} \\
(0.001) \\
\end{array}$ & $\begin{array}{l}0.004 \\
(0.003) \\
\end{array}$ & $\begin{array}{l}-0.054 \\
(0.130) \\
\end{array}$ & $\begin{array}{l}0.001 \\
(0.004) \\
\end{array}$ & $\begin{array}{l}0.001 \\
(0.001) \\
\end{array}$ & $\begin{array}{l}0.001 \\
(0.001) \\
\end{array}$ & $\begin{array}{l}0.001 \\
(0.001) \\
\end{array}$ & $\begin{array}{l}-0.002 \\
(0.001) \\
\end{array}$ \\
\hline $\mathbf{N}$ & 7363 & 7394 & 4786 & 3863 & 4677 & 3924 & 4788 & 4789 & 4789 & 4808 \\
\hline
\end{tabular}

Source: Authors' calculations based on JLMPS 2010 - JLMPS 2016 panel

Notes: ${ }^{*} \mathrm{p}<0.05 ;{ }^{* *} \mathrm{p}<0.01 ; * * * \mathrm{p}<0.001$

Controlling for age and age squared in year

Standard errors (in parentheses) clustered at the district level 


\section{Appendix L: New schools and labor demand in education}

One potential mechanism for refugees creating labor demand is through use of health and human services, such as education. Education for Syrians is supported, financially, through both donor aid and government funds (Brussels II Conference 2018). For example, in May $2016 \$ 81.5$ million was pledged specifically for education (Human Rights Watch 2016). In this appendix we explore the potential role for such labor demand in the labor market in Jordan, examining the role of new schools and new shifts in Jordan. In host communities, Syrians can enroll in public schools. If there are spots available in existing schools, after Jordanians have enrolled, Syrians can take those spots; otherwise a second shift is added to schools. As of the 2016-2017 school year, there were 209 schools on double shifts and 45 schools providing education to refugee children in camps with Jordanian teaching staff (Ministry of Planning and International Cooperation 2017). Donors, such as USAID, have helped finance expanding or renovating schools as well as building new schools. Both the second shifts and additional schools have hired additional teachers (Human Rights Watch 2016).

As a potential mechanism for creating labor demand, we use data on new schools. In the Education Management Information System (EMIS) data from 2016/17, ${ }^{5}$ an observation is a shift within a school (so if a school operates two shifts, it has two observations), which is consistent with the fact that a second shift would have additional hiring. We calculate the percentage of observations ("schools," which may be shifts within existing schools) that are “new,” established in 2011 or later based on their establishment date in the EMIS. We calculate this measure at the sub-district level, the lowest level of geography available with the EMIS. We

\footnotetext{
${ }^{5}$ See Assaad, Ginn, and Saleh (2018) for additional discussion of the EMIS data and analyses of the (non-)effect of Syrians on Jordanians' education outcomes.
} 
interact this variable with the year (2016) in the panel data. The results are presented in Table 29. In areas with more new schools as of 2016, for each percentage point increase in the share of schools that are "new" there is a 0.3 percentage point increase in the probability of employment in the health and human services sector (which includes education). There are not other significant effects. This multivariate evidence aligns with the patterns in Figure 1 in Appendix A, suggesting a shift into such work between 2010 and 2016. 
Table 29. Models including new schools: Labor market outcomes (fixed effects linear probability and OLS models), men, panel data

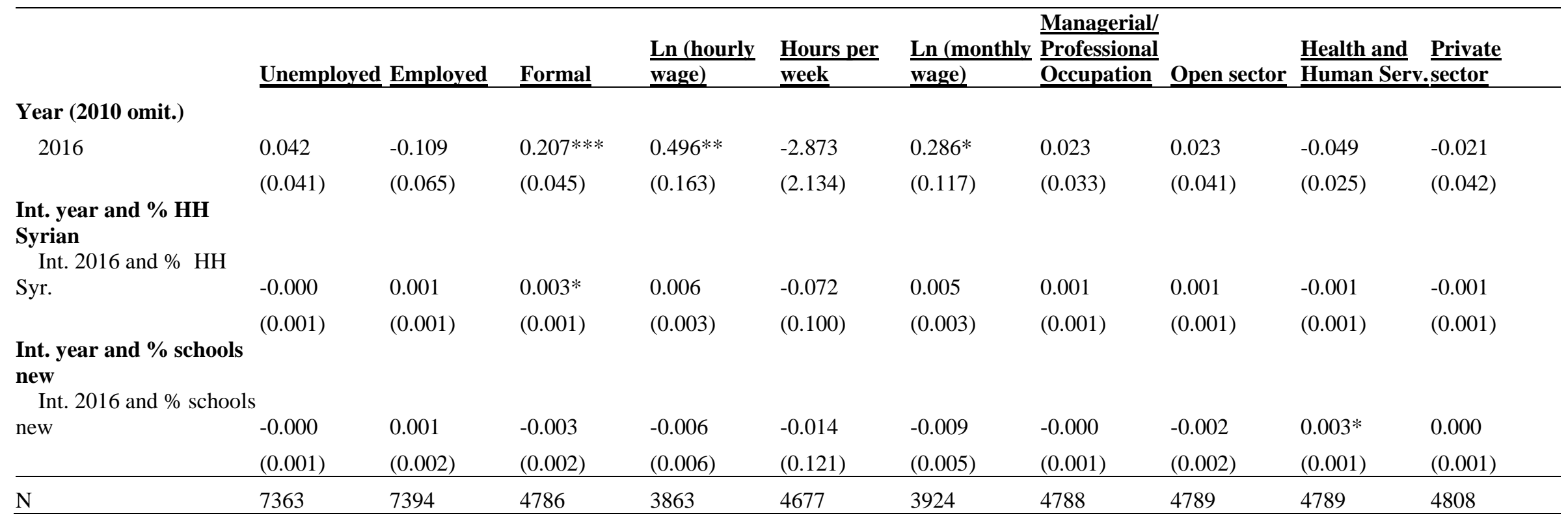

Source: Authors' calculations based on JLMPS 2010 - JLMPS 2016 panel

Notes: ${ }^{*} \mathrm{p}<0.05 ;{ }^{* *} \mathrm{p}<0.01 ;{ }^{* * *} \mathrm{p}<0.001$

Controlling for age and age squared in year

Standard errors (in parentheses) clustered at the sub-district level 


\section{Appendices References}

Amer, Mona. 2014. “The School-to-Work Transition of Jordanian Youth.” In The Jordanian Labour Market in the New Millenium, edited by Ragui Assaad. Oxford, UK: Oxford University Press.

Assaad, Ragui, Thomas Ginn, and Mohamed Saleh. 2018. "Impact of Syrian Refugees in Jordan on Education Outcomes for Jordanian Youth.” Economic Research Forum Working Paper Series No. 1214. Cairo, Egypt.

Assaad, Ragui, and Caroline Krafft. 2016. "Labor Market Dynamics and Youth Unemployment in the Middle East and North Africa: Evidence from Egypt, Jordan and Tunisia.” Economic Research Forum Working Paper Series No. 993. Cairo, Egypt.

Assaad, Ragui, Caroline Krafft, and Caitlyn Keo. 2018. “The Composition of Labor Supply and Its Evolution from 2010 to 2016 in Jordan.” Economic Research Forum Working Paper Series No. 1183. Cairo, Egypt.

Bagir, Yusuf. 2017. "Impact of the Syrian Refugee Influx on Turkish Native Workers: An Ethnic Enclave Approach.” MPRA Paper No. 80803. Munich, Germany.

Brussels II Conference. 2018. "We Made a Promise: Ensuring Learning Pathways and Protection for Syrian Children and Youth.” Brussels.

Card, David. 2009. "Immigration and Inequality.” The American Economic Review 99 (2): 1-21.

Human Rights Watch. 2016. “'We’re Afraid for Their Future’: Barriers to Education for Syrian Refugee Children in Jordan.” New York: Human Rights Watch.

Krafft, Caroline, Maia Sieverding, Colette Salemi, and Caitlyn Keo. 2018. "Syrian Refugees in Jordan: Demographics, Livelihoods, Education, and Health.” Economic Research Forum Working Paper Series No. 1184. Cairo, Egypt.

Ministry of Planning and International Cooperation. 2017. "Jordan Response Plan for the Syria Crisis: 2018-2020.” Amman, Jordan.

Mryyan, Nader. 2014. "Demographics, Labor Force Participation, and Unemployment in Jordan.” In The Jordanian Labour Market in the New Millennium, edited by Ragui Assaad, 39-63. Oxford, UK: Oxford University Press. 